KALISY CABEDA DE SOUZA

\title{
O Sentido se Sente com o Corpo: Reflexões sobre a criação poética a partir do corpo cênico
}

Dissertação de Mestrado apresentada ao Programa de Pós-Graduação em Artes Cênicas do Departamento de Artes Cênicas da Escola de Comunicação e Artes da Universidade de São Paulo, como exigência para obtenção do título de Mestre em Artes Cênicas.

Área de concentração: Texto e Cena Teoria e Prática do Teatro

Orientadora: Profa. Dra. Sayonara Sousa Pereira 
Nome: SOUZA, Kalisy Cabeda de

Número USP: 7958338

Título: O Sentido de Sente com o Corpo: Reflexões sobre a criação poética a partir do corpo cênico

Dissertação de Mestrado apresentada ao Programa de Pós-Graduação em Artes Cênicas do Departamento de Artes Cênicas da Escola de Comunicação e Artes da Universidade de São Paulo, como exigência para obtenção do título de Mestre em Artes Cênicas

Aprovada em:

BANCA EXAMINADORA:

Profa. Dra. Sayonara Sousa Pereira (Escola de Comunicação e Artes/USP) Orientadora e Presidenta da Banca

Profa. Dra. Ana Maria Rodriguez Costas (Instituto de Artes/UNICAMP) Membro Titular

Profa. Dra. Marília Velardi (Escola de Artes Ciências e Humanidades/USP) Membro Titular

Profa. Dra. Maria Helena de Araújo Bastos (Escola de Comunicação e Artes/USP) Membro Suplente

Profa. Dra. Verônica Fabrini (Instituto de Artes/UNICAMP)

Membro Suplente 


\section{AGRADECIMENTOS}

Seriam muitos os agradecimentos a todos aqueles que permitiram iniciar, permanecer e concluir esta pesquisa, mas agradeço aqui a algumas pessoas e instituições que se tornaram fundamentais nesse processo:

- primeiramente, a minha orientadora Profa. Dra. Sayonara Sousa Pereira, que acolheu esta pesquisa, a mim e a minha família nestes dois anos de orientação, trabalho, estudo, dança, encontros, amizade, afetividade, respeito e compreensão;

- à Fundação de Amparo à Pesquisa do Estado de São Paulo (FAPESP), que viabilizou minha bolsa de mestrado e os recursos financeiros que me permitiram pesquisar, estudar e concluir esta dissertação;

- a Sissi Betina Venturin, pelo abrigo, pela amizade, pelo carinho, pelo amor, pela incrível parceria e dedicação a este trabalho, o qual permitiu transformar meus pensamentos e palavras em movimento e gestos;

- a Di Pannacci, pelo companheirismo, pelo encontro de vida e de arte, pelo apoio incondicional a mim e a nossa família, por me ajudar a encontrar os caminhos entre a vida e o trabalho, pela dedicação a este projeto com suas lindas fotos e iluminação e a sua dedicação e empenho ao nosso maior projeto e sentido de nossa vida;

- a Jorge Peña, que através da escuta sensível, artística e poética nos presenteou com sua amizade, presença e com a composição da trilha sonora de nosso exercício cênico;

- aos amigos e familiares que nos acolheram e nos forneceram uma rede apoio para realizar e concluir esta dissertação: Rodrigo Fiatt, Viviana Shames, Airton Tomazzoni, Inês Marocco, Sofia Vilasboas, Evandro Palma, Mandiro, Jaya, Miho, Regiane Ishii, André Liberato, Terezinha e Afonso Pannacci, Rosário, Letícia Chiochetta, Luciana Mazzini e Jonathas Ramos;

- a Rafael Avancini, Carolina Rocha, Gabriel Bitar e Yu Miwa, pelo cartaz, filmagem e fotos de nosso exercício cênico de composição;

- ao Laboratório de Pesquisa e Estudos em Tanz-Theatralidades (LAPETT), em especial à colega Letícia Olivares, pelos encontros, amigos, diálogo e, principalmente, pela dança; 
- ao Grupo Cerco de teatro e ao Grupo Experimental de Dança de Porto Alegre, onde pude vivenciar, estudar e experienciar o teatro e a dança que me permitiram elaborar os primeiros passos dessa dissertação;

- à Banca Examinadora desta dissertação, que também foi Banca do Exame de Qualificação: Profa. Dra. Sayonara Sousa Pereira, Profa. Dra. Ana Maria Rodriguez Costas, Profa. Dra. Marília Velardi, por indicaram e apontarem os caminhos que nos permitiram ampliar nossas percepções sobre a pesquisa de mestrado e a elaboração desta dissertação;

- a Josely Vianna Baptista, pela sua linda e intensa poesia, que dialogou de forma tão sincera com nossas poesias cênicas e nos presenteou com o título tanto de nosso exercício cênico quanto desta dissertação;

- à Universidade de São Paulo, ao Programa de Pós-graduação da ECA e ao Departamento de Artes Cênicas, que forneceram o espaço físico, acadêmico, social e estrutural que permitiram realizar esta pesquisa;

- aos funcionários do Departamento de Artes Cênicas (CAC), em especial ao Fernandes e ao pessoal da cenotécnica e da iluminação, que tanto nos auxiliaram na realização do exercício cênico de composição;

- por fim, ao Gael, sentido maior de minha vida, que veio de presente ao longo dessa dissertação e que me ensina todo dia o que é amar; pela sua generosidade, amor, carinho, paciência, compreensão e alegria!

- e a todos aqueles que de alguma forma colaboram ao longo desses dois anos de pesquisa, de vida e de arte. 


\section{RESUMO}

\section{O Sentido se Sente com o Corpo: Reflexões sobre a criação poética a partir do corpo cênico}

Esta dissertação tem por objetivo refletir sobre a criação poética a partir do corpo cênico. Nossa reflexão está fundamentada na práxis sobre o ato criativo, a percepção e a sensibilidade para a elaboração de um conhecimento através de nossa experiência. Nesse percurso, percebemos o corpo cênico a partir de um diálogo constante entre a dança e o teatro, fundamentando nosso pensamento principalmente nas noções de movimento, corpo e fisicalidade trazidas pelos filósofos José Gil (2004) e Susanne Langer (1980) e pelo crítico Antônio Pinto Ribeiro (1994). Entendemos a práxis como essencial ao desenvolvimento do corpo cênico. Nosso pensamento se funda na elaboração de um estudo experimental sobre o corpo cênico através da práxis sobre alguns princípios presentes no sistema de movimento de Rudolf Von Laban, especificamente os fatores de movimento: peso, espaço, tempo e fluência, e na pedagogia de Jacques Lecoq, sobre a metodologia das transferências. A partir desse estudo, desenvolvemos habilidades técnico-artísticas que nos permitiram reconhecer o material poético e expressivo de cada atriz-bailarina envolvida nesta pesquisa. Após realizar a experiência sobre as metodologias pesquisadas, utilizamos o material corpóreo criativo de cada intérprete na elaboração do exercício cênico de composição: O Sentido se Sente com o Corpo. Através de nosso processo criativo e das noções sobre o corpo cênico, elaboramos nossas reflexões sobre a criação artística fundamentada no corpo e sua fisicalidade singular e poética. Por fim, percebemos que o material corporal de cada atriz-bailarina encontrou, no diálogo entre a dança e o teatro, uma possibilidade de investigação e criação, elaborando uma linguagem artística que encontra seu material poético no corpo cênico.

Palavras-chave: Fisicalidade singular. Corpo cênico. Rudolf Von Laban. Jacques Lecoq. Experiência. Criação poética. 


\section{ABSTRACT \\ The Sense is felt by the body: reflexions about Poetry Creation starting with the cenical body}

The purpose of this dissertation is to reflect about the poetry creation through the cenical body. Our reflexion emerges from the praxis about the creative act, perception and sensibility, aiming the elaboration of a knowledge through our experience. In this experience, we perceived the cenical body as a constant dialogue between dance and theater, grounding our thought mainly on the notions of movement, body and physicality brought by the philosophers José Gil (2004) and Susanne Langer (1980) e by the critic Antonio Pinto Ribeiro (1994). We understand the praxis as essential to the development of the cenical body. Our thought is based in the elaboration of an experimental study about the cenical body though praxis of some principles present in the movement system of Rudolf Von Laban, specifically the movement factors: weight, space, time and fluency, and in the pedagogy of Jacques Lecoq, about the methodology of transferences. Starting with this study, we developed technical-artistic abilities that allowed us to recognize the poetical and expressive material of each dancer-actress involved in this research. After performing the experience about the researched methodologies, we used the creative body material of each interpreter in the elaboration of the cenical composition exercise: The sense is felt by the body. Through our creative process and the notions about the cenical body, we elaborated our reflexions about artistic creation based on the body and its poetical and singular physicality. Finally, we realized that the body material of each dancer-actress found, in the dialogue between dance and theater, a possibility of investigation and creation, elaborating an artistic language that finds its poetical material in the cenical body.

Keywords: Singular Physicality. Cenical body. Rudolf Von Laban. Jacques Lecoq. Experience. Poetical creation. 


\section{LISTA DE IMAGENS}

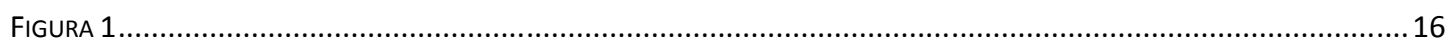

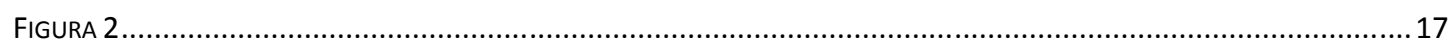

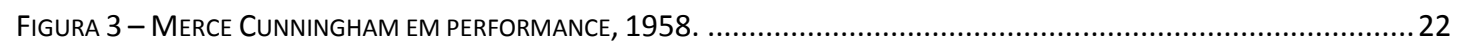

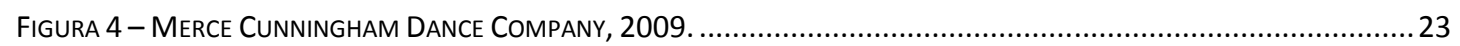

FIGURA 5 - ALUNOS DE LABAN EM EXPERIÊNCIA DE VERÃo SUL DO MONTE VERITÁ. ...................................................... 39

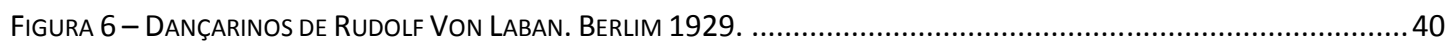

FIGURA 7 - ESTA FIGURA REPRESENTA A CINESFERA ELABORADA POR RUDOLF VON LABAN............................................... 43

FIGURA 8 - GRÁFICO REFERENTE AOS FATORES DE MOVIMENTO DENTRO DA REPRESENTAÇÃO GRÁFICA DO SISTEMA EFFORT/SHAPE...... 44

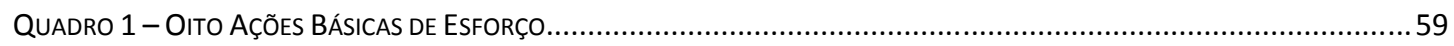

FIGURA 9 - ATRIZ-BAILARINA SISSI BETINA VENNTURIN REALIZANDO A SEQUÊNCIA DE MOVIMENTOS DA ABE TORCER..............62

FIGURA 10 - ATRIZ-BAILARINA SISSI BETINA VENNTURIN REALIZANDO A SEQUÊNCIA DE MOVIMENTOS DA ABE FLUTUAR...........62

FIGURA 11 - ATRIZ-BAILARINA KALISY CABEDA REALIZANDO A SEQUÊNCIA DE MOVIMENTOS DA ABE TORCER. .......................62

FIGURA 12 - ATRIZ-BAILARINA KALISY CABEDA REALIZANDO A SEQUÊNCIA DE MOVIMENTOS DA ABE PRESSIONAR. ..................63

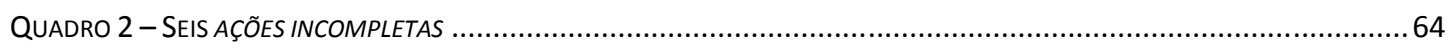

FIGURA 13 - AtRIZ-BAILARINA SISSI BETINA VENNTURIN REALIZANDO A SEQUÊNCIA DE MOVIMENTOS DA AI ONÍRICO. ..............65

FIgURA 14 - AtriZ-BAILARINA SISSI BETINA VENNTURIN REALIZANDO A SEQUÊNCIA DE MOVIMENTOS DA AI MóVEL................65

FIgURA 15 - AtrIZ-BaILARINA Kalisy CABEdA REALIZANDO A SEQUÊNCIA DE MOVIMENTOS DA AI PERTO..............................65

FIGURA 16 - AtRIZ-BAILARINA Kalisy CABEDA REALIZANDO A SEQUÊNCIA DE MOVIMENTOS DA AI ESTÁVEL. .........................66

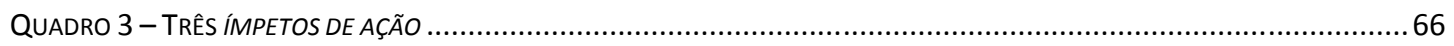

FIGURA 17 - ATRIZ-BAILARINA SISSI BETINA VENNTURIN REALIZANDO A SEQUÊNCIA DE MOVIMENTOS DO IA PAIXÃO. .............67

FIGURA 18 - ATRIZ-BAILARINA SISSI BETINA VENNTURIN REALIZANDO A SEQUÊNCIA DE MOVIMENTOS DO IA VISÃO. ................68

FIGURA 19 - ATRIZ-BAILARINA KALISY CABEDA REALIZANDO A SEQUÊNCIA DE MOVIMENTOS DO IA ENCANTO. .......................68

FIGURA 20 - AtRIZ-BAILARINA KalISY CABEDA REALIZANDO A SEQUÊNCIA DE MOVIMENTOS DO IA VISÃO............................68

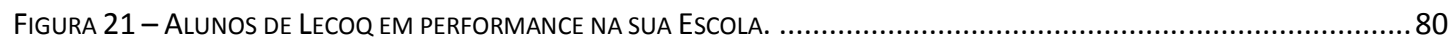

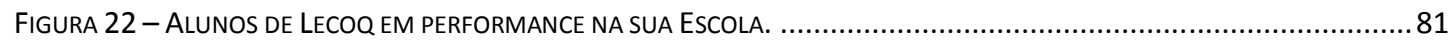

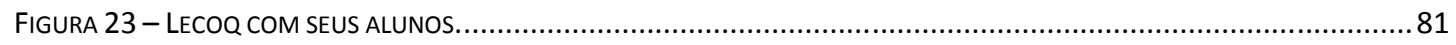

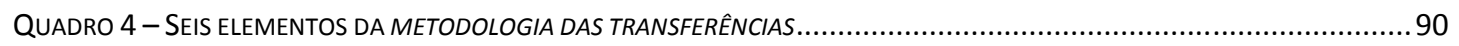

FIGURA 24 - ATRIZ-BAILARINA SISSI BETINA VENTURIN REALIZANDO A SEQUÊNCIA DE MOVIMENTOS DO ELEMENTO FOGO.........92

FIGURA 25 - ATRIZ-BAILARINA SISSI BETINA VENTURIN REALIZANDO A SEQUÊNCIA DE MOVIMENTOS DO ELEMENTO ÁGUA.........92

FIGURA 26 - ATRIZ-BAILARINA KALISY CABEDA REALIZANDO A SEQUÊNCIA DE MOVIMENTOS DO ELEMENTO METAL...................93

FIGURA 27 - ATRIZ-BAILARINA KALISY CABEDA REALIZANDO A SEQUÊNCIA DE MOVIMENTOS DO ELEMENTO AR........................93

FIGURA 28 - AtRIZES-BAILARINAS: SISSI BETINA VentURIN E KaLISY CABEDA....................................................... 120

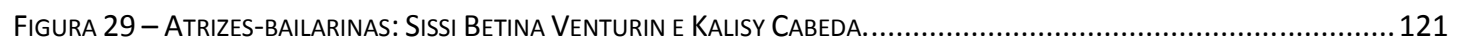

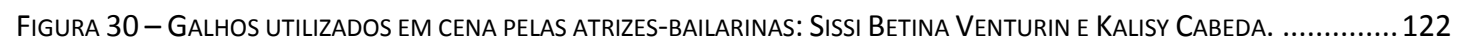

FIGURA 31 - OBJETOS UTILIZADOS EM CENA: MACHADO E TRONCO. .................................................................... 122

FIGURA 32 - INSTRUMENTOS DE PERCUSSÃO E SOPRO UTILIZADOS EM CENA, DA DIREITA PARA A ESQUERDA: HARMÔNICO, CHOCALHO DE PALHA, APITOS DE MADEIRA, CONDUITE DE METAL, BAQUETAS, TORNOZELEIRAS-CHOCALHO DE SEMENTES, MARACÁS

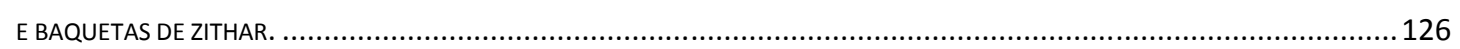

FIGURA 33 - MAPA DE LUZ DO EXERCÍCIO CÊNICO: O SENTIDO SE SENTE COM O CORPO. ................................................. 128

FIGURA 34 - CARTAZ DE DIVULGAÇÃo DO EXERCÍCIO CÊNICO: O SENTIDO SE SENTE COM O CORPO. ....................................130

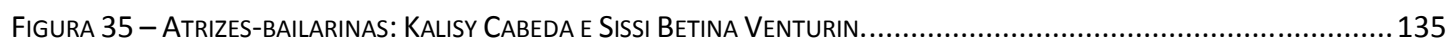

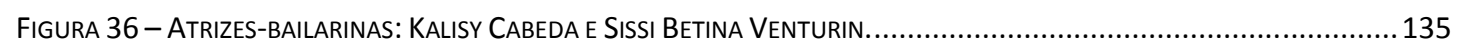

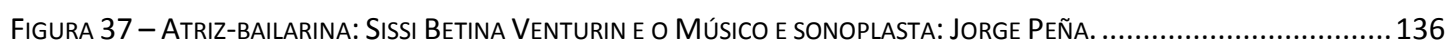

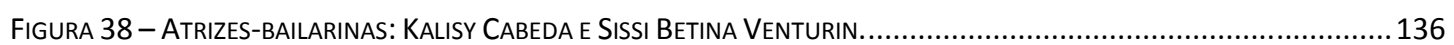




\section{SUMÁRIO}

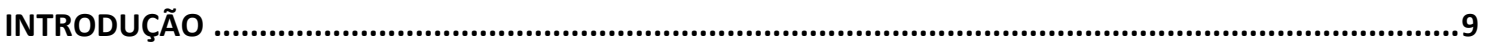

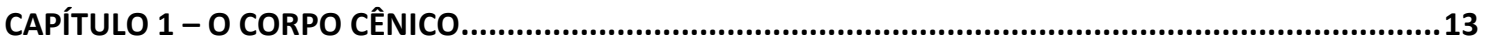

1.10 corpo cênico como reinvenção de linguagem ..........................................................................14

1.2 Corpo cênico contemporâneo: um possível operador de gestos virtuais......................................20

1.3 Consciência do corpo ou corpo de consciência ..............................................................................27

\section{CAPÍTULO 2 - LABORATÓRIO DE CRIAÇÃO: DESENVOLVENDO O CORPO CÊNICO A PARTIR DE PRINCÍPIOS DO SISTEMA DE MOVIMENTO DE RUDOLF VON LABAN................................................34}

2.1 Rudolf von Laban: um breve contexto sobre a experiência ..........................................................36

2.2 Os procedimentos metodológicos de nossa experiência: coreologia, corêutica e eukinética..........40

2.3 Laboratório de Criação: estruturação de nossa experiência, objetivos e rotina ...............................45

2.4 Laboratório de Criação: nossa experiência sobre os quatro fatores de movimento.........................48

2.4.1 Laboratório de Criação: investigação sobre o fator peso .............................................................51

2.4.2 Laboratório de Criação: investigação sobre o fator tempo ..........................................................53

2.4.3 Laboratório de Criação: investigação sobre o fator fluência ........................................................54

2.4.4 Laboratório de Criação: percepções de nossa experiência sobre os fatores de movimento .........56

2.5 Laboratório de Criação: experiência sobre as oito ações básicas de esforço ...................................57

2.5.2 Laboratório de Criação: investigação sobre as seis ações incompletas ......................................63

2.5.3 Laboratório de Criação: investigação sobre os três ímpetos de ação ...........................................66

2.6 Laboratório de Criação: percepções finais de nossa experiência sobre os princípios de movimentos

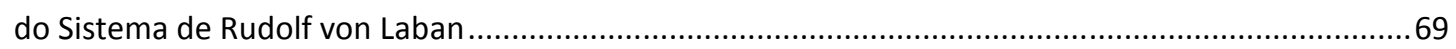

CAPÍTULO 3 - LABORATÓRIO DE CRIAÇÃO: DESENVOLVENDO O CORPO CÊNICO A PARTIR DE

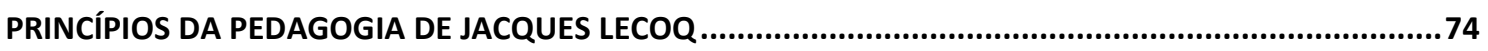

3.1 Jacques Lecoq: um teatro do corpo e do movimento...................................................................76

3.2 Lecoq e a viagem pessoal: uma breve estruturação da pedagogia de Lecoq segundo sua Escola.. 81

3.3 Estruturando a nossa própria viagem: a metodologia das transferências e o estudo das dinâmicas

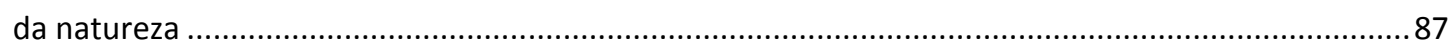

3.4 Laboratório de Criação: nossa viagem pessoal sobre a metodologia das transferências................90

3.5 Laboratório de Criação: percepções sobre a nossa viagem pessoal dentro da metodologia das transferências.................................................................................................................................93

3.6 Laboratório de Criação, percepções finais: a experiência em Laban e a viagem pessoal em Lecoq97

CAPÍTULO 4 - OS TRAJETOS DO PERCURSO CRIATIVO: O SENTIDO SE SENTE COM O CORPO..............101

4.1 Primeiro trajeto: combinação das sequências individuais de movimentos em células coreográficas .. 104

4.2 Segundo trajeto: organização das células coreográficas para um roteiro cênico... 109

4.3 Terceiro trajeto: relação entre as diferentes camadas: o roteiro cênico, a poesia textual, a textura sonora e a iluminação 120

4.4 Quarto trajeto: apresentação do exercício cênico de composição O Sentido de Sente com o Corpo para o público

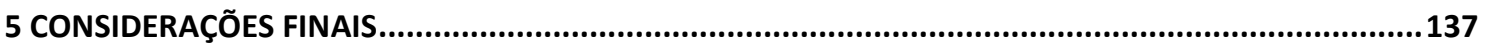

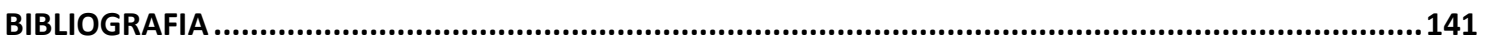




\title{
INTRODUÇÃO
}

Esta dissertação foi elaborada e escrita a partir de nossa pesquisa sobre o corpo cênico e seus aspectos técnico-artísticos dentro de um processo de criação. Nosso percurso investigativo/criativo foi percorrido a partir de nossa experiência na criação de um exercício cênico de composição, que teve como título O Sentido se Sente com o Corpo ${ }^{1}$.

Através de nossa práxis, que teve como objetivo estudar alguns mecanismos de construção de linguagem com base no corpo cênico e sua fisicalidade poética, foi possível experienciar e realizar certas reflexões e constatações relevantes, que serão expostas ao longo desta dissertação. Nossa pesquisa se configura enquanto pesquisa qualitativa, pois foi através de nossa prática e experiência que nosso conhecimento pôde ser vivenciado e adquirido. Esse tipo de pesquisa pretende abordar os fatos a partir da experiência dos indivíduos envolvidos e compreender como esses indivíduos constroem o mundo a sua volta em termos que façam sentido e ampliem a gama de informações a respeito do assunto estudado/analisado. Segundo Deslauriers (1991),

\begin{abstract}
Na pesquisa qualitativa, o cientista é ao mesmo tempo o sujeito e o objeto de suas pesquisas. $O$ desenvolvimento da pesquisa é imprevisível. O conhecimento do pesquisador é parcial e limitado. $O$ objetivo da amostra é de produzir informações aprofundadas e ilustrativas: seja ela pequena ou grande, o que importa é que ela seja capaz de produzir novas informações. (DESLAURIERS, 1991, apud GERHARDT e SILVEIRA, 2009, p. 32)
\end{abstract}

Nossa pesquisa se adequou a essa visão, pois foi realizada de forma experimental. Os métodos e os resultados foram sendo testados e descobertos ao longo de nosso caminho investigativo/criativo, que teve como objeto de estudo os corpos cênicos das pesquisadoras envolvidas. Além do corpo cênico, nossa pesquisa qualitativa se baseou em nossa percepção e sensibilidade, tão caras ao processo de formulação de conhecimento como ao processo criativo. Segundo Tartuce (2006), a produção de conhecimento se realiza através da assimilação que o individuo faz de suas vivências e experiências:

\footnotetext{
${ }^{1}$ Frase retirada do poema Zen-Riders, de Josely Vianna Baptista no livro: BAPTISTA, Josely Vianna: Corpografia: autópsia poética das passagens Josely Vianna Baptista, Francisco Faria. São Paulo: lluminuras, 1992.
} 
Ao viver, o ser humano tem experiências progressivas, da dor e do prazer, da fome e saciedade, do quente e do frio, entre muitas outras. É o conhecimento que se dá pela vivência circunstancial e estrutural das propriedades necessárias à adaptação, interpretação e assimilação do meio interior e exterior do ser. Dessa maneira, ocorrem, então, as relações entre sensação, percepção e conhecimento, sendo que a percepção tem uma função mediadora entre o mundo caótico dos sentidos e o mundo mais ou menos organizado da atividade cognitiva. É importante frisar que 0 conhecimento, como também o ato de conhecer, existe como forma de solução de problemas próprios e comuns à vida. (...) $O$ conhecimento é um processo dinâmico e inacabado, serve como referencial para a pesquisa tanto qualitativa como quantitativa das relações sociais, como forma de busca de conhecimentos próprios das ciências exatas e experimentais. (TARTUCE, 2006, apud GERHARDT e SILVEIRA, 2009, p. 17)

A produção de conhecimento também se mostra como processo perceptivo e sensível, bem como o percurso criativo que é conduzido pela sensibilidade na configuração e elaboração de formas. É ao elaborar e ordenar que o homem se reconhece e se distingue enquanto ser criativo, pois, ao perceber seu potencial criador, cria formas e transforma o mundo ao redor. De acordo com a artista e pesquisadora Fayga Ostrower (2013) a percepção de si mesmo é um ponto fundamental no ato criativo.

A percepção de si mesmo dentro do agir é um aspecto relevante que distingue a criatividade humana. Movido por necessidades concretas sempre novas, o potencial criador do homem surge na história como um fator de realização e constante transformação. (OSTROWER 2013, p. 10)

Assim, em nossa caminhada na construção de conhecimento através do ato criativo, a sensibilidade e a percepção se tornaram guias importantes. Nesse percurso, reconhecemos elementos relevantes que nortearam nossas investigações e reflexões, como: noções históricas e filosóficas a respeito do corpo cênico; a elaboração de uma metodologia de trabalho que compreendesse aspectos técnico-artísticos do corpo e a criação de um exercício cênico de composição. Todos esses aspectos foram investigados em nosso percurso de pesquisa com o intuito de elaborar uma linguagem artística que encontra no corpo cênico seu material poético. Esse trajeto investigativo/criativo pode ser observado e acompanhado ao longo dos quatro capítulos que compõem esta dissertação.

No primeiro capítulo, intitulado O Corpo Cênico, realizamos uma reflexão sobre o corpo cênico segundo algumas estéticas teatrais que, ao longo do século XX, fizeram do ator em cena seu principal material de criação e 
comunicação. Nessa abordagem, percebemos o corpo como fundamental matéria de criação que se reflete até os dias atuais em diferentes encenações cênicas, nas quais as fronteiras entre o teatro e a dança acabam sendo rompidas através de uma fisicalidade marcante que determina muitas estéticas contemporâneas. Encontramos nas reflexões sobre dança, corpo e movimento do filósofo português José Gil (1939-) um possível caminho para refletir sobre o corpo cênico contemporâneo, utilizando as noções de Gil sobre corpo virtual, de Susanne Langer (1895-1985), filósofa norte-americana especialista em filosofia da arte, sobre gestos virtuais, e de António Pinto Ribeiro sobre fisicalidade.

O segundo capítulo intitula-se Laboratório de criação: Desenvolvendo o Corpo Cênico a partir de Princípios do Sistema de Movimento de Rudolf Von Laban. Com o intuito de experienciar fisicamente aspectos técnico-artísticos relativos ao corpo cênico contemporâneo, elaboramos uma metodologia de trabalho baseada em uma rotina de exercícios oriundos do Sistema de movimento de Rudolf Von Laban $(1879$ - 1958) e da pedagogia de Jacques Lecoq (1921-1999). Nesse segundo capítulo abordamos aspectos históricos, metodológicos, técnicos e artísticos no que se refere aos quatro fatores de movimento (espaço, tempo, peso e fluência) ${ }^{2}$ presentes no Sistema Laban. Nesse percurso, realizamos nossas experiências dentro do Laboratório de Criação, no qual investigamos fisicamente os quatro fatores de movimento e refletimos sobre as constatações e resultados alcançados na busca pela consciência e percepção do corpo cênico como material sensível e criativo.

No terceiro capítulo, intitulado Laboratório de criação: Desenvolvendo o Corpo Cênico a partir de Princípios da Pedagogia de Jaques Lecoq, seguimos com nossas investigações sobre aspectos técnico-artísticos relativos ao corpo cênico contemporâneo. Dando continuidade à elaboração de nossa metodologia, abordamos aspectos históricos, metodológicos, técnicos e artísticos no que se refere à pedagogia de Jacques Lecoq e sua metodologia das transferências. ${ }^{3}$ Realizamos nossas experiências dentro do Laboratório de Criação, no qual

\footnotetext{
2 As noções e as referências sobre os fatores de movimento de Laban encontram-se expostas detalhadamente no capítulo dois desta dissertação. ${ }^{3}$ As noções e as referências sobre a metodologia das transferências de Lecoq encontram-se expostas
detalhadamente no capítulo três desta dissertação.
} 
investigamos fisicamente a metodologia das transferências e refletimos sobre os resultados alcançados na busca pela consciência e percepção do corpo cênico como material sensível, criativo e poético.

O quarto capítulo intitula-se Os Trajetos do Percurso Criativo: O Sentido se Sente com o Corpo. Com o intuito de levar para cena e apresentar em público os aspectos técnico-artísticos experienciados ao longo dos Laboratórios de Criação sobre Laban e Lecoq, realizamos a criação do exercício cênico de composição O Sentido se Sente com o Corpo. Nesse capítulo são expostos os trajetos percorridos na criação do exercício e sua elaboração cênica baseada na fisicalidade singular de cada atriz-bailarina. Também são apresentadas as considerações e os resultados observados neste processo, retomando algumas noções apresentadas no capítulo um, como os gestos virtuais, de Langer (1980), e o corpo virtual, de Gil (2004).

Nas Considerações Finais realizamos o levantamento de algumas conclusões relevantes que se fizerem presentes ao longo de nossa jornada investigativa/criativa, guiada pela sensibilidade e percepção na elaboração de um conhecimento fundamentado sobre as potencialidades poéticas presentes no corpo cênico. 


\section{CAPÍTULO 1 - O CORPO CÊNICO}

Neste primeiro capítulo, abordamos questões sobre o corpo cênico e sua relação com a criação artística e realizamos uma pequena reflexão sobre o corpo cênico dentro de algumas estéticas teatrais do século XX. Optamos por abordar o corpo cênico dentro dos parâmetros teatrais por ser esta a primeira aérea de formação da pesquisadora que aqui vos escreve, com a realização do curso de Teatro Bacharelado, Habilitação em Direção Teatral, na Universidade Federal do Rio Grande do Sul entre os anos de 2006 e 2010. ${ }^{4}$ A partir dessa experiência e de outras que se fizeram presentes ao longo de nosso percurso, entendemos o corpo como um importante propulsor na elaboração de linguagens cênicas em diferentes encenadores, os quais fundamentaram a construção de suas estéticas no material corpóreo criativo de seus atores. Percebemos o corpo como importante dispositivo de criação, que se reflete até os dias atuais em diferentes encenações cênicas que possuem o corpo como operador cênico e nas quais as fronteiras entre o teatro e a dança acabam sendo rompidas por meio de uma fisicalidade marcante que determina muitas estéticas contemporâneas.

Encontramos nas reflexões sobre dança, corpo e movimento do filósofo português José Gil (1939-), da filósofa norte-americana especialista em filosofia da arte Susanne Langer (1895-1985) e do crítico português António Pinto Ribeiro um possível caminho para refletir sobre o corpo cênico contemporâneo. Utilizamos algumas noções sobre o corpo (GIL, 2004), as noções de Langer (1980) sobre gestos virtuais e de Ribeiro (1994) sobre fisicalidade. Nessa breve análise, entendemos que o corpo cênico contemporâneo pode ser um corpo que constrói metáforas corporais por meio de gestos, os quais são mais que físicos, são gestos cinestésicos ${ }^{5}$ e imagéticos, gestos virtuais, segundo Langer (1980). Percebemos

\footnotetext{
${ }^{4}$ Esta experiência sobre a graduação em Teatro encontra-se descrita no capítulo três desta dissertação.

${ }^{5}$ Ao longo desta dissertação, utilizamos a palavra cinestésico por ela abranger o campo da cinestesia, que se refere à nossa capacidade de percepção e sensação dos movimentos, gestos e ações do corpo e suas propriedades, como peso, espaço, dinâmica, músculos e ossos. Esta capacidade cinestésica está muito presente nas habilidades técnico-artísticas de artistas do corpo cênico. Segundo o Dicionário Michaelis (1998), "a cinestesia refere-se ao sentido muscular, a um conjunto de sensações que nos permite a percepção dos movimentos".
} 
que, na busca por um corpo produtor de gestos virtuais, se faz necessária a consciência sobre o corpo, o que Gil (2004) chama de corpo de consciência.

Com a finalidade de elaborar uma consciência sobre o corpo, apontamos para a necessidade de uma prática física que aborde aspectos técnicoartísticos, imagéticos e sensoriais do corpo. Nessa direção, partimos de nossa experiência artística tanto nas áreas da dança quanto do teatro e encontramos nas práticas sobre o Sistema de Rudolf Von Laban (1879-1958) e da pedagogia de Jacques Lecoq (1921-1999) uma possibilidade de despertar nossa percepção para uma consciência sobre o corpo.

\subsection{O CORPO CÊNICO COMO REINVENÇÃO DE LINGUAGEM}

A história do teatro ocidental compreende um grande e extenso campo de investigação inserido em muitas correntes, movimentos e estéticas, nos quais é possível encontrar distintas abordagens e conceitos sobre aspectos como a dramaturgia, a encenação e o trabalho do ator. Sendo assim, pretendemos aqui refletir sobre o trabalho do ator, tendo em vista a utilização corporal como uma fonte de criação poética.

Neste sentido, abordamos o teatro do início do século XX, que instigou uma reinvenção da linguagem cênica e, por consequência, uma reteatralização ${ }^{6}$ do corpo do ator. No início do século $X X$, o teatro, em sua grande parte um teatro realista no qual o texto era o principal veículo de criação, começou a enfrentar uma crise do drama (SZONDI, 2001), uma crise do teatro realista/naturalista que estaria presente por todo o século. Como resposta a essa crise, outros textos começaram a ser escritos, como os simbolistas, que tinham por objetivo justamente questionar a arte como simples imitação da realidade. Muitos artistas foram adeptos deste movimento, entre eles o poeta e dramaturgo belga Maurice Maeterlinck (1862 -1949). Maeterlinck escreveu muitas peças para o teatro simbolista, as quais possuíam como principal característica a ausência de conflito e de ação; seus personagens não necessitavam de uma interpretação tradicional com fins didáticos ou de entretenimento, eram como sombras que realizavam

\footnotetext{
${ }^{6}$ Aqui utilizamos o termo reteatralização, pois o corpo do ator como linguagem cênica é utilizado desde o teatro na Idade Média, nos chamados Mistérios.
} 
gestos sem uma função lógica relacionada ao texto dramático. Além do simbolismo, outros movimentos surgiram como resposta a essa crise, como o expressionismo, o futurismo e o surrealismo. Todos propunham novas formas dramatúrgicas que divergiam do realismo vigente até então.

A partir das novas propostas dramatúrgicas que surgiram desses movimentos, foi necessário pensar como estes textos e estes personagens poderiam ser interpretados em cena, tendo em vista que o teatro produzido na época era em sua maioria realista, no qual eram representados personagens e situações tais quais como haviam na vida real. Como seria possível encenar esses textos? Como representar esses personagens? Ao pensarmos sobre encenação e sobre o trabalho de ator naquele período, é preciso lembrar-se de alguns encenadores e pesquisadores que ao longo do século $X X$ investigaram a construção de uma cena teatral, na qual o foco da criação não estava no texto e sim na visualidade e nos signos proposto pelo cenário, pela luz e pelo corpo do ator. Entre eles estão: Vsevolod Meyerhold (1874-1940), Jacques Copeau (1879-1949), Antonin Artaud (1896-1948), Edward Gordon Craig (1872-1966), entre outros. Todos eles buscavam uma reteatralização do teatro, cada qual através de suas pesquisas: Meyerhold pelo método da Biomecânica $^{7}$, Copeau pelo trabalho físico do ator dentro do théâtre du VieuxColombier, ${ }^{8}$ Artaud pela reinvenção da linguagem, como demonstra em seu livro O teatro e seu duplo (ARTAUD, 1999), e Craig pela teoria da supermarionete. Entre todos estes, encontramos o trabalho corporal do ator como um foco norteador de suas pesquisas, pois acreditavam que o corpo em cena poderia ser a chave na construção de suas linguagens e estéticas.

Meyerhold, por exemplo, foi um grande encenador russo que investigou uma encenação baseada nos moldes simbolistas e fundamentada na convenção e no artificialismo, em oposição ao realismo. Para desenvolver uma

\footnotetext{
${ }^{7}$ Biomecânica - Estudo da mecânica aplicada ao corpo humano. Meyerhold utiliza esta expressão para descrever um método de treinamento de ator baseada sobre a execução de tarefas. A técnica biomecânica se opõe ao método introspectivo, 'inspirado' nas emoções autênticas. O ator aborda seu papel do exterior, antes de pegá-lo intuitivamente. (PAVIS, 1999)

8 Jacques Copeau foi um influente diretor de teatro, produtor, ator e dramaturgo francês. Foi fundador do famoso Théâtre du Vieux-Colombier, em Paris, no qual desenvolveu sua pesquisa sobre o ator e seus movimentos, que se encontra mais detalhadamente no capítulo três desta dissertação.
} 
encenação baseada na convenção e no grotesco, buscou um ator que rompesse com os moldes realistas e que pudesse ser operador de uma encenação repleta de códigos e jogos. Em sua busca por um ator que se utilizasse da máscara como veículo de comunicação e diálogo com o público, elaborou um sistema de trabalho para desenvolver as habilidades técnicas desse ator (Biomecânica), que necessitava de um corpo preparado e treinado dentro das leis da convenção e do artificialismo da arte. Meyerhold, ao idealizar uma cena polifônica, em que cada elemento era uma camada do discurso cênico, deslocou o ator, que passou a ser visto como um elemento detentor de um discurso que deve ser claramente exposto ao espectador. O corpo deveria ser uma máscara que o ator vestiria, estabelecendo assim a convenção com o público. Os atores trabalhavam para ter domínio do tempo e do espaço e assim manipular e mostrar com clareza os códigos da encenação para o espectador.

(...) O ator era um dançarino, um músico, um escultor da cena, e a personagem-máscara que representava reunia, polifonicamente, temas e arquetípicos eternos e as encarnações reais de seu tempo. Ao formular o princípio da polifonia teatral, no qual os elementos que compunham a cena perdiam a sua função ilustrativa e ganhavam autonomia, podendo, inclusive, divergir, o encenador sugeria para o ator o mesmo caminho isto é, que ele próprio se tornasse um instrumento polifônico. (THAís, 2009, p. 105)

Seguem duas fotos sobre algumas práticas da Biomecânica de Meyerhold.

Figura 1

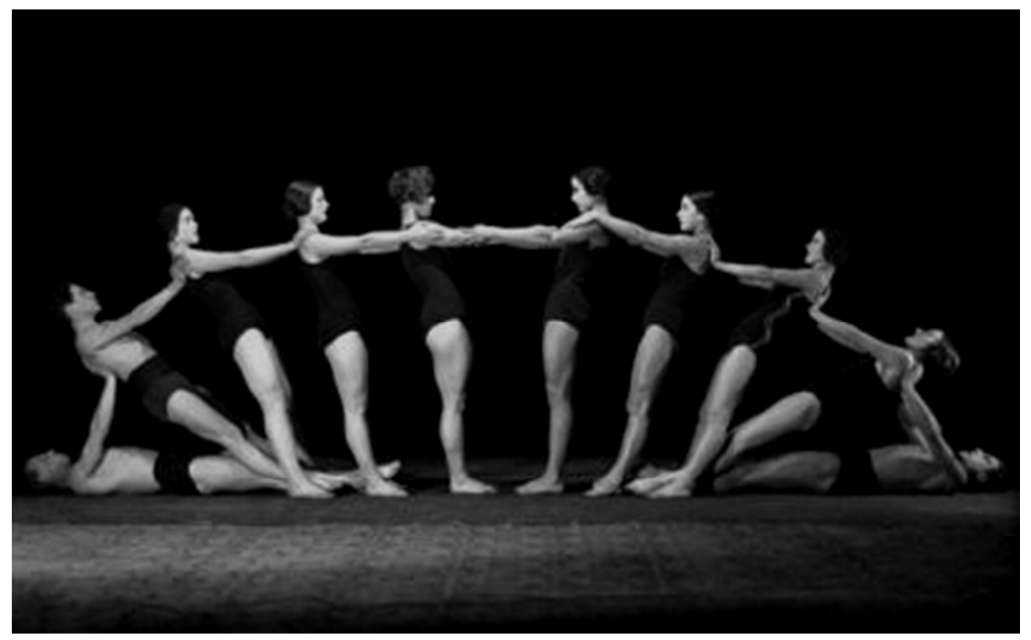

Fonte: http://teatrodemaquinaria.wordpress.com/category/meyerhold/ Acesso em 25 de maio de 2014. 
Figura 2

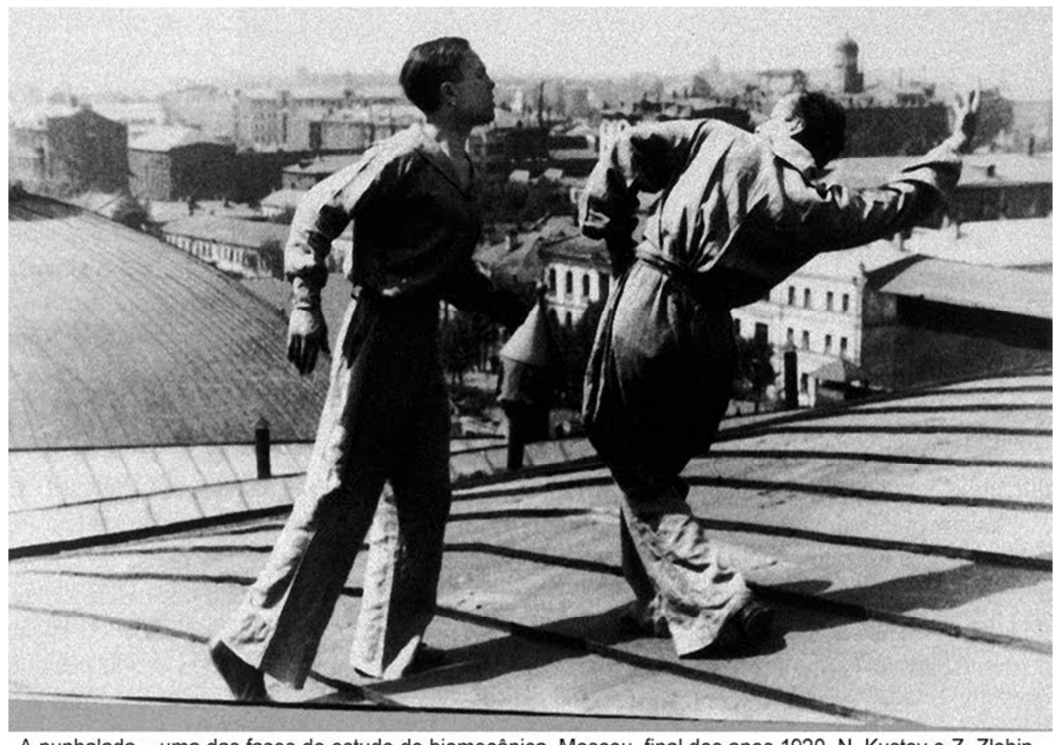

A punhalada - uma das fases do estudo de biomecânica. Moscou, final dos anos 1920. N. Kustov e Z. Zlobin.

Fonte: http://meyerhold70anos.blogspot.com.br/ Acessado em 25 de maio de 2014.

No caso de Craig, ele propôs uma ruptura com a cena teatral naturalista. As suas experimentações foram desde o cenário e da iluminação até o trabalho físico do ator. Craig acreditava que o fenômeno teatral deveria ser uma obra perfeita e passível de reprodução. Quanto à questão técnica (cenário, luz e figurino), essa reprodução era possível, porém o corpo do ator, segundo ele, não era capaz de reproduzir exatamente o que era realizado em cena devido à emoção, à imprecisão corporal e à improvisação. Para ele, o ator deveria ter consciência espacial e corporal através da criação de gestos simbólicos. Sendo assim, propôs que os atores deveriam ser substituídos por marionetes, que poderiam realizar com precisão e perfeita capacidade de reprodução todos os movimentos feitos em cena.

A teoria da supermarionete questiona a presença do ator, do corpo como matéria artística, a referência da marionete, do boneco, não é do títere, mas de figuras feitas "á imagem de Deus", imagens de ídolos, que não tinham necessidade de fios e manipulação para expressarem algo. Sendo um corpo não humano está esvaziado de vaidades e emoções, sendo assim, livre para poder estar dentro da arte da encenação. (CRAIG, 1963, p. 55)

As inovações de Craig foram fruto da sua grande fascinação pelo movimento de composição dos elementos e do corpo do ator em cena. A partir da movimentação e do domínio corporal, o ator teria uma liberdade na construção dos signos dos gestos e ações, libertando-se assim da lógica 
racional dos movimentos. Através do cenário, da iluminação e da supermarionete, Craig buscava uma cena mais visual, na qual o espectador era solicitado a imaginar através das imagens e elementos visuais. É preciso frisar que Craig não desejava eliminar o ator do teatro, mas sim encontrar, na figura da marionete, um ator em perfeita harmonia com a cena, um ator que estivesse o tempo todo a serviço da obra.

A partir desses dois exemplos, podemos perceber o quanto o corpo cênico foi investigado como forma de linguagem e de estética e como há tempos vem sendo o norteador de pesquisas artísticas que acreditam na reinvenção da linguagem através do corpo. Encenadores como Meyrhold e Craig encontraram uma estética própria que possuía uma relação direta com o texto dramático, a principal fonte de poesia daquele teatro, ou seja, o trabalho corporal desenvolvido por eles estava relacionado diretamente com a narrativa, pois os elementos da cena, cenário, luz, figurino e atuação, eram criados a partir do texto teatral e pretendiam contar uma história para os espectadores.

Nosso teatro contemporâneo, porém, rompeu a ligação entre texto e cena e entre narrativa e personagem. Os elementos da cena são independentes entre si, o texto dramático muitas vezes não é utilizado, os limites entre ator e espectador são muitas vezes borrados e dança, teatro e vídeo são linguagens que se mesclam, como nos diz Lehmann (2007) em seu livro sobre o teatro pós-dramático:

\begin{abstract}
Com isso tornou-se concebível não só a dissolução da tradicional fusão de texto e palco, como também a perspectiva de uma nova relação entre texto e palco. À medida que o texto teatral passou a ter o valor de uma grandeza poética independente e que a "poesia" do palco, liberada do texto, passou a ser pensada como uma poesia atmosférica própria, do espaço e da luz, inseriu-se no campo do possível um dispositivo teatral que instalou no lugar da unidade automática a dissociação e em seguida a combinação livre (libertada) não só o texto e palco, mas todos os signos teatrais. (LEHMANN, 2007, p. 97)
\end{abstract}

No contexto deste teatro contemporâneo que pretende, muitas vezes, refletir sobre um homem cada vez mais fragmentado, a linguagem produzida é visual e simbólica e os recursos técnicos e expressivos ganham uma independência e podem ser combinados de maneiras distintas. O resultado é uma cena imagética e cinestésica, em que as metáforas ganham vida e a cena 
se desliga de uma narrativa textual com razão lógica. Porém, da mesma forma que o teatro simbolista precisava de um ator que fosse veículo de símbolos, como a supermarionete de Craig, as encenações contemporâneas necessitam de um ator que seja polissêmico, que possa ser um veículo de transmissão dos múltiplos símbolos e metáforas presentes em cena. Na medida em que o teatro se desligou do texto dramático, todos os elementos de cena adquiriram novas possibilidade de criação, e entre eles o ator e seu corpo. Assim, o corpo passou a ser não um corpo passivo e ligado as sentido semântico do texto, mas sim um agente provocador de signos e metáforas:

Foi necessária a emancipação do teatro como uma dimensão própria da arte para se compreender que o corpo, sem prolongar uma existência como significante, pode ser agente provocador de uma experiência livre de sentido, que não consiste na atualização de um real e de um significado, mas é experiência em potencial. (...) teatro do corpo é teatro do potencial. (LEHMANN, 2007, p. 336)

Segundo Lehmann (2007), o teatro do corpo é um teatro do potencial, em que o corpo tem potência para criar e gerar experiências, sensações, metáforas, poesias. O corpo como potência se vale de uma linguagem não verbal, uma linguagem física, uma linguagem que se articula a partir da combinação dos gestos em cena, gestos com potencial artístico e poético. É por meio das tensões físicas que o gesto pode gerar metáforas e poesia, assim como na dança. Como o crítico português Antônio Pinto Ribeiro (1994) nos fala em suas reflexões, neste teatro do corpo, assim como na dança, é a fisicalidade que substitui a narrativa:

E se no teatro o corpo do actor é tido como complementar nesta narratividade dramatúrgica, já nos espetáculos de dança a dramaturgia é realizada a partir dos movimentos e da gestualidade dos bailarinos, que com o seu corpo <dizem coisas>. Não se trata aqui de uma narratividade, mas de uma fisicalidade. (RIBEIRO, 1994, p. 18)

Nesse sentido, o ator do teatro do corpo, um teatro que se encontra muito nas encenações contemporâneas, se comunica não por meio do texto, mas através dessa fisicalidade que se estabelece a partir de gestos com potência poética. Qual é o corpo cênico necessário a esse teatro? Como perceber um corpo cênico que possa ser um elemento independente dos outros elementos da cena? Que possa criar uma fisicalidade repleta de gestos poéticos? Partindo dessas reflexões, percebemos que o corpo cênico 
contemporâneo exige do ator uma consciência, uma habilidade técnica e artística, uma fisicalidade potente que dialoga diretamente com a dança, é um corpo que compete não só ao ator, mas também ao bailarino, e atualmente essas funções estão muito próximas. Muitas vezes o ator é bailarino e viceversa, ou seja, essas duas formas de linguagem artística se misturam e se complementam no fazer cênico atual.

\begin{abstract}
A fisicalidade como fenômeno, ora alternativo ora convivente com a narratividade, impôs-se sobre as fronteiras dos gêneros. Onde antes se dizia que acabava o teatro e começava a dança, ou vice-versa - e havia ainda que contar com a fronteira intransponível da música-, veio o corpo num processo de alargamento horizontal confundir ao gêneros, ao que se respondeu com soluções como o Teatro-Dança ou o Teatro-físico. (RIBEIRO, 1994, p. 13)
\end{abstract}

A partir desse rompimento de fronteiras entre a dança e o teatro, o corpo se consagra como ponto de encontro de uma fisicalidade na qual as habilidades corporais dos bailarinos podem contribuir para o ator e as habilidades expressivas do ator, para o bailarino. Desta forma, uma fisicalidade poética pode ser visualizada nas atuais encenações. Nesse sentido, encontramos nas noções sobre o corpo, a dança e o movimento elaboradas pela filósofa norte-americana Suzanne Langer (1980) e pelo o filósofo português José Gil (2004) uma ponte que pode nortear este trânsito entre teatro e dança e ser um caminho para refletir sobre o trabalho desenvolvido pelo corpo cênico contemporâneo.

\title{
1.2 CORPO CÊNICO CONTEMPORÂNEO: UM POSSÍVEL OPERADOR DE GESTOS VIRTUAIS
}

José Gil, em seu livro Movimento Total, realiza uma reflexão filosófica sobre o corpo e a dança e aborda o trabalho de alguns importantes e brilhantes bailarinos e coreógrafos do século XX, como Merce Cunningham (1919-2009), Steve Paxton (1939-), Yvonne Rainer (1934-) e Pina Bausch (1940-2009). A partir das obras desses artistas, ele elabora uma interessante reflexão sobre o corpo e o movimento. Sobre cada um dos coreógrafos, Gil realiza uma elaboração racional para entender suas criações cênicas e, por consequência, o corpo que dança, pois, em cada caso, o corpo como linguagem coreográfica é revelado de forma distinta. 
Aqui acreditamos ser relevante destacar que os bailarinos e coreógrafos abordados por Gil (2004) são importantes e fundamentais artistas que repensaram e criaram o corpo cênico do bailarino a partir de suas estéticas e idealizações artísticas, assim como no teatro do século $X X$ os encenadores criaram e repensaram a cena a partir do corpo cênico do ator. Na dança, foram também inúmeros os coreógrafos e bailarinos que investigaram o corpo e seu potencial criativo na elaboração da estética. Por não possuírem o texto dramático como um elemento determinante, entre outros fatores, exploraram muito mais a fundo o corpo em seus aspectos perceptivos e sensíveis, alcançando resultados efetivos e decisivos na construção de uma fisicalidade baseada em gestos poéticos como operadores de suas criações artísticas e estéticas, que deram origem a inúmeros corpos poéticos, como nos diz a historiadora Annie Suquet (2008):

É esse território da mobilidade, consciente e inconsciente, do corpo humano que se abre para as explorações dos bailarinos no limiar do século $X X$. O sensível e o imaginário nele dialogam com infinito refinamento, suscitando interpretações, ficções perceptivas que dão origens a outros tantos corpos poéticos. (SUQUET, 2008: 516)

Como exemplo de bailarino e coreógrafo que desenvolveu uma estética baseada em uma fisicalidade poética, Gil (2004) nos fala de Cunnigham. Ele aponta que uma das características em suas coreografias é a criação de uma nova linguagem a partir do "movimento puro", um movimento que não teria referentes exteriores a ele. Para isso, Cunnigham esvazia o espaço exterior (cena) e o espaço interior (corpo) através da modificação do eixo de equilíbrio do corpo (coluna vertebral). O corpo encontra novas formas de equilíbrio e o bailarino tem que se concentrar no movimento, nas articulações e na energia do corpo para construir uma "gramática".

Imitando assim a maneira pela qual a natureza faz espaço e nele coloca um monte de coisas, pesadas e leves, pequenas e grandes, "todas sem relação umas com as outras, mas cada uma afetando todas as outras", escreve Cunningham. No interior: ele despoja a experiência do bailarino de seus elementos representativos ou emocionais como motores do movimento (balé e dança moderna). Como ele consegue isso? Obrigando a atenção do bailarino a se concentrar no movimento puro, ou seja, na "gramática". Ou seja: a consciência do corpo (awarenesss) se fixa na energia, nas articulações, nos movimentos, e não mais, de forma alguma, nas emoções ou nas imagens de uma narrativa (situação em que a 
consciência comanda a consciência do corpo; em Cunningham, a consciência do corpo comanda a consciência). (GIL, 1999, p. 6)

Segundo Gil, por meio do movimento puro em Cunningham, o bailarino constrói uma "gramática" usando a consciência sobre o corpo, assim ele realiza combinações de movimento para a elaboração de uma nova linguagem que será utilizada na criação coreográfica, que possui uma lógica própria que vai revelando seu sentido em cena.

Despojando a experiência do corpo das imagens e dos afetos, criando um vazio, a gramática sobressai, mas perdeu-se o que motiva e desencadeia o movimento. Para que a gramática possa "se tornar o sentido", como gosta de dizer Cunningham ("the grammar is the meaning"), ou para que ela possa se tornar um elemento constitutivo do movimento, é preciso que a própria "gramática dançada" se "preencha" de sentido, enfim, que este movimento seja dançado, possua sua lógica própria, seus elementos desencadeadores, sua orientação. (GIL, 1999, p. 7)

Seguem duas fotografias sobre o trabalho de Cunningham, uma com ele em cena e outra mostrando uma cena de sua companhia de dança.

Figura 3 - Merce Cunningham em performance, 1958.

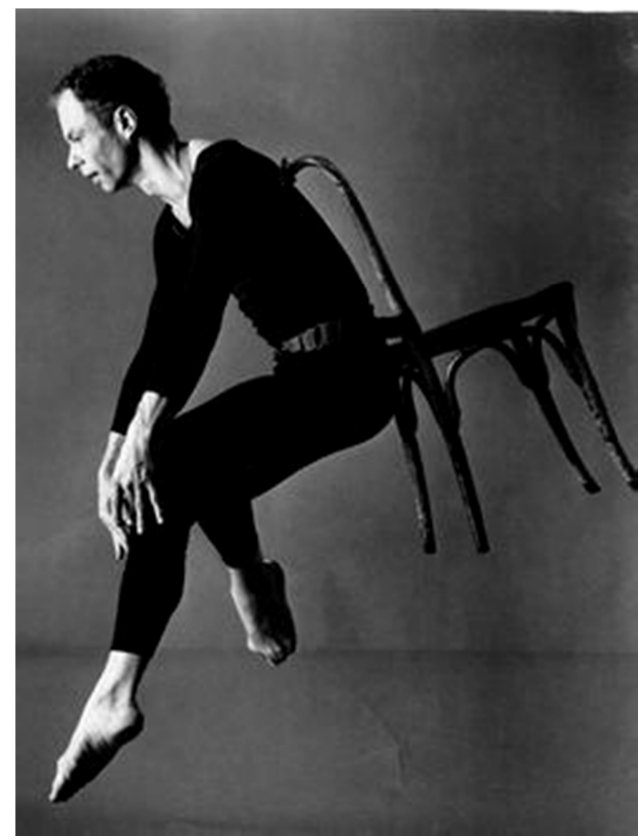

Fonte: http://www.wnyc.org/story/178388-merce-cunningham-dance-company/ Acessado em 25 de maio de 2014. 
Figura 4 - Merce Cunningham Dance Company, 2009.

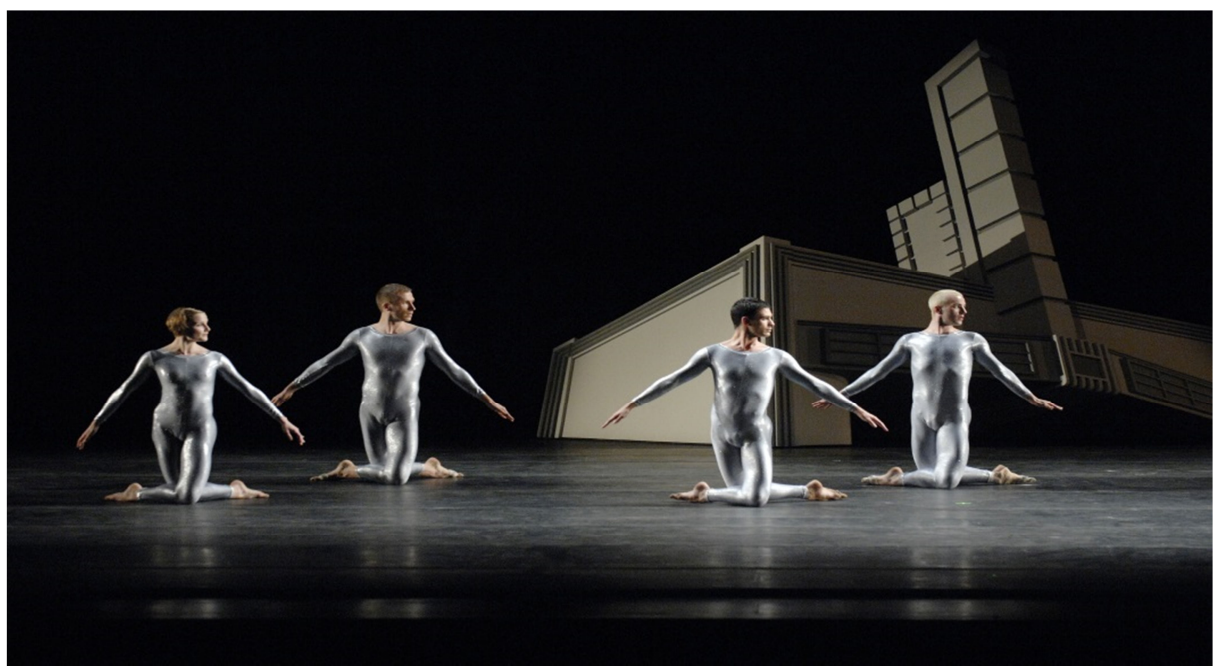

Fonte:http://newsroom.unl.edu/releases/2009/02/23/Merce+Cunningham+Dance+Co.+at+Lied+Center+Ma rch+7. Acesso em 25 de maio de 2014.

Ao falar em elementos como "movimento puro" e "gramática", Gil nos traz a ideia de que, para construir uma linguagem coreográfica, no caso, a linguagem de Cunningham, é necessário construir um corpo específico que corresponda a uma estética desejada. Nessa direção, ele nos leva a pensar sobre o corpo em cena como elaboração artística, pois o bailarino necessita se despojar da sua postura natural para criar um corpo cênico que é um corpo construído para estar em cena, um corpo artificial:

Deixando de adotar uma postura natural, o corpo dá-se um artifício, faz-se artificial: pode doravante tornar-se imagem, quer dizer matéria de criação de formas. A sua instabilidade em nada prenuncia aquilo em que vai tornar-se, não predeterminando nenhuma outra postura. (...) Procurando desestabilizar a atitude natural, o bailarino quer criar as condições que lhe permitirão tratar o corpo como um material artístico. (Gil, 2004, p. 22)

Com o objetivo de tratar o corpo como material artístico, Gil traz o exemplo do equilíbrio que o bailarino deve ter em algumas posturas corporais difíceis de alcançar e que exigem, além de um conjunto de forças físicas e mecânicas, uma concentração, uma consciência do movimento que implica uma consciência sobre o corpo.

Agora, já não é simplesmente o fato de se estar consciente que mantém o corpo em equilíbrio, mas a consciência do movimento que o percorre. O equilíbrio é dinâmico, enquanto equilíbrio de forças e de massas em movimento; ora, quando a consciência do movimento se torna movimento da consciência (porque é assim que a 
"concentração" da consciência sobre o corpo se define), é o conjunto do movimento que cria o equilíbrio. (Gil, 2004, p. 23)

Para alcançar essa consciência do movimento, é preciso acessar um campo de forças que vão além das forças mecânicas do corpo; são forças de dança. Segundo Susanne Langer (1980), forças de dança se estabelecem para além do "campo de forças" da física, são forças da experiência subjetiva do sujeito, que é realizada através da consciência sobre si mesmo. Para Langer, é através da consciência que o bailarino pode elaborar o gesto, que é o material primário da dança. É a partir desse gesto que a ilusão pode ser criada e organizada e se tornar um gesto artístico, um gesto poético, um gesto virtual.

Todo ser que faz gestos naturais é um centro de força vital, e seus movimentos expressivos são vistos por outros como sinais de sua volição. Mas gestos virtuais não são sinais, são símbolos de volição. O caráter espontaneamente gestual dos movimentos da dança é ilusório, e a força vital que expressam é ilusória; os "poderes" (isto é, centros de força vital) na dança são seres criados. (LANGER, 1980, p. 184).

Na visão defendida por Langer, o gesto é a abstração que a dança cria e, por ser abstrato, ele é ilusório e estabelece uma relação de força entre os bailarinos, um jogo de poder no qual essas forças podem ser sentidas pelos bailarinos e pelos espectadores. Este campo de forças de dança cria o que ela chama de esfera virtual de poder.

(...) concebe a dança como sendo nem arte plástica, nem música, nem uma apresentação de uma estória, mas um jogo de Poderes tornados visíveis.(...) a concepção da dança como uma arte completa e autônoma, a criação e a organização de uma esfera de Poderes virtuais. (LANGER, 1980, p. 196)

Então a dança cria um jogo de poderes a partir do gesto virtual que surge do campo de forças vitais, possível por meio da consciência e experiência subjetiva do bailarino sobre o seu corpo. Assim como Langer (1980) nos fala do gesto virtual na dança, ela nos traz a noção de ação virtual no teatro. Segundo ela, a matéria-prima do teatro é o ato, é a ação, e ela é virtual, pois acontece no presente, mas remete a um futuro no qual há uma possibilidade, uma potência. Nesse sentido, se pensarmos no teatro do corpo, o qual encontra na fisicalidade a base da criação, a ação virtual é movimento e, sendo movimento, é gesto. Um gesto em potência, por sua vez, é um gesto virtual. Assim, a ação virtual, que pode se tornar um gesto virtual, acontece no corpo a partir de forças físicas, mas 
também subjetivas, já que ação e gesto nascem de uma vontade interior do atorbailarino. Desta forma, podemos perceber que, além do corpo físico, de ossos, músculos e tensões, existe algo que está no interior disso tudo, algo que se relaciona com o lado subjetivo das sensações e que pode ser acessado a partir da consciência sobre o corpo físico, de suas tensões, de sua força, de seus equilíbrios e desequilíbrios. Pode-se chegar a perceber o corpo de forma mais sensorial, cinestésica e imagética. A partir da concretização dos movimentos e gestos macroscópicos do corpo físico, pode-se chegar a perceber os movimentos microscópicos e sutis do corpo:

\begin{abstract}
A arte do bailarino consiste assim em construir um máximo de instabilidade, em desarticular as articulações, em segmentar os movimentos, em separar os membros e os órgãos a fim de poder reconstruir um sistema de um equilíbrio infinitamente delicado - uma espécie de caixa de ressonância ou amplificador dos movimentos microscópicos do corpo: esses nomeadamente cinestésicos, sobre os quais a consciência não pode ter controle a não ser concentrando-se neles. Então o corpo solta-se e a consciência do corpo torna-se um espaço interior percorrido por movimentos que refletem, à escala microscópica, os movimentos sutis que atravessam os órgãos. (GIL, 2004, p. 23)
\end{abstract}

Para realizar movimentos corporais de instabilidade, ou outros que exijam certa atenção sobre o corpo e sobre o movimento, o ator e o bailarino precisam se concentrar e estabelecer uma consciência sobre o corpo. Assim, através da consciência corporal, eles conseguem acessar os movimentos sutis e internos do corpo. Por meio da percepção desses movimentos sutis, o intérprete elabora um corpo que age além da esfera física, um corpo que age nos movimentos cinestésicos e subjetivos, na esfera virtual, um corpo de poderes virtuais:

O equilíbrio (do corpo) não é portanto, mecânico, físico, mas "virtual", porque é o corpo virtual que dança, não o corpo de carne e músculos. Ou antes: o corpo de carne dançado atualiza o virtual, encarnando-o e desmaterializando-o ao mesmo tempo. (GIL, 2004, p. 24)

O corpo de carne, como Gil define, possibilita, por meio de seus movimentos e gestos físicos e macroscópicos, o acesso a esse outro corpo, um corpo que realiza os movimentos sutis e às vezes invisíveis do corpo, que surge do subjetivo, do cinestésico e do imagético do sujeito. O corpo físico e palpável do ator-bailarino, através de seus movimentos no tempo e no espaço, aciona o corpo dos sentidos, das sensações e das percepções. É através da 
ação que o corpo se atualiza em forças virtuais. A atualização do corpo por forças virtuais acontece por intermédio do agir, que movimenta e modifica o corpo e o espaço ao seu redor. Por meio dessa ação, o ator-bailarino cria os gestos virtuais. Esse processo se realiza através da percepção e da consciência do corpo sobre o próprio movimento; é por meio dela que o gesto se amplifica e o corpo em cena se transforma em uma caixa de ressonância de sensações, imagens e sentidos.

Trata-se de "libertar o corpo" entregando-o a si próprio: não ao corpomecânico nem ao corpo-biológico, mas ao corpo penetrado de consciência, ou seja ao inconsciente do corpo tornado consciência do corpo. (...) O corpo "abre-se", os seus movimentos microscópicos ressoam a uma outra escala de consciência. (GIL, 2004, p. 25)

É pela consciência que os movimentos do corpo se expandem e podem ressoar nessa esfera virtual da qual nos fala Langer (1980), uma esfera de forças que são mais que físicas, são cinestésicas. O corpo se abre para ser um ressonador de gestos e movimentos cheios de poesia e metáforas, podendo ser utilizadas como fonte de criação nas linguagens cênicas contemporâneas, que prezam por uma cena fragmentada, borrada, simbólica e marcada por uma fisicalidade poética.

Nestas encenações, tanto de dança quanto de teatro, em que os elementos técnicos e expressivos são independentes entre si, a necessidade de um corpo cênico que encontra a poesia na fisicalidade se faz presente, para que através dele se crie uma linguagem e uma estética de acordo com a necessidade dos artistas envolvidos. Desta forma, entendemos que o corpo cênico contemporâneo pode ser um corpo ressonador de imagens, metáforas e poesia. Desta forma, ele pode ser um corpo que se desloca nessa esfera de forças virtuais realizando gestos potentes e poéticos, sendo um corpo virtual que reflete uma cena baseada na fisicalidade metafórica, onde a poesia proposta pelos movimentos convidam os espectadores a imaginar.

O jogo de poderes virtuais, manifesta-se nos movimentos de personagens ilusórias, cujos gestos apaixonados preenchem 0 mundo que criam - um mundo remoto, racionalmente indescritivel, em que as forças parecem tornar-se visíveis. Mas o que as torna visíveis não é em si mesmo sempre visual; a audição e a cinestesia sustentam a imagem rítmica, movente, a um tal ponto que a ilusão de dança existe para o bailarino bem como para os espectadores. (LANGER, 1980, p. 205) 
Esse corpo cênico cria ilusão e se desenvolve dentro dessa esfera de forças que são mais do que visíveis, são virtuais, podendo ser um corpo presente tanto no teatro quanto na dança, pois, como já dito no item 1.1., a partir do rompimento das fronteiras entre dança e teatro as encenações contemporâneas requerem um corpo que tenha habilidades físicas e artísticas bem desenvolvidas, um corpo que encontra na fisicalidade seu aporte poético e artístico. Assim, o ator-bailarino se vale da ação, do seu agir, para criar movimentos e gestos com potência artística e estética. Nesse sentido, pode-se dizer que na contemporaneidade temos a figura de um ator-bailarino que, através do gesto, elabora uma linguagem e se comunica por meio dela.

(...) percebe-se que a abstração básica é o gesto virtual, e que esse gesto é tanto um fenômeno visível quanto um fenômeno muscular, isto é, pode ser visto ou sentido. O gesto consciente é essencialmente comunicação, como linguagem. (LANGER, 1980, p. 205)

Se esse ator-bailarino necessita de um gesto consciente para criar linguagem, ele necessita conscientizar o corpo e o movimento e criar o que Gil chama de corpo de consciência.

\subsection{CONSCIÊNCIA DO CORPO OU CORPO DE CONSCIÊNCIA}

Para que a consciência do corpo se torne um corpo de consciência, é necessário que $\mathrm{o}$ ator-bailarino realize um trabalho sobre o corpo com 0 objetivo de reconhecer e desenvolver suas habilidades técnicas e expressivas, como peso, espaço e tempo, e assim acessar o lado intuitivo e subjetivo do seu corpo, tão essencial na criação. Como nos traz Ana Maria Rodriguez Costas (2010) em sua tese de doutorado, nesse processo de despertar a percepção se descobre a subjetividade do corpo: A iniciação de processos exige o olhar atento, cuidadoso frente ao
despertar da percepção e consciência do próprio corpo. Um estar
junto de um processo delicado e comovente: fazer-se testemunha da
descoberta de um sujeito, de uma subjetividade no corpo que dança.
(COSTAS, 2010, p. 12)

Nesse momento, gostaríamos de esclarecer as razões pelas quais acreditamos ser importante acessar a intuição e a sensibilidade durante o processo criativo corporal, partindo das reflexões da artista Fayga Ostrower (19202001) em seu livro sobre processos de criação (2013). Todos os processos 
criativos acontecem no âmbito da intuição, pois são operações que dependem não só do aspecto racional, consciente e objetivo do ser, mas também de seu lado instintivo, subjetivo e sensível, pois é através da sensibilidade que entramos "num permanente estado de excitabilidade sensorial, a sensibilidade é uma porta de entrada das sensações. Representa uma abertura constante ao mundo e nos liga de modo imediato ao acontecer em torno de nós." (OSTROWER, 2013, p. 12). Segundo ela, grande parte de nossa sensibilidade fica restrita ao campo do inconsciente, porém conseguimos organizar e visualizar essa sensibilidade em nosso consciente através de nossas percepções: "a percepção é a elaboração mental das sensações." (OSTROWER, 2013, p. 12).

Sendo assim, a partir do desenvolvimento sobre a consciência do corpo, o ator-bailarino desperta a percepção sobre o próprio corpo, the permitindo realizar inúmeras relações intuitivas e subjetivas que poderão guiá-lo em torno da sua própria expressão e criatividade. Desenvolver as suas habilidades técnico-artísticas é um passo importante na elaboração de sua consciência corporal e, por conseguinte, da sua própria criatividade, pois através dos movimentos corporais e suas dinâmicas o ator-bailarino acessa as possibilidade poéticas de seu corpo.

Como desenvolver essas habilidades? É preciso exercitá-las e treiná-las e para isso existem muitas técnicas e métodos. Ao longo do século $X X$, quando o corpo do ator passou a ser o foco da criação cênica, muitas abordagens e sistemas foram desenvolvidos com o objetivo de treinar e desenvolver qualidades físicas e expressivas do ator, como mencionado no item 1.1. desta dissertação.

Pensando em desenvolver habilidades técnico-artísticas para 0 atorbailarino, partimos da minha experiência como aluna em aulas de dança ${ }^{9}$ com ênfase no Sistema de movimento de Rudolf Von Laban. ${ }^{10}$ Laban foi um grande bailarino austro-húngaro, coreógrafo e teórico da dança que dedicou sua vida ao estudo da linguagem do movimento, como nos diz Louppe (2006, apud

\footnotetext{
${ }^{9}$ Durante os anos de 2009 e 2010, fui aluna do Grupo Experimental de Dança de Porto Alegre, no qual frequentei aulas de diferentes técnicas de dança, como balé, educação somática, dança contemporânea, contato, improvisação e Sistema Laban. Esta experiência encontra-se exposta no capítulo dois desta dissertação.

10 Nosso recorte de estudo e pesquisa do Sistema de Movimento de Rudolf Von Laban, encontra-se exposta nos capítulos 2 desta dissertação.
} 
COSTAS, 2010) um dos "[...] grandes inventores de pensamento do movimento" (p. 36). Ele desenvolveu um importante Sistema de análise do movimento, que serviu de base para muitos artistas e teóricos do movimento ao longo de todo o século $X X$ até os dias atuais. Seu Sistema é amplo e abrange, dentre muitos outros aspectos, o princípio da coreologia (LABAN, 1978), que compreende o estudo sobre o movimento em seus aspectos formais, mentais, sensoriais e emocionais. Entre eles se encontra o princípio corêutica, que investiga o corpo e o espaço, e a eukinética, que aborda os aspectos qualitativos do movimento mais relacionado ao corpo e à expressão. A eukinética compreende o estudo sobre os quatro fatores de movimento, aspetos que se encontram detalhados e esclarecidos no capítulo dois desta dissertação. Assim, a partir de nossa experiência em aulas de dança fundamentadas sobre os quatro fatores do movimento de Laban, espaço, peso, tempo e fluência, percebemos que estes são importantes dispositivos na busca pelo desenvolvimento das qualidades técnico-artísticas do ator-bailarino.

Von Laban faz entrar em jogo uma noção central em sua teoria do movimento: o esforço. Define-o como "impulso interior na origem de todo o movimento", dançado ou não dançado. Quando se trata da dança o esforço contém "qualidades"- tais como peso, o tempo, o espaço e o fluxo -, que variam em quantidade e em intensidade, de tal modo que traçando o quadro de suas combinações possíveis, se obtêm os diversos tipos de movimentos dançados. (GIL, 2004, p. 15)

Ao praticar e exercitar essas qualidades expressivas (peso, espaço, tempo e fluência), o ator-bailarino desenvolve suas capacidades técnicoartísticas, criando distintas combinações de movimentos através das habilidades corporais, estéticas e perceptivas que foram despertadas.

Assim, além das qualidades técnicas físicas trabalhadas, os aspectos sensíveis também precisam ser desenvolvidos, como a sensação e a imaginação, que são ferramentas importantes no auxílio da consciência, percepção e sensibilidade corporal. A partir dessas duas camadas de experiência, física e sensorial, é possível criar gestos virtuais, gestos poéticos que são guiados pelos sentidos do corpo.

Os sentidos ou, melhor dizendo, os sistemas sensoriais são tradutores de atributos que correspondem aos fatores do movimento que Rudolf Laban conceituou, os quais definem suas qualidades expressivas: fator espaço, relacionado à localização; fator esforço/peso, relacionado à intensidade; e o fator tempo, relativo à duração dos eventos. O quarto 
fator do movimento é a fluência, que poderia ser associada, talvez, a como nos dispomos às experiências sensoriais, o quanto controlamos e selecionamos focos e canais sensoriais ou nos deixamos levar pela orquestração dos sentidos. (COSTAS, 2010, p. 44)

Para despertar essa orquestração de sentidos, é necessário desenvolver os aspectos físicos e sensíveis do corpo. Muitos caminhos são possíveis, como o trabalho com estímulos visuais (imagens, objetos), sonoros (música e sons) ou sensoriais. Nessa direção, para realizar um trabalho prático sobre a consciência corporal do ator-bailarino, é preciso escolher um caminho que compreenda, além das habilidades técnicas físicas, um foco na criação a partir da sensação e da imaginação. Sendo assim, encontramos na minha experiência enquanto aluna de graduação ${ }^{11}$ uma possibilidade, pois nesse período tive acesso a aulas sobre a pedagogia de Jacques Lecoq, ${ }^{12}$ ator, diretor e professor teatral francês que desenvolveu a sua pedagogia com base nos princípios do movimento, na observação da natureza, na improvisação e na imaginação como molas propulsoras da criação. ${ }^{13}$ Sua pedagogia é extensa e abrange diferentes estilos de atuação. Minha experiência prática aconteceu no que se refere à metodologia das transferências (LECOQ, 2010), que consiste na transposição para o corpo de elementos (água, ar, fogo, terra), matérias, animais, cores, entre outros; assim, o sujeito é conduzido a expandir suas referências poéticas através do imaginário transposto para o corpo. Com a transposição de diferentes dinâmicas e qualidades, o ator-bailarino amplia sua percepção e seu vocabulário corporal ao experimentar dinâmicas que fogem à representação de um personagem e se relacionam a elementos essenciais e orgânicos da natureza.

(...) a metodologia das transferências, que consiste em apoiar-se na dinâmica da natureza, dos gestos de ação, dos animais, das matérias, para, daí, servir a finalidades expressivas, com o intuito de interpretar melhor a natureza humana. A meta é atingir um nível de transposição teatral, fora da interpretação realista. (LECOQ, 2010, p. 79)

\footnotetext{
${ }^{11}$ Durante os anos de 2006 a 2010, fui aluna no curso de Teatro Bacharelado na Universidade Federal do Rio Grande do Sul. Nesse período, cursei aulas com a professora Inês Alcaraz Marocco, que trabalhava sobre a pedagogia de Jacques Lecoq. Essa experiência encontra-se exposta no capítulo três desta dissertação.

${ }^{12}$ Nosso recorte de estudo e pesquisa da pedagogia de Jacques Lecoq encontra-se exposta no capítulo três desta dissertação.

${ }^{13}$ Estes aspectos encontram-se detalhados e esclarecidos no capítulo três desta dissertação.
} 
Através dessa metodologia, percebemos que 0 ator-bailarino é convidado a expandir suas referências corporais, tendo como estímulo a imaginação. Por meio dessa experiência imagética-sensorial, surgem gestos de ação que são desenvolvidos a partir das dinâmicas da natureza e despertam a percepção do intérprete sobre a expressividade corporal. Na busca pela consciência do corpo e do gesto para a criação artística, a imaginação é um importante veículo na condução à consciência corporal no que se refere a sua disponibilidade expressiva e poética. Assim como o corpo físico, ela é um músculo que também deve ser exercitado e treinado, como nos diz Cláudia Muller Sachs em sua tese de doutorado (2013): "Para que o ator seja capaz de dominar e dirigir o corpo e o espírito, arriscar-se, propor, etc., ele deve exercitar sua imaginação que, assim como os músculos do corpo, é o veículo que conduz a criação". (SACHS, 2013, p. 124).

Com o intuito de desenvolver uma consciência sobre o corpo que possa vir a se tornar um corpo de consciência, um ressonador de metáforas corporais poéticas, constatamos a necessidade de desenvolver as habilidades técnicoartísticas do ator-bailarino, tanto em seus aspectos físicos e expressivos como sensoriais e imaginários. Percebemos que o trabalho sobre os fatores de movimento de Laban colabora para despertar a consciência corporal do atorbailarino, pois amplia suas habilidades ao proporcionar um entendimento específico sobre as qualidades que compõem o movimento nos aspectos de tempo, espaço, peso e fluência. Nesse mesmo sentido, na metodologia das transferências de Jacques Lecoq, o ator-bailarino é convidado a transpor para o corpo as sensações e dinâmicas de cada elemento da natureza, desenvolvendo assim a sua imaginação e sensibilidade. Aqui é importante frisar que entendemos que o trabalho sobre os fatores de movimento também desenvolve a imaginação e a sensibilidade, porém a imaginação trabalhada segundo Lecoq nos instiga de forma muita rica em nossa experiência artística e percebemos ser esta um dispositivo importante na criação, pois desloca o corpo cênico da lógica tradicional, solicitando-o a encontrar novas formas de construção para a expressão poética por meio de diferentes qualidades e dinâmicas, contribuindo para a elaboração de uma lógica interna do corpo. Ambos amplificam a visão e a percepção do ator-bailarino, permitindo que ele 
reconheça em si e no seu corpo capacidades expressivas e sensíveis na realização de sua "viagem interior" (LECOQ, 2010, p. 75) em busca da criatividade e da poesia presente em seus corpos. Percebemos que ambos podem colaborar para amplificar o trabalho técnico-artístico do ator-bailarino, contribuindo e se complementando para o despertar de sua percepção e consciência corporal.

Sendo assim, essas habilidades técnico-artísticas devem ser treinadas com o intuito de despertar a percepção, a sensibilidade e a intuição na construção de uma linguagem poética que é guiada pelos gestos, pela consciência do corpo e pela sensação corporal.

\begin{abstract}
A possibilidade de estarmos atentos às percepções, conectando-nos às sensações oriundas da captação dos sentidos, permite a possibilidade de ocorrerem novas percepções. Nosso mundo existe por que o sentimos, o interpretamos e construímos uma percepção. Sentimos nosso corpo e sentimos nosso ambiente. Dessas sensações construímos um mapa de nosso mundo interno e externo. (COSTAS, 2010, p. 49)
\end{abstract}

Como nos fala Costas (2010), é a partir dos sentidos que podemos captar novas percepções e construir um mapa interno e externo do nosso mundo, e o que é nosso mundo se não o nosso próprio corpo, pois é através dele que conhecemos o mundo e nos reconhecemos nele. Ao refletir sobre a criação com base na poética corporal, acreditamos que é a partir de novas percepções corporais que a criatividade e a poesia acontecem. Nessa direção, novas percepções podem surgir com a construção de um mapa interno e externo do corpo através dos sentidos. Nesta busca, a consciência sobre o corpo pode se tornar um corpo de consciência, como nos sugere Gil, com a possibilidade de elaboração de um mapa da geografia interna e externa de nossos corpos.

Para finalizar este primeiro capítulo, constamos que as reflexões realizadas até aqui se referem a um pensamento sobre o corpo, como nas noções discutidas sobre o corpo de consciência de Gil (2004) e de gestos virtuais de Langer (1980), ou seja, reflexões, importantes em nosso cenário acadêmico, sobre um corpo que é visto e percebido externamente. Porém, como artistas do corpo, precisamos refletir também sobre pensamentos "do/no corpo" (COSTAS, 2010, p. 35), produzidos a partir da vivência e experiência corporal tanto em aulas como em processos de criação ou outros meios que 
nos permitam vivenciar no corpo experiências que se tornam uma reflexão e um pensamento do/no corpo. Como nos fala Costas, a união entre pensamentos sobre o corpo e do/no corpo (COSTAS, 2010, p 35) enriquece nossas percepções, pois um contribui para o outro no exercício de reflexão e produção de conhecimento:

Existe uma produção de pensamento sobre o corpo. Existe uma produção de pensamento do e no corpo. Existe a possibilidade de um enriquecimento de perspectivas quando se associam os pensamentos sobre o corpo aos pensamentos do e no corpo. (...) $\mathrm{O}$ olhar científico para o corpo colabora com artistas e educadores do corpo a visualizar esse conhecimento, quase mesmo um sair do corpo, daquele corpo vivido e percebido. (COSTAS, 2010, p. 35)

Nos próximos capítulos desta dissertação, buscamos realizar o exercício de uma reflexão do/no corpo que nos possibilite experienciar um pensamento sobre o nosso fazer. Desse modo, nos dois próximos capítulos, realizamos a reflexão sobre nossa práxis de trabalho a partir das metodologias de Laban e Lecoq, elaborando uma consciência sobre o corpo com o intuito de estabelecer uma espécie de "mapa" corporal. Esse mapa nos guiou em nossa viagem pessoal na criação de metáforas corporais durante o desenvolvimento de nosso exercício cênico de composição, que se encontra no quarto e último capítulo desta dissertação. 


\section{CAPÍTULO 2 - LABORATÓRIO DE CRIAÇÃO: DESENVOLVENDO O CORPO CÊNICO A PARTIR DE PRINCÍPIOS DO SISTEMA DE MOVIMENTO DE RUDOLF VON LABAN}

Iniciamos esse segundo capítulo partindo da reflexão realizada no capítulo anterior, pois estamos construindo nosso percurso reflexivo a partir de nossa práxis, para assim elaborar a construção de um pensamento do/no corpo (COSTAS, 2010, p. 35). Começamos esclarecendo o campo de nossa experiência, a qual nos possibilitou escolher e desenvolver nossa práxis a partir de princípios do Sistema de movimento de Rudolf Von Laban e da pedagogia de Jacques Lecoq. ${ }^{14}$ É importante pontuar os caminhos de nossa vivência pessoal com essas duas metodologias, sendo que nossa investigação se configura como uma pesquisa qualitativa, pois se baseia na experiência para a construção de conhecimento.

Apresentamos então as referências do Sistema de movimento de Rudolf Von Laban, que nos permitiram intuir os caminhos traçados nesta pesquisa. Nesse momento, se torna relevante falar da experiência prévia da pesquisadora que vos fala com o Sistema de movimento de Laban. Como já mencionamos no primeiro capítulo, durante os anos de 2009-2011 frequentei o Grupo Experimental da Cidade de Porto Alegre. ${ }^{15}$ Nesse período, pude vivenciar aulas de dança de diferentes estilos, passando por balé clássico e dança contemporânea até o Sistema de análise de movimentos Laban, que seguiam pedagogias distintas de acordo com cada professor. Dentro dessa grande gama de variadas abordagens, uma das quais marcou muito meu percurso foram as aulas baseadas no Sistema Laban, ministradas na época pela professora Juliana Vicari. ${ }^{16}$ Ela abordava a aula, entre outros aspectos, a

\footnotetext{
${ }^{14}$ Nosso recorte de estudo e pesquisa, tanto sobre o sistema de movimento de Rudolf Von Laban como a pedagogia de Jacques Lecoq, encontra-se exposto nos capítulos dois e três desta dissertação.

${ }^{15}$ O Grupo Experimental de Dança da Cidade surgiu em 2007 com o objetivo de possibilitar a formação continuada em dança. Idealizado pelo Centro Municipal de Dança, da Secretaria Municipal da Cultura de Porto Alegre, busca criar a oportunidade para jovens complementarem a sua formação em dança e terem maiores oportunidades profissionais na área. Fonte: http://grupoexperimentalpoa.blogspot.com.br/ acessado em 05 de junho de 2014.

16 Juliana Vicari é bailarina, coreógrafa e professora. Graduada em Dança pela UERGS e Especialista em Arte, Corpo e Educação pela UFRGS. Integrante do Grupo Tato, grupo de pesquisa em contato-
} 
partir de princípios de movimento que podiam ser aplicados tanto em composições coreográficas como em movimentos do cotidiano, e inclusive em textos escritos. Estes princípios eram estabelecidos segundo os fatores de movimento de Laban: espaço, peso, tempo e fluxo. Assim, era possível estudar e criar movimentos segundo os aspectos estabelecidos por cada fator, ampliando nossas referências corporais e as possibilidades de movimento que nasciam de nosso próprio corpo sem a necessidade de seguir uma forma préestabelecida à qual o corpo deveria se adequar.

Essa possibilidade foi muito rica, pois ampliou minha percepção corporal, bem como minha sensibilidade para explorar os movimentos que surgiam de meu próprio corpo, reverberando em minhas escolhas estéticas e criativas que se expandiram a partir dessa experiência. Sabemos que esse tipo de experiência é possível através de outras tantas abordagens sobre o corpo e a dança, porém, naquele momento, essa descoberta me foi muito enriquecedora, pois minha trajetória vinha de uma formação dentro de uma faculdade de teatro que abordava o corpo de forma mais restrita ao texto dramático ou à interpretação de personagens. Aquele foi um momento de conhecer meus próprios movimentos e entender que eles em si poderiam criar e construir uma lógica própria e uma linguagem artística sem o intermédio de um texto ou uma forma física pré-determinada por uma terceira pessoa. Esta descoberta foi intensa, ampliando e ressignificando minha percepção, bem como meu entendimento sobre o corpo cênico.

Sendo assim, a partir desse breve relato sobre minha experiência pessoal, acreditamos esclarecer um pouco as razões que nos conduziram a realizar o recorte de nossa metodologia de trabalho a partir do estudo e práxis sobre os quatro fatores de movimento de Laban e os aspectos desenvolvidos a partir deles. Acreditamos relevante salientar que, na investigação sobre o corpo cênico à qual nos propomos, os princípios de movimento desenvolvidos a partir da prática sobre os quatro fatores é muito ampla e pode compreender distintas

improvisação. Indicada ao Prêmio de Melhor Bailarina de 2008 e vencedora do Prêmio de Melhor Coreografia de 2008, ambos pelo espetáculo A3. Em 2009 ganhou a Bolsa Fumproarte para estudar no Instituto Laban/Bartenieff de Estudos do Movimento em Nova lorque, onde obteve o título de Analista de Movimento. Fonte: http://cdancasmc.blogspot.com.br/2011_01_01_archive.html acessado em 05 de junho de 2014. 
abordagens. Em nosso caso, percebemos que é um dispositivo muito eficiente na elaboração de gestos e movimentos tanto no teatro como na dança e que pode ser um veículo de criação muito potente no intercâmbio entre essas duas linguagens, bem como na elaboração de uma fisicalidade poética presente no corpo de cada ator-bailarino.

Desse modo, nesse segundo capitulo, abordamos os aspectos metodológicos de cada fator de movimento presente na práxis de nosso percurso investigativo/criativo. Esses aspectos são abordados através de uma pequena contextualização sobre o Sistema Laban, bem como sobre os quatro fatores de movimento, as ações básicas de esforço e a utilização deles dentro de nossa experiência nos denominados Laboratórios de Criação. O Laboratório de Criação compreende nossa práxis dentro das metodologias abordadas nessa pesquisa e se encontra exposto detalhadamente ao longo deste capítulo.

\subsection{Rudolf von Laban: um breve contexto sobre a experiência}

Rudolf von Laban nasceu em 1879 na Áustria-Hungria e faleceu em 1958 na Inglaterra. Laban foi um grande bailarino, coreógrafo e teórico da dança que dedicou sua vida ao estudo da linguagem do movimento, como já mencionado no capítulo um desta dissertação. Segundo Louppe (2006, apud COSTAS, 2010), um dos "[...] grandes inventores de pensamento do movimento" (p. 36). Ele desenvolveu um importante Sistema de análise do movimento que serviu de base para muitos artistas, pesquisadores e teóricos do corpo e do movimento ao longo de todo o século $X X$ até os dias atuais.

As principais influências de Laban foram os teóricos e pesquisadores do movimento Émile Jacques Dalcroze ${ }^{17}$ (1865-1950) e François Delsarte ${ }^{18}$ (18711911); o primeiro desenvolveu a Euritimia e o segundo elaborou teorias para a

\footnotetext{
17 Émile Dalcroze (1865-1950) nasceu na Suiça e foi um compositor, músico, educador musical e desenvolveu a Euritimia, um método de aprender e vivenciar a música através do movimento. O Método Dalcroze pretende ensinar conceitos musicais através do movimento. Assim, uma variedade de movimentos análogos são utilizados para se relacionar aos conceitos musicais e desenvolver uma sensação integrada e natural para a expressão musical.

${ }^{18}$ François Delsarte (1871-1911) é um reconhecido teórico do gesto e seu trabalho influenciou as bases da educação física, da ginástica, do teatro e da dança. Através da observação do homem e seu cotidiano, relacionou essa observação com o cientificismo para criar uma série de leis e princípios que colaboraram para o desenvolvimento da ginástica rítmica.
} 
ginástica rítmica. Ambos tentaram sistematizar através de princípios alguns fundamentos sobre o movimento e a integração do homem com a expressão e a natureza. Dalcroze, em particular, buscou estabelecer a relação entre o movimento e a música. Segundo Pereira (2007),

(...) a Eurritmia, criada pelo pedagogo suíço Émile Jaques Dalcroze (1865-1950), tinha como objetivo promover um intercâmbio entre as dinâmicas corporais e sonoras em toda a sua extensão e permitir que o aluno aprendesse a associar e a dissociar movimentos, a ordenálos no espaço e a eliminar os movimentos que não viessem a ser utilizados, também era adepto desta revolução e mudança de mentalidade em relação ao gosto e uso da higiene corporal. (PEREIRA, 2007, p. 34)

Imbuído pelos princípios de Dalcroze e Delsarte, Laban desenvolveu um método sobre o movimento corporal e sua relação com qualquer expressão artística, pois acreditava que só através dos movimentos o corpo poderia gerar a energia para a expressão acontecer. Ao longo de sua vida, residiu, pesquisou e criou em diferentes países, como Suíça, Berlim e Inglaterra. Durante o tempo que viveu na Inglaterra, até a sua morte, desenvolveu seus estudos sobre os princípios de movimento com seus alunos e bailarinos, além de realizar um Sistema de exercícios corretivos para operários, que foi utilizado em larga escala em toda a Inglaterra. A partir desse Sistema, Laban pôde analisar e entender a movimentação humana em geral e desenvolveu uma metodologia de análise do movimento.

Ele formulou uma minuciosa análise da composição dos movimentos, que deu origem à coreologia e às denominadas corêutica, estudo do corpo e seus movimentos em relação ao espaço e as formas, e eukinética, estudo das qualidades expressivas do movimento, que estão detalhadas mais adiante neste capítulo.

Contudo, o Sistema de análise de movimento desenvolvido por Laban é muito extenso e abrange outros estudos e conceitos, como a labanotation, que se tornou um importante instrumento de notação de movimentos e composições corporais, no qual o espaço é dividido em três níveis (vertical, horizontal e axial) e sobre os quais se inscrevem as doze direções do movimento. Laban também desenvolveu a denominada dança coral, em que um grande número de pessoas se movia em conjunto segundo uma coreografia de estrutura simples que tinha por objetivo integrar o movimento 
das pessoas de forma colaborativa. Além disso, seu Sistema também abrange representações geométricas, movimentos centrípetos e centrífugos e a consciência de ritmo, espaço e peso.

Sendo assim, percebemos que Laban ampliou muito o entendimento sobre movimento e expressividade; suas teorias foram fundamentais para a compreensão do corpo e do movimento durante todo o século $X X$. Seus princípios de movimentação, tanto na expressão artística quanto na vida cotidiana influenciaram muitas gerações da dança moderna, ${ }^{19}$ das artes cênicas em geral e continua reverberando em artistas, teóricos e pesquisadores até os dias atuais.

Percebemos que, em todo o seu processo criativo, Laban desejava encontrar no corpo movimentos simples e livres que se relacionassem com as expressões pessoais de cada indivíduo. Para ele, o movimento e a dança eram os meios pelos quais o homem poderia dizer o indizível.

A dança revela ao homem suas tendências fundamentais; a partir deste ponto, projeta-o para o futuro, fazendo-o pressentir sua personalidade virtual, que poderia realizar indo até o fundo de suas pulsões. (LABAN, apud BOURCIER, 2001, p. 295)

Nessa direção, a pesquisadora e professora francesa Isabelle Launay (1999) realiza uma relevante reflexão sobre o Sistema de análise de movimento de Laban, destacando, entre outros aspectos, a importância da experiência de corpo e movimento dentro de todo o processo de pesquisa e criação de Laban. Segundo a autora, Laban tem o propósito de descobrir uma corporeidade autêntica fundamentada na experiência e movimento singular de cada pessoa. Esta experiência era um tanto esquecida na Europa do início do século XX devido à crescente modernização e urbanização. Segundo a autora, Laban buscou "(...) fundar uma prática e uma teoria do movimento, como

\footnotetext{
19 A origem da dança moderna se deu em meados do século XIX, por meio de estudos do francês François Delsarte (1871-1911), que induziu relações entre a emoção interior, a voz e o gesto. A dança moderna se diferencia da dança clássica porque o balé aprecia a leveza e a suavidade dos movimentos, enquanto a dança moderna, desde sua origem, busca a manifestação extrema dos sentimentos através dos movimentos corporais. Algumas de suas características são: trabalho corporal por meio de contrações, torções, desencaixes; o eixo dos exercícios está no tronco, no contato, na queda, na improvisação, na respiração, no movimento da coluna e das articulações; diferentes graus de tensão/relaxamento muscular, entre outras. Entre os principais artistas pioneiros da dança moderna, estão François Delsarte (1871-1911), Rudolf von Laban (1879-1958), Isadora Duncan (1877-1927), Martha Graham (1894-1991) e Mary Wigman (1866-1973).
} 
experimentação e saber, para que uma corporeidade inédita surgisse, capaz de responder às transformações da vida moderna" (LAUNAY, 1999, p. 75).

Percebemos, assim, que toda a teoria e Sistema de análise de movimento de Laban foram fundamentados em sua experiência, tanto de vida quanto artística. Ele dedicou toda a sua vida ao estudo e à sistematização da linguagem do movimento em seus diversos aspectos: criação, notação, apreciação e educação. Baseado em suas próprias vivências, ele elaborou uma complexa e inovadora teoria do movimento, construída a partir de suas reflexões e experiências do/no corpo (COSTAS, 2010, p. 35).

Sendo assim, Laban se torna uma referência fundamental nesta pesquisa, pois pretendemos aqui desenvolver um conhecimento a partir da práxis, um conhecimento produzido por meio da experiência e da reflexão do/no corpo. Dessa forma, investigamos as contribuições e apropriações do Sistema Laban para a elaboração de uma linguagem artística fundamentada na fisicalidade singular e poética de cada intérprete. Seguem duas fotografias de alunos e dançarinos de Laban em diferentes experiências.

Figura 5 - Alunos de Laban em experiência de verão Sul do Monte Veritá.

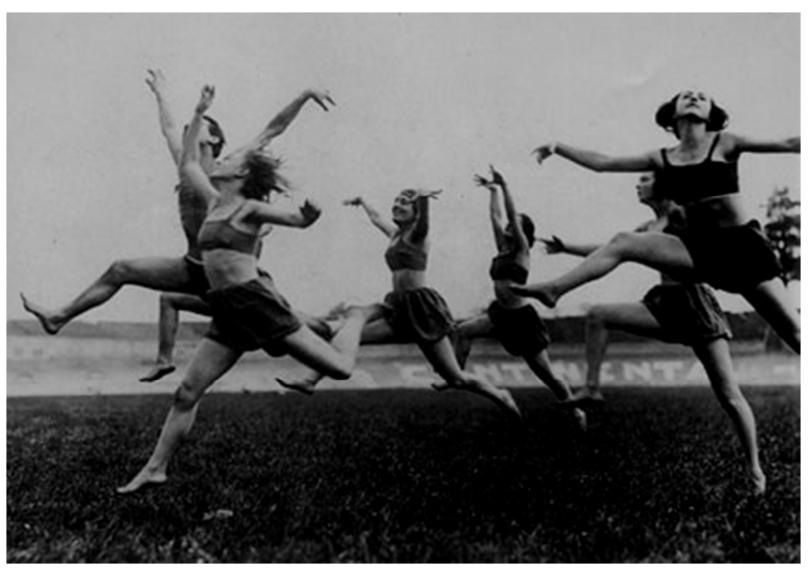

Fonte: http://www.dansehistorie.dk/sider/laban.html. Acesso em 06 de junho de 2014. 
Figura 6 - Dançarinos de Rudolf Von Laban. Berlim 1929.

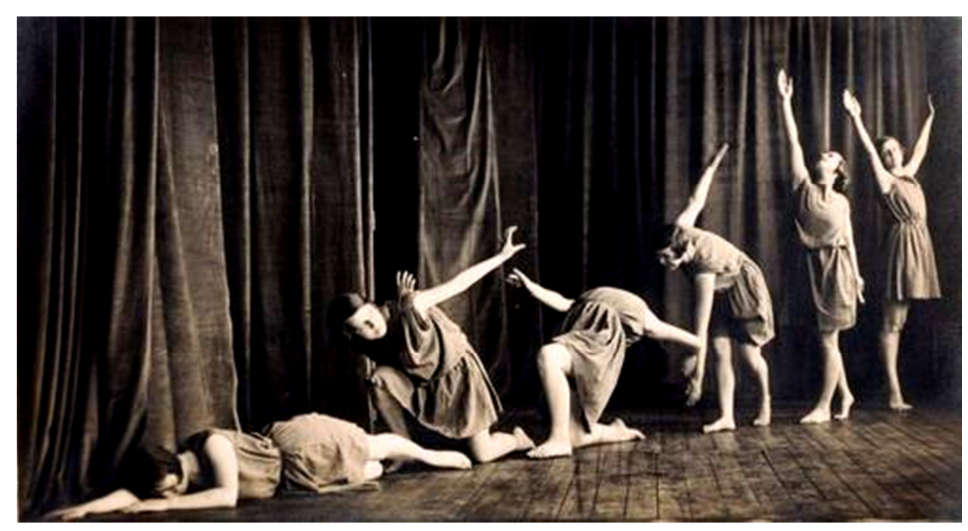

Fonte: http://pansy-purple.rssing.com/chan-1760445/all_p159.html. Acesso em 06 de junho de 2014.

\subsection{Os procedimentos metodológicos de nossa experiência: coreologia, corêutica e eukinética}

O Sistema de análise desenvolvido por Rudolf von Laban, como expomos no tópico 2.1 desta dissertação, é muito amplo e se encontra em diferentes referências, artigos, filmes e livros internacionais e nacionais. No Brasil, muitos foram e são os pesquisadores, artistas e teóricos que abordam e investigam o Sistema Laban. Entre eles, encontramos artistas e pesquisadoras como Lenora Lobo e Cássia Navas (2003), Ciane Fernandes (2002) e Lenira Rengel (2003).

No livro O Teatro do Movimento, por exemplo, Lobo e Navas (2003) realizam uma relevante abordagem sobre o corpo e o movimento através de uma sensibilização da anatomia física e da capacidade motora do corpo. Um dos propósitos que encontramos no livro é a construção de uma autonomia corporal por meio da conscientização sobre os mecanismos que levam à mobilidade e expressividade singular de cada intérprete. Segundo as autoras, elas utilizam o “(...) o método Laban, no sentido de instrumentalizar o artista para a grande tarefa do fazer artístico, principalmente no que se refere ao movimento." (LOBO e NAVAS, 2003, p. 115).

Já em Fernandes (2002), encontramos, entre outros aspectos, uma importante reflexão e estruturação do Sistema Laban, associando a abordagem 
desenvolvida por Irmgard Bartenieff (1900-1982) ${ }^{20}$ e a utilização desse método com alunos da Escola de Teatro da Universidade Federal da Bahia. ${ }^{21}$ Nesse processo, Fernandes (2002) mostra como o Sistema Laban pode ser aplicado na formação de atores com o intuito de conscientizar sobre os princípios de corpo e movimento, que poderão ser utilizados na práxis do trabalho cênico do ator. Segundo a autora, Laban elaborou uma "teoria em movimento" (FERNANDES, 2002) que se tornou fundamental nos estudos e práticas das artes cênicas em geral:

(...) é inegável que as teorias de Laban sobre espaço e dinâmicas do movimento, bem como seu sistema de notação, vêm fornecendo às artes cênicas, e principalmente a dança moderna do século XX, uma via relevante e estimulante para explorações sobre a natureza simbólica e linguística do movimento, assim como para a (re)presentação e (re)construção de memórias corporais e história social. (FERNANDES, 2002, p. 19).

Lenira Rengel (2003), em seu Dicionário Laban, faz uma importante sistematização sobre a teoria de Laban através de 189 verbetes, nos quais realiza a transposição para o português de termos, conceitos, definições e palavras que fundamentam a metodologia de Laban. A sua obra se estabelece sobre os princípios do Sistema de análise de movimento e de sua experiência dentro deste método, tanto como professora em sala de aula como enquanto aluna de Maria Duschenes, ${ }^{22}$ introdutora do método Laban no Brasil. Nesse livro, Rengel (2003) relaciona sua experiência com a reflexão e oferece um suporte que auxilia na leitura de livros de e sobre Laban.

\footnotetext{
${ }^{20}$ Irmgard Bartenieff nasceu na Alemanha e foi discípula de Laban. Por meio de sua experiência com terapia corporal, dança e o método Laban, elaborou uma metodologia de princípios e práticas corporais que foram a base para desenvolvimento do Sistema Laban/Bartenieff, que consiste num profundo treinamento do olhar para a movimentação humana.

21 Ciane Fernandes iniciou em 1998 o projeto de pesquisa denominado Formação Corporal do Ator: Utilização teórico-metodológica de elementos da dança-teatro para a exploração e sistematização dos procedimentos pedagógicos referentes às técnicas de corpo para a cena em uso na Universidade Federal da Bahia. O projeto, apoiado pelo Programa Institucional de Bolsas de Iniciação Científica pelo período de 2 anos, dividiu-se em duas fases: aplicação do Sistema Laban/Bartenieff nas disciplinas de Técnica de Corpo para a Cena I a IV, sistematizando o conteúdo programático (1998-1999) e a aplicação do treinamento em atividades espetaculares da Escola de Teatro da UFBA (1999-2000). (FERNANDES, 2002).

22 Maria Duschenes (1922) nasceu em Budapeste, na Hungria. Durante os anos de 1937-1939, realizou seus estudos de dança e movimento na Inglaterra com Rudolf Von Laban. Em 1940, devido à Segunda Guerra Mundial, veio residir no Brasil e se tornou uma importante e fundamental difusora do método Laban no país, oferecendo formação prática e teórica sobre Sistema Laban a inúmeros e importantes profissionais da área. Desde 1999, teve que interromper progressivamente seu trabalho devido ao estado de saúde agravado pela doença de mal de Alzheimer. Elaborado com referência no texto Mundo em Movimento, de Inês Bogêa, acessado em 25/05/2014: http://www.inesbogea.com.br/biografia_MariaDuschenes.pdf.
} 
Para a estruturação dos conceitos e métodos utilizados em nossa investigação e práxis, nos baseamos em duas referências bibliográficas específicas: Domínio do Movimento, livro de Rudolf von Laban organizado por Lisa Ullmann ${ }^{23}$ (1907-1985) que teve sua tradução para no Brasil em 1978; e no Dicionário Laban, de Rengel (2003). Com base nessas referências, constatamos que o Sistema Laban se fundamenta sobre o princípio da coreologia, que compreende o estudo sobre os conhecimentos práticos do movimento em seus aspectos formais, mentais, cinéticos, sensoriais e emocionais.

Coreologia é a lógica ou ciência da dança, a qual poderia ser entendida puramente como um estudo geométrico, mas na realidade é muito mais do que isso. Coreologia é uma espécie de gramática e sintaxe da linguagem do movimento que trata não só das formas externas do movimento, mas também do seu conteúdo mental e emocional. Isto é baseado na crença que movimento e emoção, forma e conteúdo, corpo e mente são uma unidade inseparável (RENGEL, 2003, p. 36)

A coreologia abrange dois grandes campos de investigação: a corêutica e a eukinética. Dentro do Sistema Laban, a corêutica é o estudo do movimento no espaço, tanto em relação ao corpo como ao espaço que o circunda.

A Corêutica trata do estudo das formas espaciais dentro da cinesfera e inclui a organização espacial da cinesfera e o modo pela qual as formas lógicas e/ou harmônicas, encontradas nesta organização, são materializadas no corpo do agente. Corêutica trata do espaço no corpo e do corpo no espaço. Espaço no corpo é tomar o corpo e/ou partes dele como ponto de referencia direcional, e definir lugares no espaço a partir do corpo. Corpo no espaço é tomar o espaço (de um quarto, um palco, um jardim) como referencia direcional para o corpo. (RENGEL, 2003, p. 50)

Através de exercícios práticos sobre o espaço, podemos estudar a corêutica. Partimos sempre do corpo como território espacial individual e sobre os princípios de níveis, planos, direções, dimensão, formas e volume. Este território individual espacial pode ser entendido como a cinesfera, que compreende, segundo Laban (1978), "a esfera em torno do corpo", que pode atingir sua extensão máxima através da amplitude dos movimentos corporais nesse espaço. Segue a imagem da cinesfera, que pode ser utilizada como material palpável ou como uma imagem visual e cinestésica para o trabalho criativo do ator-bailarino.

\footnotetext{
${ }^{23}$ Lisa Ulmann (1907-1985), nasceu em Berlim e foi bailarina, coreógrafa e professora; realizou sua formação com Rudolf von Laban na Alemanha. Na década de 1940, na Inglaterra, fundou junto com Laban o Laban Center Institute, que realiza a formação de estudantes dentro do Sistema Laban até os dias de hoje. Foi diretora desta escola até 1973 e nos últimos anos de sua vida se dedicou à organização e catalogação da obra de Laban.
} 
Figura 7 - Esta figura representa a cinesfera elaborada por Rudolf von Laban.

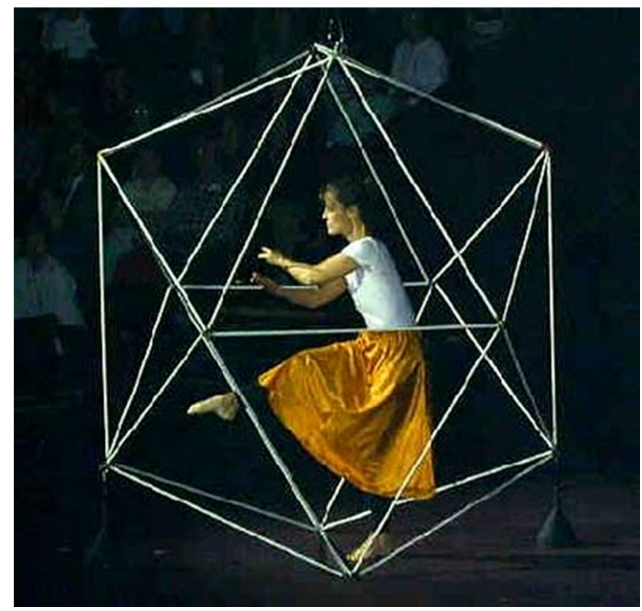

Fonte: Imagem sem autor, retirada do site: http://www.marianolatindance.com.ar. Acesso em 12 de maio de 2013.

A eukinética abrange $o$ estudo das qualidades e dinâmicas do movimento e se relaciona com os aspectos expressivos do movimento. No que diz respeito à cinética, à sensação e à intenção, todo esse estudo está fundamentado no conceito de esforço elaborado por Laban. Para compreendemos melhor essas terminologias, se fez necessário conhecer o que Laban define por esforço:

\begin{abstract}
A fim de discernirmos a mecânica motora intrínseca ao movimento vivo, no qual opera o controle intencional do acontecimento físico, é útil denominarmos a função interior que dá origem a tal movimento. A palavra empregada aqui com esse sentido é esforço. Todos os movimentos humanos estão dissoluvelmente ligados a um esforço o qual, na realidade, é seu ponto de origem e aspecto interior. 0 esforço e a ação dele resultante podem ambos ser inconscientes e involuntários, mas estão sempre presentes em qualquer movimento corporal. (LABAN, 1978, p. 52)
\end{abstract}

Sendo assim, para Laban, todos os movimentos físicos têm origem em uma função interior, que pode ser consciente ou não, e encontra forma através da dinâmica, da sensação e da expressão dos movimentos. Através do corpo podemos dar forma física e expressiva para esse esforço utilizando os denominados fatores de movimento: espaço, tempo, peso e fluência. Por meio deles, acessamos o material palpável para variar as qualidades cinéticas e expressivas dos movimentos.

O esforço e sua concretização através do corpo, da plasticidade e da forma dos movimentos e gestos estão na base dos princípios da corêutica e 
eukinética. Esta ligação entre esforço e forma deu origem ao denominado Sistema effort/shape ${ }^{24}$ (esforço e forma). Este Sistema permite analisar as dinâmicas e qualidades do movimento utilizando os quatro fatores de movimento (peso, espaço, tempo e fluência) por meio de um método de descrição e anotação dos movimentos.

Estes quatro fatores foram identificados por Laban nos movimentos corporais individuais e na própria natureza e apresentam qualidades expressivas que são representadas por dois elementos extremos de atitude. 0 fator peso se relaciona com uma atitude mais relaxada ou enérgica; o fator espaço se relaciona com uma atitude suave ou firme; o fator tempo se relaciona com uma atitude sustentada ou súbita; o fator fluência se relaciona com uma atitude livre ou controlada (LABAN, 1978). No Sistema effort/shape temos a possibilidade de analisar os quatro fatores a partir de um gráfico que corresponde às qualidades que compõem cada um. Segue o gráfico do Sistema effort/shape, onde $\mathrm{P}=\mathrm{Peso}, \mathrm{E}=$ Espaço, F= Fluência e T= Tempo.

Figura 8 - Gráfico referente aos fatores de movimento dentro da representação gráfica do Sistema effort/shape

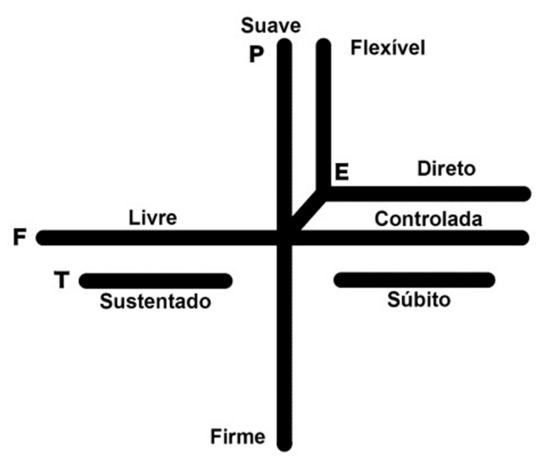

Fonte: Gráfico retirado do livro Domínio do movimento, de Laban (1978).

Este Sistema se fundamenta na relação do esforço e a sua concretização física e cinética e expressiva no corpo através dos quatro fatores

\footnotetext{
${ }^{24}$ O Sistema effort/shape foi desenvolvido por Laban em parceria com o professor inglês Warren Lamb (1923). Ele relacionou shape (forma) e effort (esforço) aos princípios e estudo de Laban apresentadas no livro Choreutics (1966).
} 
de movimento por meio da descrição e anotação ${ }^{25}$ desses fatores. Dessa forma, a qualidade e plasticidade dos movimentos e gestos são o resultado da combinação entre o esforço e as atitudes de cada fator presentes nas ações humanas que compõem cada movimento.

Podemos assim investigar o que Laban (1978) denominaria como "alfabeto da linguagem do movimento", estabelecido com base nos padrões corporais individuais. Através do estudo sobre os fatores de movimento, podemos combiná-los em nosso corpo para depois utilizá-los como material artístico e criativo. Essa investigação sobre os fatores é individual e depende dos padrões corporais, cinéticos, expressivos e sensoriais de cada corpo, pois é através deles que identificamos e visualizamos uma fisicalidade particular que nasce dos gestos e movimentos singulares de cada ator-bailarino.

\begin{abstract}
Enquanto que os movimentos dos animais são instintivos e basicamente realizados em resposta à estimulação exterior, os do homem encontram-se caracterizados por qualidades humanas; por intermédio deles, o homem se expressa e comunica algo do seu interior. Tem ele a faculdade de tomar consciência dos padrões que seus impulsos criam e de aprender a desenvolvê-los, remodelá-los e usá-los. (LABAN, 1978, p. 112)
\end{abstract}

Este ponto é muito relevante em nossa pesquisa, que investiga justamente a percepção e conscientização do corpo cênico na elaboração de uma linguagem artística fundamentada na fisicalidade poética de cada intérprete. Em nossa experiência, investigamos o corpo e os movimentos com base no princípio de esforço presente na eukinética e enfatizamos nossa práxis sobre os quatro fatores de movimento, as ações básicas de esforço, ações incompletas e os ímpetos de ação. Esse processo encontra-se exposto a seguir.

\title{
2.3 Laboratório de Criação: estruturação de nossa experiência, objetivos e rotina
}

A práxis de nossa investigação foi elaborada em nosso Laboratório de Criação, que teve por objetivo realizar uma experiência prática fundamentada em exercícios corporais e dinâmicas identificados no Sistema Laban no que se

\footnotetext{
${ }^{25}$ Não iremos abranger o tópico "notação" nesta dissertação, visto que esta pesquisa não abarca a relação gráfica e o método de registro dos quatro fatores, mas sim a sua descrição e o estudo de suas qualidades cinéticas e expressivas.
} 
refere ao nosso recorte de pesquisa sobre os quatro fatores de movimento. $\mathrm{O}$ Laboratório de Criação se fundamentou em procedimentos lógicos que se constituíram em nossa rotina de trabalho e nos possibilitaram experienciar aspectos cinéticos, cinestésicos, plásticos e visuais no corpo de cada intérprete. Segundo a artista e pesquisadora Cecília Salles (2011), a rotina se relaciona com os modos de ação do artista, seu método de trabalho e aos procedimentos lógicos que são identificados ao longo do processo.

Estamos nos referindo a método como série de operações lógicas responsáveis pelo desenvolvimento da obra: procedimentos lógicos de investigação. (...) O método, sob esta perspectiva, diz respeito, portanto, às diferentes formas de raciocínio desenvolvidas em toda $\mathrm{e}$ qualquer ação do artista. (SALLES, 2011, p. 66-67)

Nossos procedimentos se referem à nossa metodologia dentro das sessões de trabalho, com os sujeitos envolvidos e na ordem em que nossas investigações aconteceram. Sendo assim, vamos agora expor como cada um desses procedimentos se estruturaram dentro de nossa rotina.

No Laboratório de Criação, contamos com a participação de duas pesquisadoras e atrizes-bailarinas: a pesquisadora desta dissertação que vos fala e uma pesquisadora voluntária, Sissi Betina Venturin, ${ }^{26}$ que fez parte de toda a práxis de nossa investigação. A necessidade de trabalhar com uma parceira de pesquisa surgiu após identificar os aspectos metodológicos que pretendíamos investigar, pois percebemos que a presença de outra pessoa seria de grande colaboração para a estruturação de nossos procedimentos práticos, bem como para avaliar as descobertas sobre a fisicalidade singular de cada intérprete. No item denominado Anexos desta dissertação encontram-se três entrevistas realizadas com a pesquisadora voluntária ao longo de todo nosso processo investigativo/criativo.

Nossas sessões de trabalho aconteceram duas vezes por semana ao longo de um ano, com encontros semanais em uma das salas do Departamento de Artes Cênicas da Escola de Comunicação e Artes da Universidade de São Paulo. O trabalho se desenvolveu através de nossa práxis

\footnotetext{
${ }^{26}$ Sissi Betina Venturin é atriz formada em Teatro: Licenciatura pela Universidade Estadual do Rio Grande do Sul (UERGS). Atualmente vive em São Paulo e é integrante do Coletivo Âmago, que pesquisa a dança, o teatro e o cinema em relação com espaços públicos.
} 
sobre os quatro fatores de movimento identificados no Sistema Laban. Nesse processo, estabelecemos a seguinte metodologia:

1. Exploração livre dos fatores de movimento (peso, espaço, tempo e fluência): nesta etapa, o trabalho se realizou através de uma improvisação corporal dentro das atitudes e aspectos estipulados por cada fator e, posteriormente, por cada uma das ações básicas de esforço, ações incompletas e dos ímpetos de ação; ${ }^{27}$

2. Estruturação de uma sequência de movimentos para cada uma das ações básicas de esforço, ações incompletas e dos ímpetos de ação: após a improvisação, selecionávamos o material investigado e 0 estruturávamos em uma pequena sequência de movimentos dotada de uma lógica própria e de um percurso espacial com início, meio e fim.

3. Transmissão e aprendizado das sequências de movimentos individuais: após estabelecer a estrutura da sequência de movimento, cada uma das atrizes-bailarinas transmitia e aprendia a sequência da outra.

Ao final de cada sessão de trabalho, registrávamos as sequências de movimento por meio de filmagem com uma câmera de vídeo e também através do diário de campo da pesquisadora que vos fala, Kalisy Cabeda. Esta foi a metodologia de pesquisa utilizada ao longo de todo o nosso Laboratório de Criação, tanto no que se refere ao Sistema Laban como à pedagogia de Lecoq, que se encontra detalhada no capítulo três desta dissertação.

Aqui acreditamos ser relevante definir o que entendemos por improvisação, já que foi através da improvisação que fundamentamos e estruturamos nossas investigações. Para nossa metodologia, utilizamos a noção de improvisação segundo a professora e pesquisadora Launay (1999). Para a autora, a improvisação em Laban acontece por meio de uma experiência de dança que se dá entre o esquecer e o rememorar no corpo e em seus fluxos de movimento:

Improvisar para Laban é, de um mesmo movimento, buscar e encontrar, decompor e unificar, esquecer e rememorar, mas, sobretudo, não se lembrar. Pois o passado não saberia estar relegado á lembrança, múmia que aniquila a impressão, ou a desintegra. Improvisar é se dedicar a esquecer, para se dar a chance

\footnotetext{
${ }^{27}$ Cada uma dessas ações encontra-se explicada nos itens 2.5, 2.5.2 e 2.5 .3 deste capítulo.
} 
de ver afluir as múltiplas possibilidades de sua mobilidade. (LAUNAY, 1999, p. 32).

A partir desse esquecimento, dessa experiência de movimento que dá acesso a uma mobilidade íntima fruto da vivência singular de cada atorbailarino, que nos baseamos para realizar as investigações e improvisações dentro de nossa metodologia. A seguir, encontra-se exposta a práxis dentro do Laboratório de Criação e nossa investigação sobre os fatores de movimento, ações básicas de esforço, ações incompletas e os ímpetos de ação.

\subsection{Laboratório de Criação: nossa experiência sobre os quatro fatores de movimento}

Nosso Laboratório de Criação seguiu a rotina descrita no item 2.3 deste capítulo e iniciou com o estudo do fator espaço. O fator espaço se relaciona com a atitude de atenção, pois tem conexão com onde o movimento se realiza no espaço. Essa atenção pode ser direcionada tanto para um único foco, espaço direto, ou para muitos focos, espaço flexível.

Espaço direto: é quando nos movemos no espaço com um foco definido e direto, assim os movimentos são mais cruzados, fechados, retos e lineares. Os movimentos são mais limitados no espaço e, consequentemente, mais objetivos, mantendo atenção em único foco. Sua trajetória é mais periférica. O espaço direto traz uma sensação de estreiteza ao movimento. Exemplo: movimentos mais retos, lineares e angulares, como deslocar o corpo todo ou parte dele em uma única direção.

Espaço flexível: é quando nossa movimentação é mais ampla no espaço, pois o foco de atenção é multifocal, assim os movimentos são mais flexíveis, torcidos e abertos. O espaço mais amplo abre as possibilidades do corpo se expandir através das articulações para muitas direções. Desta forma, os movimentos são abrangentes e sua trajetória é mais maleável. O espaço flexível traz ao movimento uma sensação de estar ocupando muitas direções ao mesmo tempo. Exemplo: movimentos compostos por linhas torcidas e ondulantes, como quando movimentamos o corpo e suas partes em diferentes direções simultaneamente. 
Além das atitudes da eukinética relacionadas ao espaço (direto e flexível), abordamos esse fator também sobre o princípio da corêutica, que estuda o corpo no espaço em suas formas e direções. Investigamos alguns aspectos da corêutica, como direções no espaço (frente, atrás, lado esquerdo, lado direito), níveis (alto, médio, baixo), planos (porta, mesa, roda) e a cinesfera, relacionando-os com as atitudes espaciais (direto e flexível) e suas possibilidades de variação.

Direção: as direções, no Sistema Laban, indicam onde os movimentos se localizam no espaço. São muitas as possibilidades de estudar as direções no espaço, como o estudo do poliedro e das vinte sete direções espaciais. ${ }^{28}$ Em nossos estudos, centralizamos o trabalho sobre as trajetórias espaciais relacionadas às direções alto, baixo, esquerda, direita, frente e atrás.

Planos: os planos são a união de uma ou mais dimensões vertical, horizontal e sagital, as quais Laban denominou porta, mesa e roda, para facilitar a sua compreensão através de imagens visuais. O plano da porta, vertical, é a união entre a altura e a largura; o plano da mesa, horizontal, é a união entre largura e profundidade, enquanto o plano da roda, sagital, corresponde à união da profundidade e da altura.

Cinesfera: o princípio da cinesfera compreende, segundo Laban, uma esfera imaginária em torno do corpo na qual o ator-bailarino realiza seus movimentos no espaço. Esse princípio se encontra detalhado no item 2.2 deste capítulo.

Assim, o fator espaço foi investigado de diferentes formas, primeiramente pelo trabalho sobre as partes do corpo e suas diferentes possibilidades de deslocamento e direção no espaço. Esse trabalho proposto por Laban nos trouxe a sensação de liberdade de movimento a partir do reconhecimento das possibilidades corporais dentro da estrutura das direções no espaço.

Percebemos que encontramos uma liberdade de movimento, muito importante, pois o corpo se guiava pelas direções e as formas e sequências surgiam a partir da liberdade que o corpo encontrava,

\footnotetext{
28 "As vinte sete direções espaciais formam a orientação espacial discriminada por Laban. As direções indicam locações (lugares no espaço) de mesmo nome. Em relação ao corpo do agente, a sensação é que estas direções são irradiadas a partir do centro do corpo." (RENGEL, 2003, p. 28)
} 
dentro das infinitas possibilidades de direção que podemos explorar. Sentimos uma liberdade muito grande ao mesmo tempo em que ampliamos as possibilidades de deslocamento e movimentação. Diferentes dinâmicas e propostas, tudo é possível qualquer direção entre TERRA-CÉU. (Diário de campo de Kalisy Cabeda, segundo semestre de 2012) ${ }^{29}$

Em nosso processo, investigamos, além das direções no espaço (frente, atrás, lado esquerdo, lado direito), a sensibilização das articulações e da gravidade a partir da divisão do tronco em cabeça, peito e quadril. Percebemos que ao trabalhar essas partes do corpo com certa autonomia, os movimentos ganhavam independência e o trabalho acontecia com mais naturalidade e maior fluidez (dinâmica) no tempo e espaço.

Para a investigação sobre a cinesfera, dividimo-la em três possibilidades: cinesfera pequena (alcance próximo ao corpo), cinesfera média (alcance médio no espaço) e cinesfera grande (grande expansão do corpo no espaço). Percebemos um aspecto interessante: a partir da ideia de trabalhar o espaço utilizando a imagem visual da cinesfera, movemos o corpo e o espaço externo a ele de forma direta e/ou indireta. Assim, quando temos a intenção de mover o espaço em torno do nosso corpo, o movimento ganha mais qualidade, volume, peso e dinâmica. Recordo aqui de uma fala de Profa. Dra. Sayonara Pereira $^{30}$ (2012) nos encontros do LAPETT/ECA-USP (Laboratório de Pesquisa e Estudos em Tanz Theatralidades):

Vocês têm que parar de fazer o movimento para vocês mesmos, olhem para fora, expandam o corpo, assim vocês saem do lugar seguro de vocês e o movimento ganha espaço, força, gordura. (PEREIRA, 2012)

Ao olhar para fora (espaço externo), olhamos para dentro (corpo) e viceversa, esses são movimentos opostos e complementares referentes ao espaço e que, quando acionados, enriquecem e preenchem o espaço de qualidades corporais e o corpo de qualidades espaciais. Porém, precisamos conscientizar essa qualidade para acessá-la no momento da execução do movimento, tarefa muitas vezes difícil, mas possível na medida em que praticamos e estudamos

\footnotetext{
${ }^{29}$ Diário de campo do trabalho prático desta pesquisa (10/09/12).

30 Sayonara Pereira, orientadora desta pesquisa de mestrado, é professora efetiva e pesquisadora da Escola de Comunicações e Artes da Universidade de São Paulo e diretora do LAPETT (Laboratório de Pesquisa e Estudos em Tanz Theatralidades) (CAC/ECA/ USP).
} 
no corpo esses procedimentos. Desta forma, ao estruturar nossas sequências de movimento sobre o fator espaço, conscientizamos os trajetos realizados pelo corpo, tornando-se mais fácil acessar e visualizar a cinesfera e a sensação de mover o espaço e, consequentemente, o movimento adquire outras qualidades, sensações e imagens.

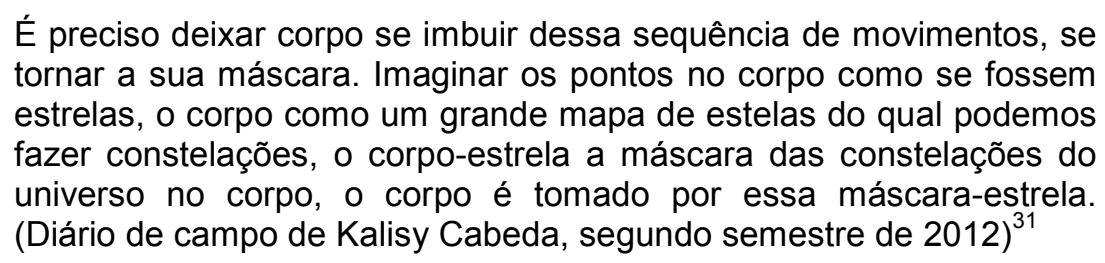

Ao finalizar a exploração sobre o fator espaço a partir dos aspectos da corêutica e eukinética, foi possível perceber que as qualidades do espaço são definidas a partir do foco que colocamos nele e em suas direções e dimensões, resultando em movimentos que ora são mais retos e lineares, ora são mais torcidos e amplos, conferindo-lhes qualidades plásticas. $O$ estudo sobre o fator espaço ampliou a nossa mobilidade corporal, assim como as nossas possibilidades mover e direcionar o corpo no espaço.

\subsubsection{Laboratório de Criação: investigação sobre o fator peso}

O segundo fator que investigamos foi o peso, que se refere à nossa resistência e relaxamento muscular em relação à gravidade. A atitude presente neste fator é a intenção, pois informa o quê do movimento e se relaciona com os aspectos físicos da qualidade do movimento. Ao relaxar o corpo em direção à força da gravidade, permitimos que ele adquira uma qualidade suave e leve do movimento, enquanto na resistência contra a força da gravidade adquirimos uma qualidade firme e forte em nossos movimentos. O corpo se movimenta nas possíveis variações de intensidade entre o peso suave e o peso firme.

Peso firme: é a relação do corpo em resistência à força da gravidade, assim realizamos movimentos mais firmes e fortes no espaço. Ao executarmos dinâmicas corporais fortes, fornecemos condições de sustentação para o corpo, pois produzimos uma resistência interna que gera uma tensão nos movimentos realizados no espaço e isso proporciona uma sensação pesada ao

\footnotetext{
${ }^{31}$ Diário de campo do trabalho prático desta pesquisa (17/09).
} 
movimento. Exemplos: movimentos firmes e com tenacidade, como quando realizamos movimentos que exercem força contra a gravidade.

Peso suave: é o peso passivo do corpo em relação à força da gravidade, assim realizamos movimentos suaves e leves no espaço. Ao ceder à força da gravidade, produzimos uma condição de relaxamento no corpo, pois realizamos uma resistência interna mínima que proporciona movimentos suaves no espaço, estabelecendo uma sensação de ausência de peso, de leveza. Exemplos: movimentos leves, suaves e relaxados, como quando realizamos movimentos que cedem à força da gravidade.

$\mathrm{Na}$ exploração sobre o fator peso (firme e suave), percebemos que para trabalhar com a gravidade é importante nos referirmos à resistência e relaxamento, pois assim adquirimos uma boa compreensão sobre o peso, entendendo que peso não tem a ver necessariamente com pesado ou leve e que é possível variar as velocidades: o peso firme não precisa ser lento e o peso suave não precisa ser rápido. Constatamos que o centro de leveza (parte superior do corpo) realiza melhor a qualidade suave, enquanto o centro de gravidade (parte inferior do corpo) realiza melhor o peso firme. Ao relacionarmos o fator peso com o apoio do corpo no chão, percebemos que quanto maior o ponto de apoio, maior é o peso que está relaxado, e quanto menor o ponto de apoio, o peso necessita estar mais sustentado. Para levantar do chão, necessariamente existe um ponto de apoio e de levantamento de peso, pois levantar o peso está relacionado com apoio e sustentação.

Ao longo do processo de exploração, tanto do fator espaço como do fator peso, percebemos que o início do trabalho era normalmente mais formal e sistematizado, mas com o passar do tempo o próprio corpo começava a ser imbuído por esses fatores e encontrava caminhos que não passavam necessariamente pela intenção mental de qual fator estava sendo utilizado em cada movimento. Percebemos que o próprio corpo criava uma autonomia nesse processo que independia da escolha consciente sobre cada atitude (suave e firme). Assim, no que diz respeito ao fator peso, percebemos que as qualidades suave e firme podem acontecer simultaneamente, sucessivamente e independentemente nos movimentos corporais que normalmente são compostos por essas duas qualidades e suas gradações de intensidade. Definir 
essas descobertas dentro de uma sequência de movimentos foi muito importante para conscientizar as qualidades de movimento que encontramos em cada fator estudado.

Deixar que o movimento venha de dentro do corpo não tentar controlar e comandar, ter consciência do que está fazendo, mas não realizar uma construção mental anterior deixar o corpo apontar os caminhos. Deixar os impulsos internos (esforço) saírem e aos poucos ter uma consciência deles, e ir domando esses caminhos, a potência da natureza artística que é também pessoal. Deixar essa força se manifestar para poder conhecê-la, dominá-la, conscientizá-la em uma sequência e exercita-la na criação. (Diário de campo de Kalisy Cabeda segundo semestre de 2012)

\subsubsection{Laboratório de Criação: investigação sobre o fator tempo}

O próximo fator que investigamos foi o tempo, que se relaciona com as questões de velocidade e duração do movimento. A atitude referente ao tempo é a decisão, pois indica quando o movimento acontece. O fator tempo apresenta duas qualidades: súbito e sustentado, e os movimentos corporais se realizam nas possibilidades de variação entre essas duas qualidades.

Tempo súbito: ocorre quando o movimento apresenta uma velocidade rápida e uma duração curta, na qual a aceleração ocorre de forma repentina e breve. O tempo súbito proporciona movimentos com uma aceleração rápida, curta no tempo e com uma sensação de instantaneidade. Exemplo: movimentos acelerados e curtos, como quando realizamos movimentos pequenos e rápidos.

Tempo sustentado: ocorre quando o movimento apresenta uma velocidade lenta e uma duração longa, ocorrendo uma desaceleração prolongada. O tempo sustentado proporciona movimentos desacelerados e lentos e uma sensação longa no tempo, de permanência. Exemplos: movimentos longos e desacelerados, como quando realizamos movimentos extensos e duradouros.

Em nossos estudos sobre o fator tempo (súbito e sustentado), percebemos que é necessário estudar os movimentos e o corpo dentro de um ritmo pessoal e constante, que podemos estabelecer para nós próprios, e também trabalhar a habilidade do corpo de acompanhar ritmos variados (sons, 
ruídos, músicas), pois é importante desenvolver as diferentes dinâmicas que o tempo possui e que podem determinar as qualidades de um movimento.

Nesse sentido, percebemos que, dependendo da velocidade exercida ao executar uma sequência, podemos alterar a qualidade cinética e cinestésica do movimento, deixando ora mais sustentado, o que traz uma sensação de densidade e de continuidade, ora mais súbito, o que traz uma sensação de instantaneidade e brevidade. Notamos que a mudança de ritmo também gera uma sensação pessoal e íntima no corpo que pode se refletir em diferentes dinâmicas de movimentos e gestos presentes na fisicalidade singular de cada intérprete. Além desses dois pontos, compreendemos a utilização da pausa como um elemento de percepção, controle e concentração do movimento corporal realizado. Na pausa, o corpo estabelece uma estrutura que pode ser observada e conscientizada.

A pausa contém o passado (o que foi), o presente (o que é) e o futuro (o que vai ser) em relação ao movimento, pois na pausa o corpo reverbera a energia do que foi e se prepara para iniciar e continuar o movimento. A pausa enquanto potência. (Diário de campo de Kalisy Cabeda, segundo semestre de 2012) ${ }^{32}$

\subsubsection{Laboratório de Criação: investigação sobre o fator fluência}

O último fator que investigamos foi a fluência, que diz respeito à liberação ou não do fluxo do movimento. Todo movimento apresenta um fluxo natural que se relaciona com seus impulsos internos, ${ }^{33}$ seu esforço (Laban, 1978), e se concretiza nos movimentos, gestos e ações do corpo. A atitude que determina a fluência é a progressão, pois traz como o movimento é realizado, não dizendo respeito nem à direção, nem à velocidade ou à força. A fluência pode apresentar duas qualidades: livre e controlada.

Fluência livre: é quando o movimento apresenta uma liberação do seu fluxo que dificilmente é interrompida, produzindo uma qualidade fluída e livre. Através dessa liberdade, o movimento produz uma sensação de fluidez que

\footnotetext{
32 Diário de campo do trabalho prático (08/10/12).

${ }^{33}$ Para nos referirmos à função interior, a esse esforço que, segundo Laban, acontece dentro do corpo antes de qualquer movimento, vamos utilizar ao longo desta dissertação os termos impulsos internos ou movimentos internos, pois esses termos já eram parte de nossos vocabulários físicos e expressivos e se tornaram presentes ao longo de todo nosso processo investigativo.
} 
auxilia na expansão e emissão dos impulsos internos em movimentos e gestos corporais. Exemplos: movimentos expandidos e fluídos; quando realizamos movimentos com pouca tensão muscular e mais soltos no espaço.

Fluência controlada: quando o movimento apresenta uma contenção do seu fluxo que pode ser interrompida fácil e constantemente, produzindo uma qualidade controlada e cortada. Por meio da contenção dos impulsos internos, o movimento produz uma sensação de pausa que obstrui os fluxos livres do movimento, tornando-os mais restritos, limitados e contidos. Exemplos: movimentos conduzidos e retraídos; quando realizamos movimentos com mais tensão muscular e maior limitação no espaço.

Durante a exploração do fator fluência, percebemos que na qualidade da fluência livre os movimentos são levados em direção à gravidade e se modificam segundo ela, pois a resistência corporal contra a gravidade acaba sendo menor na medida em que o corpo se deixa levar pelos seus fluxos de movimento, assim os movimentos são mais soltos. A fluência controlada se relaciona com a resistência do corpo em relação à gravidade e isso cria certa qualidade no movimento e no espaço em torno do corpo.

Quando estruturamos nossas investigações sobre a fluência em uma pequena sequência de movimentos, experimentamos fazê-la partindo do descontrole e deixando a gravidade agir no corpo (fluência livre), então indo até o controle máximo e incluindo a resistência contra a gravidade (fluência controlada). Observamos que a fluência livre é mais rápida e não tem tanta precisão no espaço, enquanto a fluência controlada parece mais lenta e com mais precisão no espaço, apresentando qualidades bastante distintas entre si.

Após nosso processo de investigação sobre o fator fluência, observamos que ele está presente em todos os movimentos que realizamos, pois se relaciona com o fluxo, com a energia que despendemos na execução do movimento, sendo um fator facilmente identificado no corpo. Esta característica o diferencia dos outros fatores, espaço, tempo e peso, que apresentam qualidades mais independentes que podem ser variadas e combinadas entre si. Como a fluência está presente em todos os movimentos, ela se relaciona diretamente com os impulsos internos, com o esforço que antecede todo o 
movimento físico e fornece as bases para que os outros fatores de movimento sejam desenvolvidos no corpo, nos gestos e ações.

\subsubsection{Laboratório de Criação: percepções de nossa experiência sobre os fatores de movimento}

Ao finalizar nossas investigações sobre os fatores de movimento, foi relevante constatar que, através da experiência de nossa práxis, percebemos e conscientizamos nossos corpos sobre cada um dos quatro fatores dentro de suas diferentes atitudes e qualidades: espaço direto e flexível, peso firme e suave, tempo súbito e sustentado, fluência controlada e livre. Após investigar cada fator, o corpo de cada atriz-bailarina foi imbuído dentro dos princípios de movimento presentes no Sistema Laban, tanto nos aspectos técnicos de cada fator quanto com relação a suas atitudes: atenção, intenção, decisão e progressão.

Segundo Laban (1978), trabalhar e desenvolver os fatores de movimento é importante para que o sujeito aprenda a se relacionar com a atenção (espaço), a intenção (peso) e a decisão (tempo), que são fundamentais para a nossa postura no mundo e constituem as bases de preparação de qualquer ação corporal.

\footnotetext{
Atenção, Intenção e Decisão são estágios de preparação interior de uma ação corporal externa. Esta se atualiza quando o esforço, através da fluência do movimento, encontra sua expressão concreta no corpo. (LABAN, 1978, p. 131)
}

Esta atualização do esforço em forma de expressão no corpo se realiza através dos fatores de movimento, principalmente do fator peso e de nossa relação com a gravidade. Segundo o texto do professor e pesquisador francês Hubert Godard (2002), toda a obra de Laban se baseia na "gestão do peso e os valores de expressividade, através dos fluxos e dos tratamentos do espaço e do tempo" (GODARD, 2002, p. 32). É a partir dessa relação entre peso e gravidade que criamos nossos movimentos, que atualizam o esforço no corpo através de gestos e ações singulares, particulares de cada corpo e pelas quais cada indivíduo vai configurando o que Laban denominou, segundo a historiadora Annie Suquet (2008), como assinatura corporal. De acordo com 
Suquet (2008), Laban faz do fator peso e da relação com a gravidade e a verticalidade o centro de seu pensamento sobre movimento:

De acordo com Laban, essa gestão complexa da verticalidade, e portanto, da relação à gravidade, depende de uma "atitude interior (consciente ou inconsciente)", que determina as qualidades dinâmicas do movimento. As modulações da transferência de peso definem, então, o ritmo dos movimentos, mas também o seu estilo. São elas, enfim, que conferem a cada indivíduo, desde a primeira infância, a sua "assinatura corporal", a configuração cinética de seus gestos. (SUQUET, 2008, p. 528)

Sendo assim, esta noção sobre a obra de Laban, desenvolvida tanto em Godard (2002) como por Suquet (2008), se tornou elementar em nossa pesquisa, já que nosso objetivo foi justamente encontrar no corpo de cada atriz-bailarina uma fisicalidade singular, uma assinatura corporal que permeasse toda a expressão gestual, física e cinestésica de cada intérprete.

Foi fundamental em nosso processo investigar os fatores de movimento, pois eles formam a base pela qual podemos configurar nossos movimentos e gestos na busca pela poética corporal particular de cada intérprete. Toda nossa práxis sobre as atitudes que compõem cada fator se tornaram fundamentais para todo nosso processo de investigação, que teve continuidade com o estudo sobre as ações básicas de esforço.

As atitudes presentes em cada fator, atenção, intenção, decisão e progressão, formam as bases pelas quais Laban estruturou e criou as ações básicas de esforço. Sendo assim, em nosso processo de investigação, ao familiarizar nossos corpos com os princípios de movimento presentes no Sistema Laban, nos preparamos para desenvolver a etapa seguinte de nossa pesquisa, o estudo sobre as ações básicas de esforço e experimentar essas ações em seus aspectos espaciais, rítmicos, dinâmicos e cinestésicos. Assim, demos continuidade à nossa investigação na elaboração de uma fisicalidade poética singular, em busca de nossa própria assinatura corporal.

\subsection{Laboratório de Criação: experiência sobre as oito ações básicas de esforço}

As ações básicas de esforço se concretizam a partir das combinações entre os fatores espaço, tempo e peso. A fluência não é considerada como 
fator determinante nessas ações porque, independentemente de qual seja a fluência do movimento, a ação acontece. Essas ações são elaboradas através da sensação do movimento, que, segundo Laban (1978), é essencial na experiência de situações expressivas.

\begin{abstract}
Enquanto que nas ações funcionais a sensação do movimento não passa de um fator secundário, nas situações expressivas, onde a experiência psicossomática é da maior importância, sua relevância cresce. Em tais situações, temos condições de observar mudanças de ênfase dentro dos fatores peso, espaço e tempo das ações corporais. Aparece também todo um conjunto de aspectos além dos de resistência, velocidade e direção, o qual se torna particularmente importante para as sensações dos movimentos. (LABAN, 1978, p. 121)
\end{abstract}

No que compreende a nossa experiência, a percepção sensorial e cinestésica do corpo e de nossos movimentos se tornaram fundamentais para a investigação sobre uma fisicalidade poética singular, pois foi através da percepção e da sensação que pudemos realizar nossas escolhas artísticas e estéticas.

O estudo sobre as oito ações básicas de esforço foi de grande relevância para nossas investigações, sendo elementar aqui esclarecer a noção de Laban (1978) sobre ação. Para ele, a ação se caracteriza por ser a representação externa do esforço, de uma atitude interna do sujeito que executa a ação, que pode ser tanto uma ação funcional quanto artística. A ação deve ser motivada pelo esforço interno e se concretiza através dos movimentos do corpo.

(...) as ações, em todo o tipo de atividade humana e, por conseguinte também da dança, consistem em sucessões de movimento onde o esforço definido do sujeito acentua cada uma delas. (LABAN, 1978, p. 140)

As oito ações básicas de esforço $(A B E)^{34}$ se encontram dentro do princípio da eukinética, pois se realizam através do esforço e de sua concretização por meio dos fatores de movimento. As $A B E$ acontecem quando estabelecemos uma postura definida perante os fatores (peso, espaço e tempo), bem como sobre as qualidades que compõem cada um deles. Portanto, as $\mathrm{ABE}$ são as combinações possíveis entre os fatores e suas qualidades de movimento, que relacionadas resultaram nas oito ações: pressionar, socar, torcer, pontuar, flutuar, chicotear, deslizar e sacudir. Segue

\footnotetext{
${ }^{34}$ Vamos utilizar na escrita deste capítulo a abreviação de ABE para nos referirmos às ações básicas de esforço, para facilitar o estudo.
} 
um quadro com as ações e seus fatores de movimento, que foi elaborada por nós a partir das referências estudadas em nossa pesquisa. ${ }^{35}$

Quadro 1 - Oito Ações Básicas de Esforço

\begin{tabular}{|c|c|c|c|}
\hline Ações Básicas & Peso & Tempo & Espaço \\
\hline Socar & firme & súbito & direto \\
\hline Pontuar & suave & súbito & direto \\
\hline Pressionar & firme & sustentado & direto \\
\hline Chicotear & firme & súbito & flexível \\
\hline Flutuar & suave & sustentado & flexível \\
\hline Torcer & firme & sustentado & flexível \\
\hline Sacudir & suave & súbito & flexível \\
\hline Deslizar & suave & sustentado & direto \\
\hline
\end{tabular}

Nossa investigação sobre as $A B E$ seguiu a mesma rotina $e$ metodologia $^{36}$ utilizada no estudo dos fatores de movimento. Em nossa exploração sobre as ações, foi importante conscientizar e perceber os fatores que compunham cada ação, bem como a sensação do movimento. Nosso corpo, ao se imbuir da sensação do movimento, acessava imagens que ilustravam as sensações de movimento que tínhamos ao trabalhar cada ação, contribuindo para a criação de sequências de movimento. Através da sensação, permitimos que o corpo fosse permeado por imagens que auxiliaram na elaboração de nossas ações. Segue um exemplo retirado do diário de campo desta pesquisa:

Trabalhamos sobre a Ação flutuar (sustentado, flexível, suave), dessa vez já incluímos a imagem no início do trabalho e isso colaborou muito na construção dessa Ação. Usamos a imagem de uma bolha de sabão que depois virou nosso próprio corpo e depois ainda a imagem de que em cada ponto do corpo existiam bolhas de sabão e nos movíamos a partir desses pontos, depois fizemos a sequência do Flutuar. A imagem ajudou muito no processo, acho que raciocinamos menos nos termos formais e mais na sensação da imagem e isso trouxe uma espécie de sensação para o corpo o que foi muito bom o corpo vestiu como eu uma máscara do Flutuar, acho que jogamos e

\footnotetext{
${ }^{35}$ Nossas referências de pesquisa sobre o Sistema Laban encontram-se no item 2.2 deste capítulo e também no item Referências Bibliográficas desta dissertação.

${ }^{36}$ Nossa metodologia e rotina de trabalho encontram-se expostas no item 2.3 deste capítulo.
} 
nos relacionamos com essa imagem e além dos movimentos o corpo se imbuiu de uma sensação que permeio os movimentos da sequência Flutuar. (Diário de campo de Kalisy Cabeda, segundo semestre de 2012) ${ }^{37}$

Notamos, assim, que quando os movimentos são permeados por imagens que auxiliam a acessar nossa sensação, o movimento acaba sendo a concretização de uma imagem que estava no plano da imaginação e que se concretiza visualmente através dos movimentos. O recurso da imaginação auxiliou no processo de trazer para as ações a sensação do movimento, que é fundamental no trabalho expressivo e poético do corpo. Desta forma, utilizar imagens presentes em nossas vivências e em nossa imaginação colabora para acessarmos a sensação da ação, bem como para a elaboração das sequências de movimento, pois através da sensação encontramos um apoio de sustentação para o movimento em seus aspectos dinâmicos e cinestésicos.

Outro aspecto relevante em nosso processo de estudo sobre as $A B E$ foi percebermos que as sequências criadas para cada ação continham alguns padrões de movimento que se repetiam, por exemplo: uma de nós utilizava movimentos mais circulares e saltos, enquanto a outra utilizava movimentos mais retos e ao nível do chão. Notamos, assim, que cada atriz-bailarina já carrega consigo alguns padrões de movimentos, gestos característicos da fisicalidade de cada intérprete e que se tornaram presentes ao longo de nossa práxis. Contudo, alterar esses padrões de movimentação é importante também para ampliar nosso vocabulário corporal, pois cada atriz-bailarina produzia uma qualidade especifica de movimento.

No processo de transmissão das sequências de movimentos criadas a partir de cada Ação, percebemos que, ao transmitir e apreender as sequências, ampliamos nossas possibilidades corporais, pois acessamos novas qualidades físicas e expressivas em cada Ação. Nesse processo de transmissão e aprendizagem, abrimos nossa percepção e sensibilidade para entender e receber em nossos corpos a sensação do outro sobre a forma de realizar cada uma das Ações.

\footnotetext{
${ }^{37}$ Diário de campo do trabalho prático (24/10/12).
} 
Essa experiência de aprender cada sequência individual e posteriormente executá-las em dupla nos trouxe uma percepção de composição, de criação coreográfica. Apesar de não termos como objetivo prévio o estabelecimento de uma coreografia, percebemos que a relação entre os corpos por si só já traz consigo um discurso que se inscreve através do tempo, do espaço e dos corpos, que carregam em si experiências, metáforas e relações que existem independentemente da nossa vontade, já intrínsecas na própria relação de homem para homem, da própria vida em si. Segundo o pesquisador Dubray (1997), o corpo é biografia:

Em seu invólucro carnal, o corpo é dotado de uma morfologia, de um
peso, de uma plasticidade, de uma mobilidade, de um volume.
Matéria e forma, o corpo é, aqui, físico. Enquanto ser vivente, ele
possui também uma natureza própria, nascimento, envelhecimento. O
corpo é, então uma energia, um fluxo um principio de vitalidade.
Finalmente face exposta de um mundo interior, ele se faz sensação
do tempo que o habita, torna sua carne seu princípio identificador de
uma memória, estigma de um corpo vivo (vivido). O corpo é aqui
biografia. (DUBRAY, 1997, p. 19)

Esse processo de execução das sequências em dupla propiciou o surgimento de uma possível composição coreográfica baseada na relação física e espacial de cada intérprete e no material físico e expressivo individual. Ambos podem ser modificados e intensificados a partir da relação com a nossa própria fisicalidade e com esse material dentro de uma composição cênica. Contudo, estas percepções e relações se concretizaram posteriormente em nossa práxis com a elaboração do exercício cênico de composição, que compreendeu a última etapa de nossa pesquisa e se encontra no capítulo quatro desta dissertação.

Sendo assim, ao final de nosso estudo sobre as oito ações básicas de esforço, socar, pressionar, torcer, chicotear, flutuar, deslizar, pontuar e sacudir, elaboramos uma sequência de movimentos para cada Ação, o que resultou em um total de dezesseis sequências de movimentos. No DVD em anexo a esta dissertação encontram-se as fotografias de cada uma das dezesseis sequências de movimentos das $A B E$. Seguem algumas fotografias das sequências de movimentos. 
Figura 9 - Atriz-bailarina Sissi Betina Vennturin realizando a sequência de movimentos da ABE torcer.

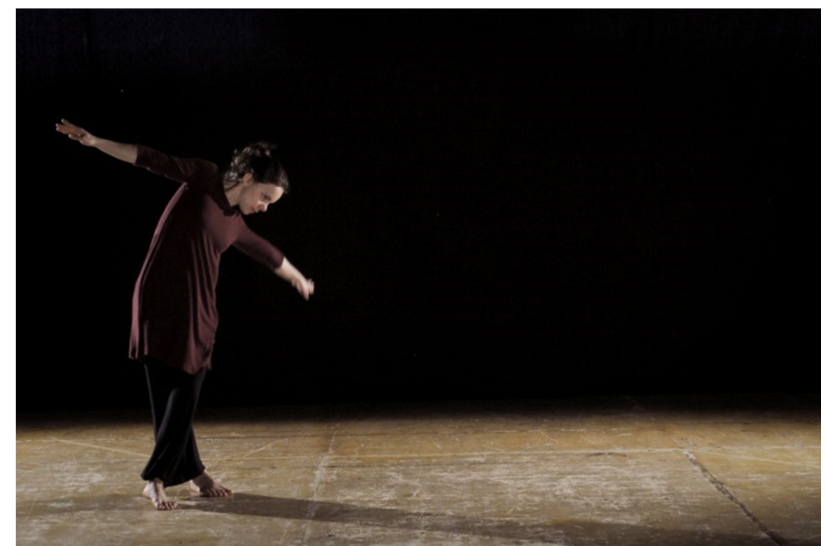

Fonte: Foto Di Pannacci.

Figura 10 - Atriz-bailarina Sissi Betina Vennturin realizando a sequência de movimentos da ABE flutuar.



Fonte: Foto Di Pannacci.

Figura 11 - Atriz-bailarina Kalisy Cabeda realizando a sequência de movimentos da ABE torcer.

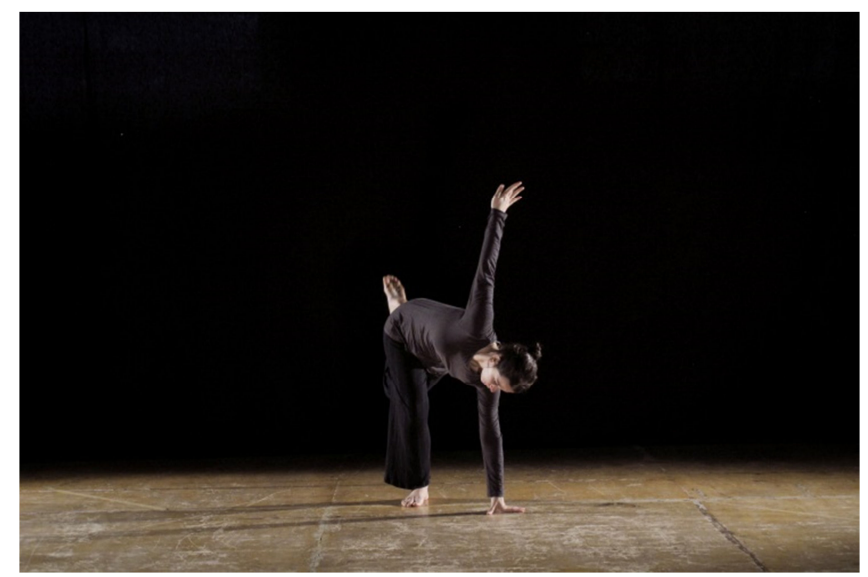

Fonte: Foto Di Pannacci. 
Figura 12 - Atriz-bailarina Kalisy Cabeda realizando a sequência de movimentos da ABE pressionar.

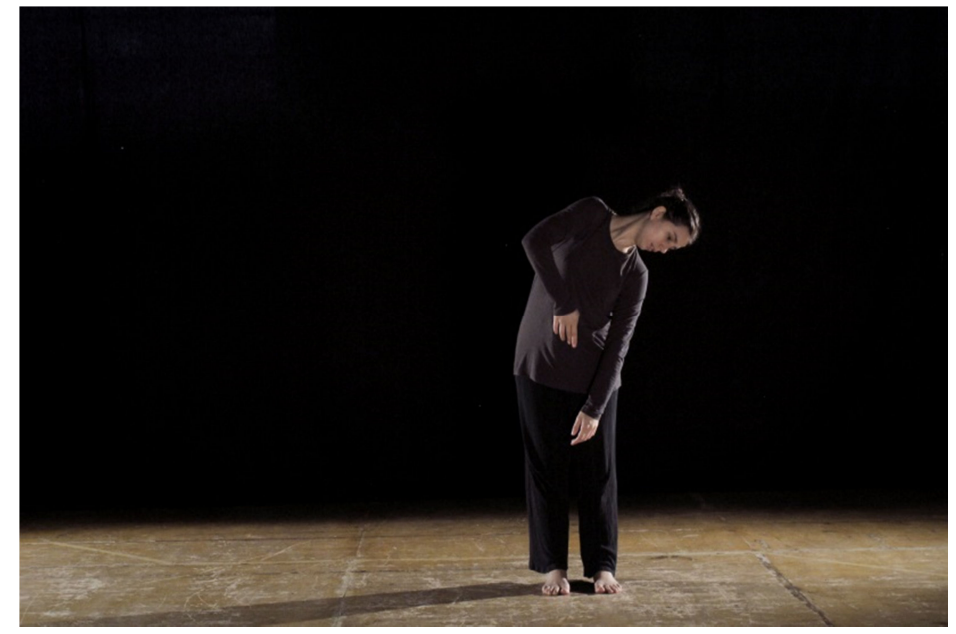

Fonte: Foto Di Pannacci.

\subsubsection{Laboratório de Criação: investigação sobre as seis ações incompletas}

Em nossa investigação sobre as ações dentro da eukinética do Sistema de Laban, estudamos também as seis ações incompletas (Al), ${ }^{38}$ que, segundo Laban são:

Ações Incompletas são quando apenas dois fatores de movimento conferem forma ao movimento, os esforços incompletos fazem parte do movimento expressivo, quer sejam conscientes ou inconscientes. (LABAN, 1978, p. 127)

As ações incompletas acontecem quando combinamos dois dos quatro fatores de movimento (peso, espaço, tempo e fluência) e, consequentemente, suas qualidades. Segundo Laban (1978), de acordo com sua observação sobre as ações funcionais e as ações de treinamento artístico, este tipo de ação incompleta ocorre em movimentos de transição e preparação entre uma e outra ação básica de esforço. As seis Al são: acordado (consciente certo ou incerto); onírico (inconsciente difuso); remoto (foco, atenção); perto (presença de impacto caloroso ou de cuidadosa consideração); estável (teimosa ou receptiva) e móvel (pode ser fácil ou tenaz). Segue um quadro com as seis

\footnotetext{
${ }^{38}$ Vamos utilizar na escrita deste capítulo a abreviação Al para nos referirmos ás ações incompletas, para facilitar o estudo.
} 
ações incompletas e seus fatores de movimento, elaborada por nós a partir das referências estudadas em nossa pesquisa. ${ }^{39}$

Quadro 2 - Seis ações incompletas

\begin{tabular}{|c|c|}
\hline Esforço Incompleto Atitude & Fatores de Movimento \\
\hline Acordado (onde e quando) & Espaço e Tempo \\
\hline Onírico (como e o quê) & Fluência e Peso \\
\hline Remoto (onde e como) & Espaço e Fluência \\
\hline Perto (o quê e quando) & Peso e Tempo \\
\hline Estável (onde e o quê) & Espaço e Peso \\
\hline Móvel (quando e como) & Tempo e Fluência \\
\hline
\end{tabular}

Nossa investigação sobre as ações incompletas seguiu a mesma rotina e metodologia ${ }^{40}$ utilizada no estudo sobre os fatores de movimento e sobre as ações básicas de esforço. Nesse processo, continuamos utilizando a imaginação como estímulo para acessar a sensação dos movimentos e assim elaborar as sequências individuais de cada ação.

Percebemos que, na etapa de transmissão e aprendizagem das sequências de movimentos de cada AI, foi fundamental conscientizar e precisar os fatores que compunham cada Ação, bem como suas qualidades e as sensações dos movimentos, que estavam permeadas pelas imagens pessoais elaboradas por cada atriz-bailarina. Isso colaborou tanto para a estruturação das sequências como para sua apropriação e transmissão.

Ao final desse estudo, cada intérprete criou uma sequência de movimentos para cada uma das ações incompletas, acordado, onírico, remoto, perto, estável e móvel, totalizando doze sequências. No DVD em anexo a esta dissertação encontram-se as fotografias de cada uma delas. Seguem algumas fotografias das sequências de movimento.

\footnotetext{
${ }^{39}$ Nossas referências de pesquisa sobre o Sistema Laban encontram-se no item 2.2 deste capítulo e também no item Referências Bibliográficas desta dissertação.

${ }^{40}$ Nossa metodologia e rotina de trabalho encontram-se expostas no item 2.3 deste capítulo.
} 
Figura 13 - Atriz-bailarina Sissi Betina Vennturin realizando a sequência de movimentos da Al Onírico.

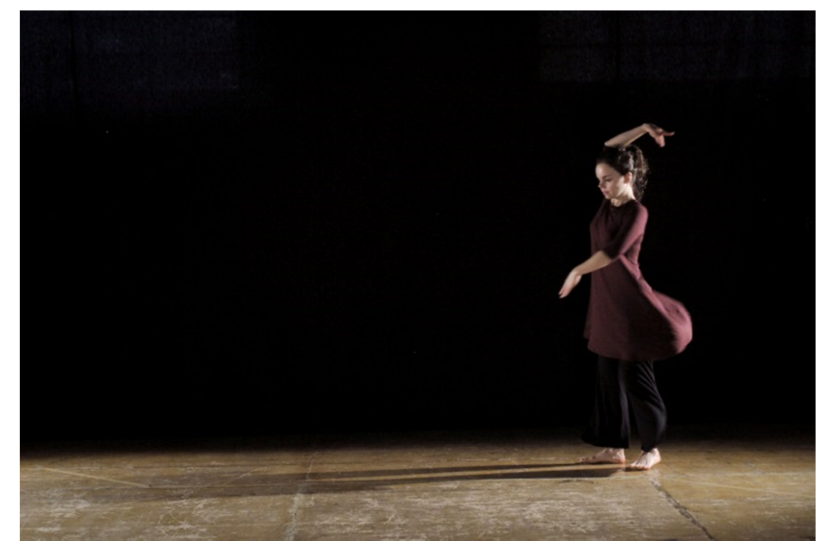

Fonte: Foto Di Pannacci.

Figura 14 - Atriz-bailarina Sissi Betina Vennturin realizando a sequência de movimentos da Al Móvel.



Fonte: Foto Di Pannacci.

Figura 15 - Atriz-bailarina Kalisy Cabeda realizando a sequência de movimentos da AI Perto.

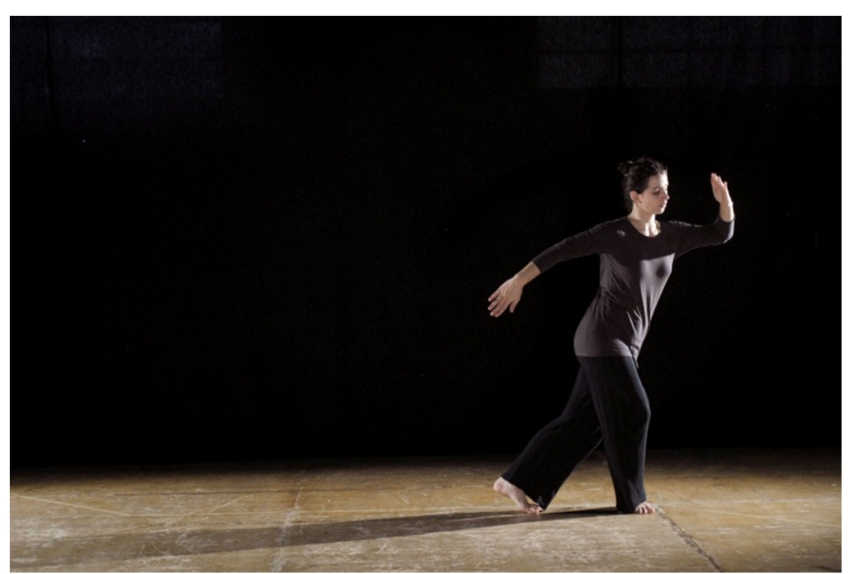

Fonte: Foto Di Pannacci. 
Figura 16 - Atriz-bailarina Kalisy Cabeda realizando a sequência de movimentos da Al Estável.

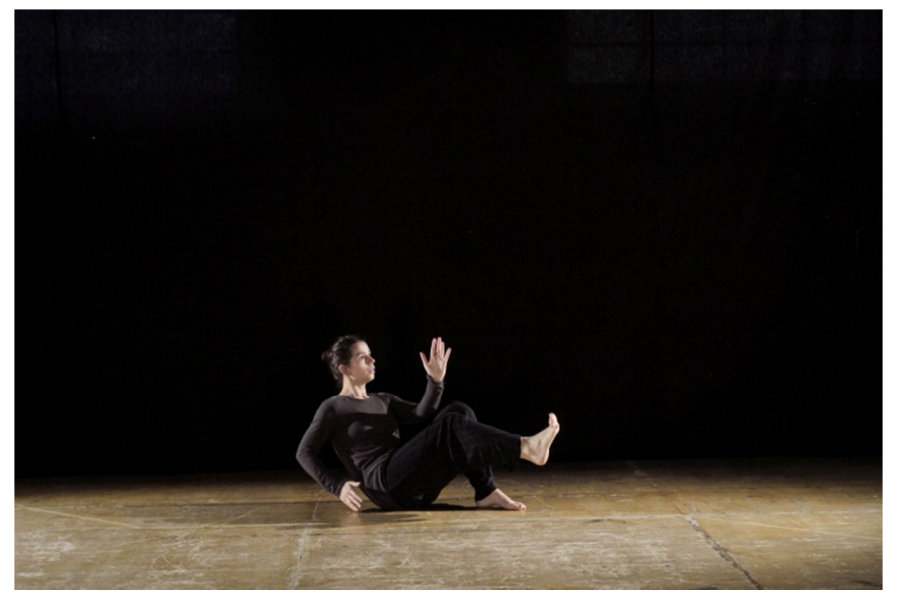

Fonte: Foto Di Pannacci.

\subsubsection{Laboratório de Criação: investigação sobre os três ímpetos de ação}

Em nosso recorte de pesquisa sobre as ações dentro da eukinética do Sistema de Laban, realizamos o estudo sobre o último elemento, os ímpetos de ação (IA).$^{41}$ Os ímpetos de ação são combinações entre três fatores de movimento. Se nas ações básicas de esforço a fluência não é considerada um fator determinante e os fatores que constituem cada ação são peso, tempo e espaço, quando um desses fatores é substituído pelo fator fluência, temos o que Laban denomina de ímpeto de ação. São eles: ímpeto de visão (não há uma atitude ativa em relação ao peso), ímpeto de encanto (não há uma atitude ativa em relação ao tempo) e o ímpeto de paixão (não há uma atitude ativa em relação ao espaço). Segue um quadro com os três ímpetos de ação e seus fatores de movimento, elaborada por nós a partir das referências estudadas em nossa pesquisa. ${ }^{42}$

Quadro 3 - Três ímpetos de ação

\begin{tabular}{|c|c|}
\hline Ímpeto de Ação & Fatores do Movimento \\
\hline Ímpeto de Visão & Espaço, Fluência e Tempo. \\
\hline Ímpeto de Encanto & Peso, Espaço e Fluência. \\
\hline Ímpeto de Paixão & Peso, Fluência e Tempo. \\
\hline
\end{tabular}

\footnotetext{
${ }^{41}$ Vamos utilizar na escrita deste capítulo a abreviação de IA para nos referirmos aos ímpetos de ação para facilitar o estudo. ${ }^{42}$ Nossas referências de pesquisa sobre o Sistema Laban encontram-se no item 2.2 deste capítulo e
também no item Referências Bibliográficas desta dissertação.
} 
Nossa investigação sobre os ímpetos de ação seguiu a mesma rotina e metodologia ${ }^{43}$ utilizada no estudo sobre os fatores de movimento e sobre as ações básicas de esforço. Como estas foram as últimas ações que pesquisamos, percebemos que nossos corpos já estavam mais adaptados com os princípios da eukinética referentes ao Sistema Laban e isso contribuiu para a elaboração de nossas sequências de movimento, as quais seguimos criando com base nos fatores que compunham cada IA e suas qualidades, bem como sobre as sensações dos movimentos.

O estudo sobre os ímpetos de ação visão, encanto e paixão resultou em seis sequências de movimentos. Ao final de nossa investigação sobre as ações do Sistema Laban, havíamos elaborado um total de trinta quatro sequências de movimentos, resultado das dezesseis elaboradas nas ações básicas de esforço, das doze nas ações incompletas e seis nos ímpetos de ação. No DVD em anexo a esta dissertação encontram-se as fotografias de todas as sequências criadas nesta investigação. Seguem algumas fotografias das sequências de movimento dos ímpetos de ação.

Figura 17 - Atriz-bailarina Sissi Betina Vennturin realizando a sequência de movimentos do IA Paixão.

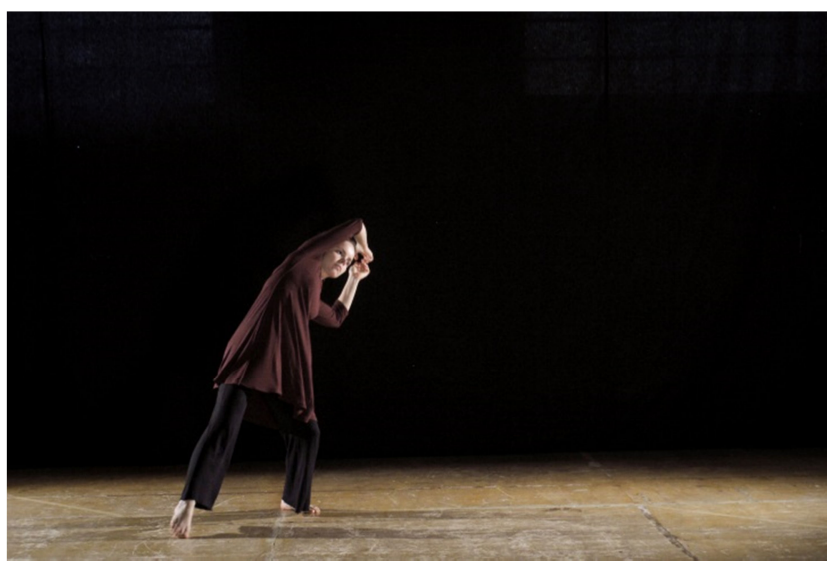

Fonte: Foto Di Pannacci.

\footnotetext{
${ }^{43}$ Nossa metodologia e rotina de trabalho encontram-se expostas no item 2.3 deste capítulo.
} 
Figura 18 - Atriz-bailarina Sissi Betina Vennturin realizando a sequência de movimentos do IA Visão.

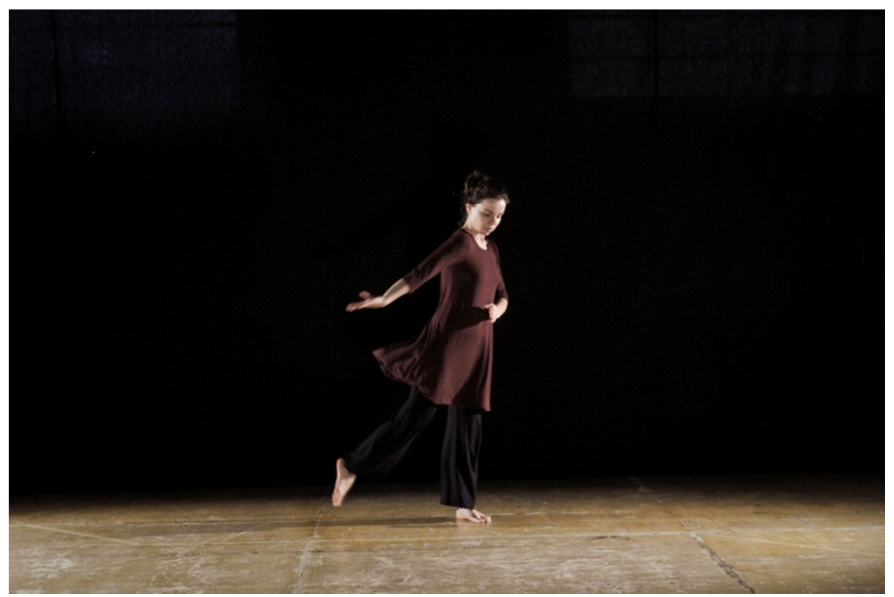

Fonte: Foto Di Pannacci.

Figura 19 - Atriz-bailarina Kalisy Cabeda realizando a sequência de movimentos do IA Encanto.

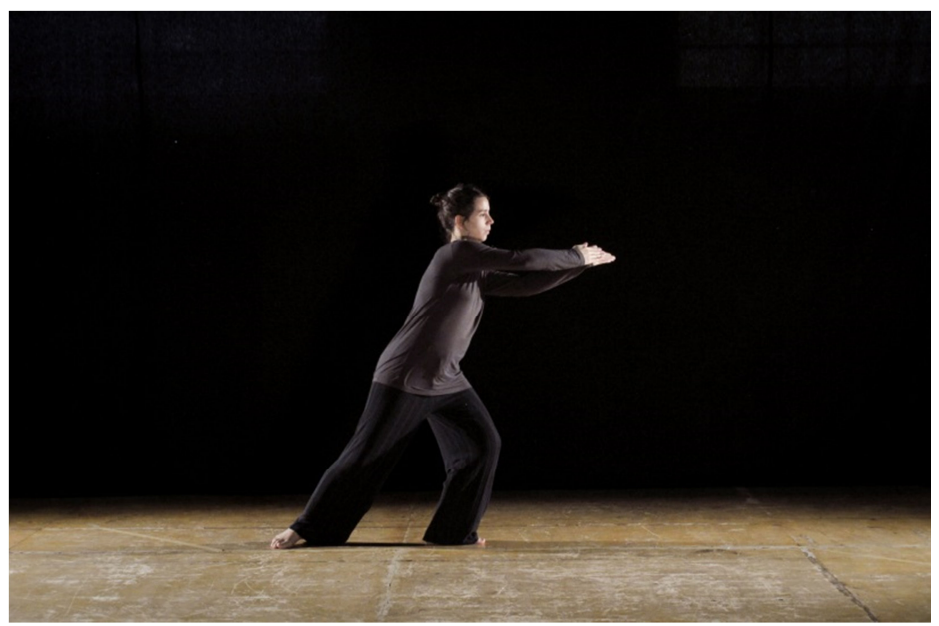

Fonte: Foto Di Pannacci.

Figura 20 - Atriz-bailarina Kalisy Cabeda realizando a sequência de movimentos do IA Visão.

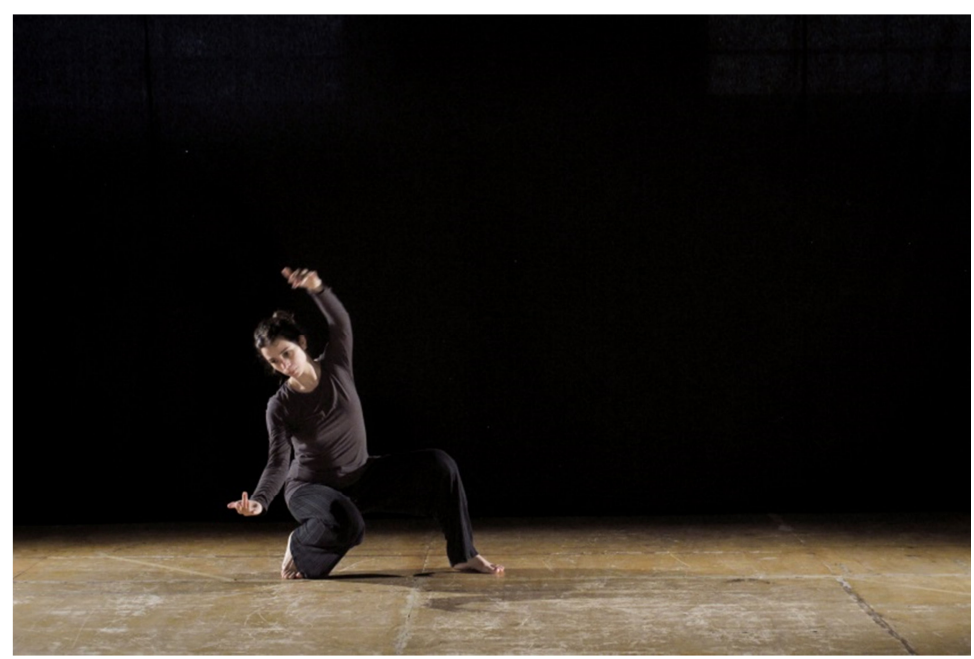

Fonte: Foto Di Pannacci. 


\subsection{Laboratório de Criação: percepções finais de nossa experiência sobre os princípios de movimentos do Sistema de Rudolf von Laban}

Ao finalizar nosso processo de investigação sobre os princípios do Sistema de Laban, alguns aspectos se mostraram importantes e os destacamos como pontos relevantes de nossa percepção acerca do processo investigativo/criativo:

- Em nossa práxis sobre os fatores de movimento, desenvolver e conscientizar cada um dos fatores foi de fundamental importância para todo nosso percurso de investigação, pois foi através da sensibilização dos fatores e suas qualidades que elaboramos o material palpável para a criação física, expressiva e cinestésica do corpo.

- Estudar todos os quatro fatores foi fundamental para nosso processo. Destacamos dois fatores que se tornaram muito relevantes em nosso percurso: o espaço e o peso. Ao estudar o fator espaço, ativamos a consciência dos planos (mesa, roda, porta), dos níveis (baixo, médio e alto) e da cinesfera como possibilidades de mover o espaço, assim nossos movimentos ampliaram suas qualidades de volume e densidade. Além disso, esses recursos podem ser utilizados como imagens que auxiliam em nossa percepção física e espacial, assim podemos imaginar o espaço de acordo com os níveis, os planos ou a cinesfera. Através dessas imagens sobre o espaço que circunda o corpo, colocamos uma intenção no movimento que reverbera no corpo e, consequentemente, no espaço que cada movimento ocupa.

- No estudo sobre o fator peso, destacamos nossa investigação sobre a gravidade e a verticalidade, que foram de grande relevância em nosso percurso de investigação. Através da relação entre o peso e a gravidade, pudemos descobrir movimentos e gestos que são particulares de cada atriz-bailarina e que fazem partem do registro corporal que define a fisicalidade singular de cada uma. Como já mencionamos e refletimos no tópico 2.4.4 deste capítulo, segundo a historiadora Annie Suquet (2008), Laban faz do fator peso e de sua ligação com a gravidade e a verticalidade 
o centro de seu pensamento sobre movimento. É a partir dessa relação que o ator-bailarino desenvolve sua assinatura corporal.

- Nossa investigação sobre ações básicas de esforço que resultaram nas trinta e quatro sequências de movimento se constituiu em um estudo prático do corpo dentro dos princípios de movimento do Sistema Laban. Assim, percebemos que foi fundamental nossa prévia conscientização e sensibilização sobre os princípios dos quatro os fatores tempo, espaço, peso e fluência, pois estes formaram as bases sólidas que guiaram nossos corpos na exploração, improvisação e criação das sequências de movimento.

- No processo de criação das sequências de movimento, além da experiência prévia sobre os princípios dos fatores de movimento, foi fundamental perceber a sensação do movimento, pois através dela nosso corpo acessou imagens vindas da vivência e da imaginação pessoal de cada atriz-bailarina e elas preencheram nossos movimentos de qualidades cinestésicas e expressivas. Através dos fatores de movimento e da sensação do movimento, aliados à nossa imaginação, conseguimos atualizar nossos impulsos internos, ou melhor, nosso esforço em ações e gestos concretos no tempo e no espaço. Por meio desses gestos e ações, elaboramos sequências de movimento com uma lógica física e cinestésica fundamentadas na sinceridade de nossas sensações, que se concretizaram através de nossas sequências de movimentos. Essa atualização do esforço em movimentos visíveis no corpo é de extrema importância para o desenvolvimento de um corpo expressivo, ${ }^{44}$ que encontra na fisicalidade de cada atriz-bailarina sua poesia.

- Todo o processo de criação das sequências de movimento das ações básicas de esforço foi registrado através de uma câmera fotográfica e este registro foi de extrema importância para a observação de nossa pesquisa e elaboração das sequências. Ao assistirmos os vídeos, percebemos nosso desenvolvimento físico e expressivo ao longo dos estudos sobre os fatores de movimento e as ações. Além disso, assistir

\footnotetext{
${ }^{44}$ Aqui estamos entendo o corpo expressivo segundo a definição de Cohen: "Um corpo que se expressa sob a égide da poiesis (enquanto produção e presentação) mais do que da mimesis (da ordem da imitação e representação)" (COHEN, 1998, p. 43).
} 
aos vídeos foi importante, pois permitiu uma observação externa, um olhar de espectador sobre o material produzido. Esta observação crítica sobre o trabalho complementou nossa percepção e colaborou para nosso progresso na execução das sequências de movimentos.

- No que diz respeito à nossa experiência sobre a transmissão e aprendizagem das sequências de movimentos, observamos que esse processo foi muito rico, pois a partir dele ampliamos nossas possibilidades corporais e expressivas. Através da percepção e concretização cinética do movimento que outra pessoa criou e que ganhou forma em nossos corpos, enriquecemos nosso vocabulário corporal e ampliamos nosso entendimento sobre diferentes lógicas de criação corporal.

- Percebemos que, ao recordar o movimento e transmiti-lo ao outro, utilizamos o recurso da sensação do movimento e das imagens que criamos a partir da sensação corporal na elaboração das sequências de movimento individuais. A utilização de nosso corpo, aliado à imaginação, ativou nossas sensações corporais, o que permitiu que no momento da transmissão das sequências esse recurso fosse utilizado para guiar nossa aprendizagem dos movimentos. Percebemos assim que a sensação se relaciona com a lógica cinética do movimento, que pode ser preenchida pelo imaginário poético de cada atriz/bailarina.

- Além disso, o trabalho de aprender e transmitir cada sequência de movimentos foi um treino que exercitou nossa capacidade de recordar as qualidades cinéticas e expressivas do movimento. A partir da prática de recordar e repetir, vamos exercitando a nossa memória, que aciona com mais habilidade e facilidade as sequências de movimentos. Sobre a importância de aprender e observar os movimentos de outra pessoa, encontramos em uma citação de Laban (1978) uma bela reflexão:

Toda pessoa tem a tendência de ampliar a gama de suas capacidades de esforço, sendo que essa ampliação se relaciona ao seu próprio desenvolvimento pessoal. (...) A observação de esforço, quando a serviço de uma caracterização, tem uma penetração nas atitudes interiores do homem que é realizada segundo um ângulo diferente daquele empregado quando se trata da investigação de períodos estilísticos. Ao estudar uma pessoa, o artista logo se 
apercebe de que os movimentos observados variam quanto a sua significância e à sua importância. (LABAN, 1978, p. 166)

Para finalizar este capítulo, gostaríamos de enfatizar que todo nosso processo de investigação sobre os princípios de movimento do Sistema de Laban foi fundamentado na improvisação. Por meio dela exploramos e elaboramos nossa experiência tanto sobre os fatores de movimento como sobre as ações básicas de esforço. Assim, se torna relevante trazer novamente a noção de improvisação que se encontra no tópico 2.3 deste capítulo e que se refere à nossa metodologia de pesquisa.

Em nossos estudos, utilizamos a noção de improvisação segundo a professora e pesquisadora Launay (1999). Para a autora, a improvisação em Laban acontece por meio de uma experiência de dança que se dá entre o esquecer e o rememorar no corpo e em seus fluxos de movimento.

Foi a partir desse esquecer e rememorar, dessa experiência de movimento que dá acesso a uma mobilidade íntima fruto da vivência singular de cada atriz-bailarina, que nos permitimos acessar nossos fluxos de sensação, de imaginação e de percepção, que se atualizam através de nossos movimentos, gestos e ações. Segundo Suquet (2008), Laban, em suas improvisações, desenvolve no ator-bailarino um estado de receptividade para os fluxos sensoriais do corpo:

Assim como o arqueiro zen ou o ator do teatro nô, o improvisador segundo Laban desenvolve um estado de "presença-ausência" que o torna permeável a fluxos sensoriais sutis, aos quais reage com todo o seu ser e instantaneamente. Levada a suas consequências últimas, a improvisação abre a porta para uma perturbação proprioceptiva, uma embriaguez cinestésica onde se perdem as referências, reavivando disposições motrizes adormecidas. (SUQUET, 2008, p. 526)

É por meio dessa receptividade, desse estado de embriaguez cinestésica, que nosso corpo é permeado por estímulos sensoriais pelos quais acessamos nossos sentidos, que encontram no corpo uma experiência de movimento; segundo Launay (1999), um saber-sentir.

Esquecer o estado presente do corpo a fim de acolher os estímulos plurais da sua memória involuntária é, precisamente, adquirir uma experiência de movimento, um saber-sentir que não se mede a não ser pela eficácia de nossos sentidos. (LAUNAY, 1999, p. 80) 
É nessa experiência de saber-sentir que podemos atualizar em gestos, ações e movimentos nossos fluxos internos, nosso esforço que se concretiza por meio dos fatores de movimento e da sensação. Dessa forma, vamos identificando e configurando uma fisicalidade singular, a assinatura corporal de cada atrizbailarina. Partindo dessa fisicalidade, vamos elaborando uma corporeidade particular para coreografar o que Laban denomina como poema do esforço:

O dançarino não experimenta somente o esqueleto articulado, "sistema complexo de gruas e alavancas de extensões variáveis" (Laban, 1975: 92), mas também a massa e o volume. Construir sua corporeidade, coreografar "um poema do esforço" (Laban 1959), implica na consciência de uma norma não normativa, do "regime" próprio de cada dança (...). Isso supõe uma consciência do centro de gravidade do movimento, o saber-sentir das circulações do sangue e do ar, e uma condução do esforço, isto é, das ínfimas modificações na mudança do peso que determinam o ritmo e cuja percepção varia de acordo com o estado do dançarino. (LAUNAY, 1999, p. 83)

Sendo assim, ao finalizar nossa investigação sobre os fatores de movimento e as ações básicas de esforço do Sistema de Laban, desenvolvemos habilidades técnico-artísticas que despertaram nossa percepção, sensibilidade e intuição para elaborarmos uma corporeidade na qual os movimentos e os gestos são guiados pela consequência cinética e pelas sensações físicas presentes na experiência corporal de cada atriz-bailarina.

Contudo, sabemos que este foi um percurso ainda curto, pois para desenvolvermos uma fisicalidade que possa ser a base para a elaboração de linguagens poéticas, de um poema do esforço, muito é preciso estudar, investigar e realizar. Porém, nossos resultados nos conduziram a um material de estudo interessante que nos permitiu refletir sobre nossa experiência a partir de nossos corpos, para assim desenvolvermos um pensamento com base em nossas próprias vivências, um pensamento do/no corpo (COSTAS, 2010, p. 35).

Dessa forma, seguimos nossas investigações na elaboração de um conhecimento fundamentado em nossas experiências e, no próximo capítulo desta dissertação, refletimos sobre o processo de estudo de nossos corpos dentro da pedagogia de Jacques Lecoq. 


\section{CAPÍTULO 3 - LABORATÓRIO DE CRIAÇÃO: DESENVOLVENDO O CORPO CÊNICO A PARTIR DE PRINCÍPIOS DA PEDAGOGIA DE JACQUES LECOQ}

Seguimos nossas investigações na elaboração de um conhecimento e uma reflexão a partir de nossa práxis, que neste capítulo se refere a alguns princípios da pedagogia de Jacques Lecoq. Então, iniciamos esclarecendo o campo de nossa experiência, a qual nos possibilitou escolher e desenvolver nossas investigações sobre a metodologia das transferências de Lecoq. Assim, neste capítulo se faz necessário novamente esclarecer um pouco sobre nossa vivência pessoal dentro desta metodologia, já que a nossa pesquisa se fundamentou na experiência para a elaboração de conhecimento.

Sendo assim, apresentamos as referências sobre a pedagogia de Lecoq que nos permitiram intuir os caminhos traçados nesta pesquisa. Nesse sentido, é preciso relatar um pouco sobre a experiência pessoal da pesquisadora que vos fala no que se refere à metodologia das transferências. Como já mencionamos no primeiro capítulo, entre os anos de 2006 e 2010, frequentei o curso de Teatro Bacharelado na Universidade Federal do Rio Grande do Sul. Nesse período, aprofundei minha formação em teatro e vivenciei diferentes aulas, desde história do teatro até aulas de improvisação, expressão corporal, composição cênica e criação de exercícios cênicos. Durante esse percurso, tive a oportunidade de conhecer e estudar com diferentes professores, que lecionavam a partir de distintas referências, conceitos, métodos e pedagogias.

Ao longo da minha graduação, tive a oportunidade de frequentar as aulas e o grupo de pesquisa da Profa. Dra. Inês Alcaraz Marocco. ${ }^{45}$ A pedagogia de Jacques Lecoq se encontrava entre as abordagens que ela utilizava, já que

\footnotetext{
45 Inês Alcaraz Marocco Possui graduação em Bacharelado em Direção Teatral e Licenciatura em Arte Dramática pela Universidade Federal do Rio Grande do Sul (1975), mestrado em Diplôme d'Études Aprofondies - Université de Paris VIII (1985) e doutorado em Doctorat en Esthétique Sciences et Technologie des Arts - Université de Paris VIII (1997). Possui a formação na École Internationale de Théâtre, Mime et Mouvement Jacques Lecoq (1983/1984) e L.E.M - Laboratoire d’Études du Mouvement (1993/94). Atualmente é Profa. Dra. Associado III da Universidade Federal do Rio Grande do Sul. Tem experiência na área de Artes, com ênfase em Direção Teatral, atuando principalmente nos seguintes temas: arte do ator, etnocenologia, antropologia teatral, sistema de treinamento e cultura gaúcha. Fonte: http://buscatextual.cnpq.br/buscatextual/visualizacv.do?id=E2409 Acesso em 05 de junho de 2014.
} 
havia realizado a formação na Escola de Lecoq, ${ }^{46}$ na França. Entre as diferentes metodologias que ela utilizava, estavam o trabalho com máscara (tanto da commedia dell'arte, como com máscara neutra), o jogo teatral, a improvisação ${ }^{47}$ e a metodologia das transferências. Todas foram muito importantes na minha formação enquanto graduanda de Teatro. Contudo, a metodologia das transferências, método pelo qual o intérprete transpõe para o corpo elementos da natureza, foi uma experiência muito rica. Através dessa metodologia, que se encontra detalhada ao longo deste capítulo, éramos convidados a embarcar na imaginação e no corpo para acessar nossas sensações sobre os quatro elementos da natureza: terra, fogo, ar e água. Nesse processo, realizado a partir da sensação corporal e da imaginação sobre cada elemento, pude vivenciar uma experiência na qual o corpo e as imagens sobre cada elemento eram os guias que me conduziram a muitas sensações novas sobre meu corpo e suas possibilidades de criação poética. Estas criações não vinham de um texto dramático ou de um personagem de uma peça, mas sim da minha imaginação, que preenchia o corpo de sensações que possuíam uma lógica própria concretizada nos movimentos do corpo. Essa lógica era fundamentada na experiência dinâmica e cinestésica do corpo e não em uma história ou em um enredo com início, meio e fim, uma lógica de movimento e de criação desenvolvida e articulada por mim dentro de minha experiência sobre cada elemento e que poderia ser articulada como uma linguagem cênica, pois era outra maneira de criar e desenvolver enredos, situações dramáticas e até personagens. Sabemos que existem muitas abordagens que possibilitam esse tipo de experiência, principalmente no teatro contemporâneo. Porém, para mim, naquele momento, foi uma descoberta muito valiosa que ampliou minha percepção sobre o corpo, a imaginação e a criação cênica, e que desde então acompanha minhas escolhas artísticas estéticas.

Após esse breve relato sobre minha experiência pessoal, acreditamos esclarecer um pouco as razões que nos conduziram a realizar o recorte de nossa metodologia de trabalho a partir do estudo e práxis sobre a metodologia

\footnotetext{
${ }^{46}$ Lecoq fundou sua Escola em Paris em 1956, a École Internationale de Théatre Jacques Lecoq, que continua formando estudantes até os dias atuais.

${ }^{47}$ Todas essas terminologias encontram-se detalhadas ao longo desse capítulo, no tópico 3.2 .
} 
das transferências de Lecoq. Nesse sentido, acreditamos relevante salientar que, na investigação sobre o corpo cênico à qual nos propomos, os princípios de movimento desenvolvidos a partir da prática sobre a pedagogia de Lecoq são muito amplos e podem compreender distintas abordagens. Em nosso caso, percebemos que se trata de um dispositivo muito eficiente na elaboração de gestos e movimentos fundamentados nas sensações e na imaginação do atorbailarino, podendo ser utilizado tanto no teatro como na dança, pois esta metodologia convida o intérprete a encontrar novas lógicas de criação corporal para a cena, acessando assim uma atuação baseada em seus movimentos e gestos. Nesse sentido, essa metodologia pode ser um veículo de criação muito potente no intercâmbio entre o teatro e a dança, bem como na elaboração de uma fisicalidade poética presente no corpo de cada ator-bailarino.

Desse modo, neste terceiro capítulo abordamos alguns elementos referentes à metodologia das transferências de Lecoq que se tornaram presentes na práxis de nosso percurso investigativo/criativo. Esses aspectos são abordados através de uma pequena contextualização sobre a pedagogia de Jacques Lecoq, bem como sobre a metodologia das transferências e sua utilização dentro da experiência em nossos Laboratórios de Criação, para assim refletirmos sobre a pedagogia de Lecoq na elaboração de um conhecimento do/no corpo (COSTAS, 2010, p. 35) através da práxis de nossa experiência.

\subsection{Jacques Lecoq: um teatro do corpo e do movimento}

Jacques Lecoq nasceu em 15 de dezembro de 1921 e faleceu em 19 de janeiro de 1999, em Paris. Ao longo de toda a sua vida, foi fascinado pelo movimento do corpo, o gesto, o teatro e a imaginação. Ele se encontra dentro dos grandes nomes do teatro do século XX e buscou estabelecer um teatro fundamentado no corpo do ator, seus movimentos, suas ações e sua imaginação.

Como mencionado no capítulo um desta dissertação, todo o século $X X$ foi marcado por artistas, encenadores e pesquisadores que trouxeram o corpo do ator para o centro das suas criações e composições cênicas. Muitos foram os que desenvolveram seus métodos e suas pedagogias para realizar uma preparação física do ator, um treinamento para desenvolver suas habilidades 
técnico-artísticas, e Lecoq não se diferenciava deles. Segundo o pesquisador Simon Murray (2003), em seu livro sobre Jacques Lecoq:

Ao menos em um aspecto, Lecoq não difere de outros inovadores chave no treinamento de atores - por exemplo, Stanislavsky, Meyerhold, Copeau, Brecht, Decroux e Grotowski. O que todas essas figuras compartilham são campos mais amplos de interesse intelectual, que se estende muito além das habilidades 'técnicas'. É impossível entender os diferentes modelos de treinamento de atores sem considerar o tipo de teatro ou performance para os quais essas pedagogias foram destinados em sua concepção. Nenhum desses homens procurou simplesmente equipar jovens atores para o status quo teatral. De formas frequentemente extremamente contrastantes, cada um deles estava tentando transformar e redefinir os parâmetros e possibilidades do que constituía o teatro e qual seu propósito deveria ser. (MURRAY, 2003, p. 26) ${ }^{48}$

No desenvolvimento de seu teatro e de sua pedagogia, fundamentados no movimento e nos gestos do ator, Lecoq recorreu a diferentes referências e influências, porém duas delas foram muito importantes: Antonin Artaud ${ }^{49}$ (18961948) e Jacques Copeau ${ }^{50}$ (1879-1949). O primeiro, no que se refere à visualidade e à intensidade da cena proposta pelo seu teatro, e o segundo pelo movimento e pela ação do ator como as molas propulsoras para a criação. Assim, Lecoq desenvolveu um teatro baseado na visualidade, na imaginação, na brincadeira e no movimento do ator como principais recursos para desenvolver suas habilidades técnico-artísticas. Toda a sua metodologia sempre esteve comprometida tanto com o fazer cênico e artístico quanto com uma pedagogia para o desenvolvimento do treinamento do ator. Sua metodologia se baseia em sua experiência tanto nos esportes como no teatro e também no período em que frequentou a escola de Copeau, pois foi nessa época que Lecoq entrou em contato com a metodologia de Copeau e encontrou nela a sua grande influência, que se faz presente em toda a sua pedagogia teatral.

\footnotetext{
${ }^{48}$ Tradução para fins didáticos de Jessika D. Gomes.

49 Antonin Artaud (1896-1948) foi poeta, ator e diretor teatral francês. Sua obra teve grande influência dos movimentos de vanguarda do início do século XX, principalmente o surrealista. É considerado um dos renovadores do teatro francês nos anos 1930 e suas obras se tornaram referência na busca por uma restauração na linguagem teatral ao longo de todo século XX.

50 Jacques Copeau (1879-1949) foi um influente diretor de teatro, produtor, ator e dramaturgo francês. Foi fundador do famoso Théâtre du Vieux-Colombier, em Paris. Ele organizou sua escola de teatro ligada ao seu teatro, a Ecole du Vieux-Colombier. Assim, influenciou o desenvolvimento do teatro através do treinamento do ator. O teatro francês do século XX é marcado pela perspectiva de Copeau.
} 
Assim como Copeau, Lecoq interessou-se pela tradição do teatro com o objetivo de encontrar nos estilos de atuação os caminhos para redimensionar o fenômeno teatral.

\begin{abstract}
Ao comparar-se as metas, estratégias e técnicas de Copeau e Lecoq, é tentador superestimar as características comuns de seus trabalhos. Ambos identificaram o movimento e a brincadeira como conceitos centrais e elementos práticos em seu ensino; ambos focaram na máscara, no coro e na commedia dell'arte como instrumentos para educar o ator moderno, e - no caso da tragédia grega e da 'comédia italiana' - como um veículo para a inovação e renovação teatral. Ambos, também, eram comprometidos com metas educacionais mais amplas, além de um treinamento estreito e vocacional, acreditando que não se poderia fazer atores criativos e eficazes sem também educá-los 'para a vida'. Ambos, em outras palavras, parecem compartilhar um humanismo comum que se estende muito além do palco em si. (MURRAY, 2003, p. 31)
\end{abstract}

Além das características citadas acima por Murray (2003), Lecoq também herdou de Copeau a inspiração para a renovação das formas artísticas através da observação dos movimentos dos animais e da natureza. Todos esses elementos fundamentam a sua pedagogia de trabalho, que veremos mais adiante neste capítulo.

Porém, de todas essas características, acreditamos relevante, para a nossa investigação, destacar o seu desejo de desenvolver os atores em termos técnicos e artísticos. Lecoq tinha como objetivo que cada aluno-ator elaborasse uma investigação pessoal que se fundamentaria na própria vida e nas experiências pessoais. Dessa forma, o aluno-ator era convidado a desenvolver uma pesquisa sobre suas vivências, sua individualidade e seu próprio corpo em cena na elaboração de uma linguagem artística.

Essa preocupação com o desenvolvimento de uma linguagem cênica fundamentada no corpo e no gesto do ator, através do treinamento de habilidades técnico-artísticas, foi um fenômeno presente ao longo do século $X X$ e se realizou muito em decorrência dos fatores já expostos no capítulo um desta dissertação, como a crise do drama ${ }^{52}$, mas também em função de um redimensionamento do corpo e de suas funções tanto na vida cotidiana das pessoas como nas artes em geral. Em muitas teorias culturais ocidentais, o

\footnotetext{
${ }^{51}$ Tradução para fins didáticos de Jessika D. Gomes.

${ }^{52}$ Para maiores detalhes sobre a crise do drama, pode-se consultar o capítulo um desta dissertação.
} 
corpo é entendido como uma possibilidade de reconhecer a individualidade dentro das sociedades contemporâneas. Segundo Murray (2003):

\begin{abstract}
Uma pressuposição que todas essas variadas teorias culturais compartilham - e que é particularmente relevante para todas as formas de atividade artística - é que o corpo humano não é uma entidade biológica fixa, anatômica ou "dada por Deus". Mas sim, que o corpo carrega os traços de sua própria história - ele 'fala' sobre quem somos. Quando olhamos para corpos - incluindo os nossos próprios - nós vemos mais do que apenas carne, cabelo, sangue, músculos e assim por diante. Nós vemos biografia pessoal, as marcas de sofrimento ou alegria, e a impressão de classe, gênero, raça e todas as outras características e disposições que nos torna quem somos. Este é um insight - e compreensão - que situa-se no coração de qualquer teatro que escolha colocar em suas práticas o corpo, gestos e movimentos em primeiro plano. Aqui, talvez, uma conexão entre o crescimento do Teatro Físico e as outras forças culturais mais amplas identificadas acima é mais transparente. (MURRAY, 2003, p. 39)
\end{abstract}

Seguindo essas teorias culturais e esse fenômeno do corpo como biografia, Lecoq desenvolveu um teatro do corpo, um teatro físico fundamentado nos movimentos e gestos dos atores em cena, que encontrava na fisicalidade singular dos corpos o seu material de criação e composição, aliado à sensação física e à imaginação do ator. Um teatro do corpo que elabora sua narrativa através da fisicalidade do ator-bailarino, como nos aponta o crítico português António Pinto Ribeiro (1994) e que se encontra mais detalhadamente exposto no capítulo um desta dissertação.

Assim, seguindo as suas influências e com o objetivo de elaborar uma pedagogia que desenvolvesse as habilidades técnico-artísticas na criação de uma cena fundamentada no movimento, na imaginação e na sensação do ator sobre seu próprio corpo e suas possibilidades criativas e poéticas, Lecoq fundou, em 1956, em Paris, a sua própria Escola, a qual continua formando alunos até os dias atuais. Sua Escola se tornou o seu ponto de referência para o desenvolvimento de sua pedagogia e de seu teatro, que estão baseados na experiência, na fisicalidade e na imaginação de cada aluno-ator.

A sua Escola se tornou uma referência mundial como escola de formação de atores, tendo formado importantes artistas contemporâneos, como

\footnotetext{
${ }^{53}$ Tradução para fins didáticos de Jessika D. Gomes.
} 
Ariane Mnouchkine ${ }^{54}$ (1939-), Philippe Gaullier ${ }^{55}$ (1943-) e Philippe Avron ${ }^{56}$ (1928-2010). Primeiramente, a escola recebeu o nome de "Escola de mímica: formação do ator", depois se chamou "Mímica, Movimento, Teatro" e, desde 1988, é chamada École Internationale de Théatre Jacques Lecoq.

Ao olhar brevemente a trajetória de Lecoq, percebemos que ele promoveu um teatro do corpo e do movimento, no qual cada aluno-ator era convidado a exercitar o corpo e revelar através dele a sua imaginação e suas sensações na elaboração de uma atuação física. Assim, após conhecer sobre a história e as influências de Jacques Lecoq, vamos agora compreender um pouco sobre a pedagogia que é aplicada atualmente em sua Escola.

Figura 21 - Alunos de Lecoq em performance na sua Escola.

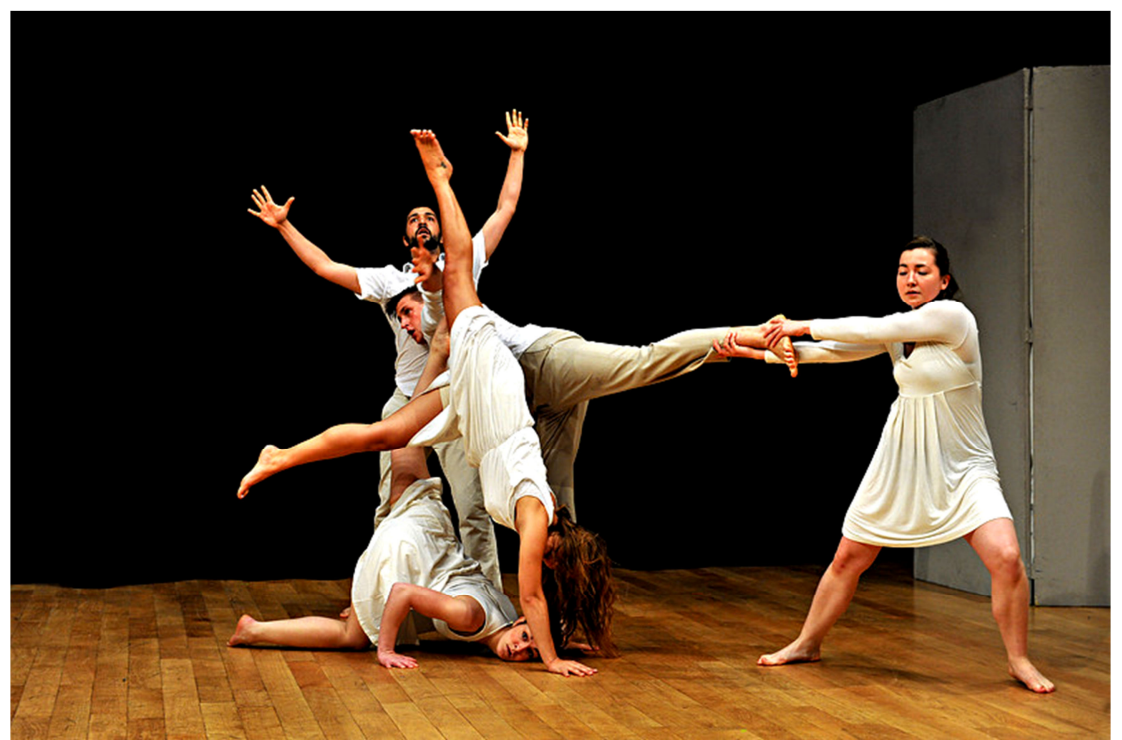

Fonte: http://www.tolgaypekin.book.fr/galeries/ecole-jacques-lecoq/790736. Acesso em 10 de junho de 2014.

\footnotetext{
${ }^{54}$ Ariane Mnouchkine (1939-) é diretora de teatro e cinema francesa, fundadora e diretora do Théâtre du Soleil em Paris (1964), coletivo teatral que se instalou na Cartoucherie de Vincennes em 1970.

${ }^{55}$ Philippe Gaulier (1943-) é um mestre francês, pedagogo e professor de teatro. Ele é o fundador da École Philippe Gaulier, uma prestigiada escola de palhaços franceses em Étampes, na França. Estudou com Jacques Lecoq em meados da década de 1960 e foi instrutor na École Jacques Lecoq no final de 1970.

${ }^{56}$ Philippe Avron (1928 -2010) foi ator francês e ainda jovem entrou em contato com Jacques Lecoq, tornando-se seu discípulo. Posteriormente, ensinou na escola de Lecoq.
} 
Figura 22 - Alunos de Lecoq em performance na sua Escola.



Fonte: http://www.ecole-jacqueslecoq.com/en/school_en-000001.html. Acesso em 10 de junho de 2014.

Figura 23 - Lecoq com seus alunos.

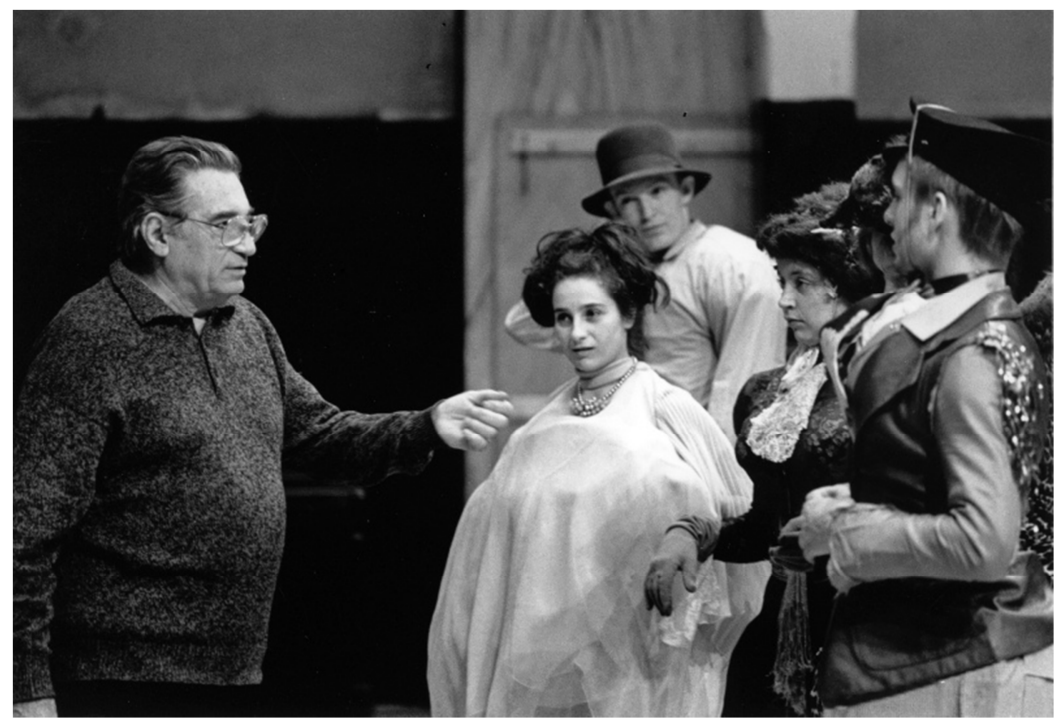

Fonte: http://www.ecole-jacqueslecoq.com/en/biographies_en-000004_t9.html Acesso em 10 de junho.

\subsection{Lecoq e a viagem pessoal: uma breve estruturação da pedagogia de}

\section{Lecoq segundo sua Escola}

A pedagogia de Jacques Lecoq, como mencionamos no tópico 3.1.deste capítulo, é fruto de sua própria experiência teatral e se fundamenta na sua École Internationale de Théatre Jacques Lecoq. A Escola tem por objetivo o 
desenvolvimento artístico e pessoal dos alunos, pois, para Lecoq, as vivências e experiências particulares, aliadas à observação e à imaginação, são as bases para o desenvolvimento técnico-artístico. Através do desenvolvimento de suas habilidades, cada aluno-ator poderá escolher as linguagens e estéticas teatrais que utilizará em suas criações artísticas.

A pedagogia de Lecoq está fundamenta na prática de sua Escola e em entrevistas, vídeos e livros nacionais e internacionais. No Brasil, são poucos os textos, livros e referências que encontramos sobre a pedagogia de Lecoq. Assim, para a estruturação dos conceitos e métodos utilizados em nossa investigação e práxis, nos baseamos em três referências bibliográficas: o livro 0 Corpo Poético, de Lecoq, traduzido para o português em 2010, e a dissertação e a tese da atriz, professora e diretora Cláudia Muller Sachs ${ }^{57}$ (2004; 2013).

No livro O Corpo Poético, encontramos uma estruturação consistente da pedagogia de Jacques Lecoq em textos de sua autoria elaborados em entrevistas realizadas pelos colaboradores e organizadores Jean Gabriel Carasso $^{58}$ e Jean-Claude Lallias. ${ }^{59}$ Sachs (2004), em sua dissertação, realiza um relevante levantamento e organização sobre os princípios da pedagogia de Lecoq que são aplicados em sua Escola. Já em sua tese (SACHS, 2013), a autora nos traz as contribuições da pedagogia e da metodologia de Lecoq para o trabalho do ator contemporâneo, com enfoque no desenvolvimento da imaginação na criação cênica. Ambos os estudos são fundamentados em sua

\footnotetext{
57 Cláudia Muller Sachs possui doutorado (UDESC/2013) e mestrado (UDESC/2004) em Teatro na Universidade do Estado de Santa Catarina (UDESC). Atualmente trabalha como bolsista PNPD no PPGAC - Programa de Pós-graduação em Artes Cênicas da UFRGS. Trabalha como atriz, diretora e professora de teatro, com ênfase em interpretação e direção teatral, movimento corporal, improvisação e preparação de ator. Estudou na École Internacional de Thèatre Jacques Lecoq (1992-1993). Pesquisa a maneira como determinadas práticas embasadas na pedagogia de Jacques Lecoq utilizadas em seu trabalho contribuem para o desenvolvimento da imaginação do ator e para as produções de caráter colaborativo a partir da ênfase no ator como autor. Fonte: http://buscatextual.cnpq.br/buscatextual/busca.do Acesso em 04 de junho de 2014.

58 Jean-Gabriel Carasso é ator, diretor, autor e diretor de televisão e pós-graduação do Instituto d'Etudes Politiques de Grenoble. Diretor da Associação Nacional de Pesquisa e Ação Teatral (ANRAT), em 1997. Professor da Faculdade de Estudos de Teatro da Universidade de Paris III-Sorbonne (em 1997). Fonte: http://www.librairiedialogues.fr/personne/jean-gabriel-carasso/682183/ Acesso em 2 de junho de 2014.

59 Jean-Claude Lallias é encarregado de missão para o desenvolvimento da educação artística no Ministério da Educação Nacional da França (1998). Professor de literatura no Instituto Universitário de Formação de Professores Créteil e Professor Associado de Ciências Humanas, atribuído ao Centro Nacional de Documentação da Educação (CNDP), Departamento de Artes e Cultura, Ministério da Educação Nacional (2005). Seus campos de pesquisa são nas áreas de teatro, juventude contemporânea e sua transmissão no ambiente escolar e treinamento em práticas teatrais e culturais no ensino. Fonte: http://www.librairiedialogues.fr/personne/jean-claude-lallias/589796/ Acesso em 2 de junho de 2014.
} 
experiência enquanto atriz, diretora e professora e como aluna na École Internationale de Théatre Jacques Lecoq.

Com base nessas referências, constatamos que Lecoq considerava a sua metodologia como uma viagem que tinha por objetivo o próprio percurso, estando em constante movimento. Ele também fazia uma analogia entre a pedagogia de sua Escola e os movimentos do mar.

Ainda que possamos dar a impressão, vistos de fora, de que fazemos
sempre a mesma coisa, na verdade tudo muda... mas lentamente!
Não andamos a grandes passadas, somos mais parecidos com o
mar: os movimentos das ondas, na superfície, estão mais visíveis do
que os que estão por baixo, mas todos esses movimentos vêm do
fundo. Na Escola há sempre essa ideia "submarina". Mesmo se,
algumas vezes, pomos a cabeça para fora, rapidamente
mergulhamos de volta, entre uma onda e outra. (LECOQ, 2010, p. 40)

A Escola apoia a sua pedagogia em dois eixos básicos: a pista de interpretar (a improvisação e suas regras) e a técnica dos movimentos e sua análise (LECOQ, 2010, p. 41). Nessas duas etapas, o percurso é complementado pelos denominados autocursos, que são os trabalhos desenvolvidos pelos próprios alunos, em pequenos grupos, nos quais os alunos criam e apresentam cenas a partir de temas específicos. A formação se desenvolve ao longo de dois anos: no primeiro ano, o aluno entra em contato com "os princípios básicos do jogo e da criação dramática, e no segundo a utilização destes princípios aplicados às diferentes tradições de jogo dramático, do melodrama, commedia dell'arte, bufão, tragédia e clown" (SACHS, 2004, p. 53).

Como a pedagogia de Lecoq se fundamenta no jogo tanto na improvisação quanto nos diferentes estilos de atuação, acreditamos ser importante entender como esse elemento é considerado por ele. Em sua metodologia, Lecoq se utiliza dos próprios significados das palavras jogo e jogador, com o objetivo de relacionar essas palavras com brincadeiras infantis, divertimento e espontaneidade para orientar os alunos. Segundo Sachs (2004):

A concepção de Lecoq de jogo é fundada numa aproximação que pode ser chamada de divertida ou improvisatória. Ele explora ao máximo os significados contidos nas palavras 'jogo' e 'jogador' entre a brincadeira das crianças e o drama, jogos e performances. Sua própria definição de jogo é a seguinte: 'quando, consciente da dimensão teatral, o ator pode formatar uma improvisação para os espectadores, usando ritmo, tempo, espaço, forma. (LECOQ, 2001, apud SACHS 2004, p. 52) 
A partir dessa breve definição de Lecoq (2001) sobre jogo, podemos perceber que para ele o jogo e a improvisação se interligam e se concretizam através do uso do ritmo, do tempo, do espaço e da forma, o que se relaciona diretamente com os fatores de movimento ${ }^{60}$ de Laban: espaço, tempo, peso e fluxo. Assim, percebemos que ambos acreditavam em uma improvisação na qual gestos, movimentos e ações são definidos pelo uso do corpo do atorbailarino dentro dos elementos peso, tempo e espaço.

Semelhante a Laban, que apresenta um extenso e complexo Sistema sobre os princípios de movimento, a pedagogia de Lecoq é ampla e se desenvolve ao longo desses dois anos em sua Escola, tendo como base a improvisação e a análise dos movimentos. Percebemos que o estudo sobre a metodologia das transferências se encontra nos elementos desenvolvidos ao longo do primeiro ano da Escola, no qual o aluno inicia sua pesquisa pessoal sobre uma interpretação silenciosa e adquire, ao mesmo tempo, tranquilidade e curiosidade para descobrir e estudar, entre outros aspectos, as dinâmicas da natureza. Nesta etapa da sua pedagogia, o aluno é convidado a investigar a criação teatral através dos elementos, das matérias, dos animais, das cores, das luzes, dos sons e das palavras, que são traduzidas para o corpo por meio de gestos e ações no trabalho de mimodinâmicas.

As mimodinâmicas compreendem o estudo das dinâmicas da natureza transferidas para o corpo do aluno através do ritmo, do peso e do espaço de seus movimentos e gestos. Assim, o corpo todo pode ser um personagem, uma máscara teatral que tem como características as dinâmica de cada elemento. $\mathrm{Na}$ pedagogia de Lecoq, todo esse processo tem por objetivo desligar o aluno de seus padrões habituais de interpretação realista e guiá-lo para uma atuação física na qual o seu imaginário e o seu corpo possam concretizar os elementos da natureza. Nesse estudo sobre a observação e as dinâmicas da natureza é que se insere o trabalho da metodologia das transferências, que compreende nosso recorte de investigação sobre a pedagogia de Jacques Lecoq e que se encontra exposta no tópico 3.3 deste capítulo.

\footnotetext{
${ }^{60}$ Todas as referências e noções sobre o Sistema de movimento de Rudolf Von Laban utilizadas ao longo deste capítulo se fundamentam em nossa práxis sobre o Sistema de Laban, exposta detalhadamente no capítulo dois desta dissertação.
} 
Ainda no primeiro ano da Escola, são estudados os diferentes estilos de interpretação com o uso de máscaras teatrais, de questões técnicas relativas ao estudo do movimento, desenvolvidas através da análise das improvisações, além de preparação corporal e vocal, de acrobacias dramáticas e de análises de ações físicas em cena.

Já no segundo ano da Escola, a pedagogia se desenvolve sobre a abordagem da linguagem dos gestos. Assim, o aluno é preparado para explorar os diferentes estilos de interpretação em toda a sua extensão e níveis de criação. Lecoq denomina este percurso como a viagem geodramática, que se realiza em três dimensões: extensão, elevação e profundidade. Após este processo, o aluno estuda os diferentes estilos de atuação que fazem parte da história do teatro. São eles: melodrama (os grandes sentimentos), a commedia dell'arte (comédia humana), os bufões (do grotesco ao mistério), a tragédia (o coro e o herói) e o $c l o w n^{61}$ (o burlesco e o absurdo). O aluno adquire uma formação embasada nos grandes estilos de atuação e cultiva uma técnica que é aplicada a diferentes níveis de interpretação e que desenvolve as habilidades técnico-artísticas do aluno com o objetivo de desenvolver uma atuação física, tendo como base o material artístico e poético do aluno. Seguem abaixo alguns dos métodos utilizados em sua pedagogia ao longo dos dois anos da Escola (LECOQ, 2010, p. 37):

- método evolutivo, que vai do mais simples ao mais complexo;

- método das transferências, que passa de uma técnica corporal a uma expressão dramática (justificativa dramática das ações físicas, transferências das dinâmicas da natureza para personagens e situações);

- aumento e diminuição do gesto, do equilíbrio à respiração;

- gamas e níveis de interpretação;

- união do gesto e da voz;

- economia de movimentos, acidentes e desvios;

- passagem do real ao imaginário;

\footnotetext{
${ }^{61}$ Como nosso recorte de pesquisa não compreende esses estilos de interpretação, sugerimos, para esclarecimentos adicionais sobre as definições dessas noções e expressões segundo a pedagogia de Jacques Lecoq, a leitura do livro O Corpo poético (LECOQ, 2010).
} 
- descoberta da interpretação e de suas regras (as regras nascem da própria interpretação);

- método das restrições (de espaço, de tempo e de número);

- prova técnica (o encadeamento de vinte sete movimentos);

- encomendas (são cenas que os alunos trabalham sozinhos e apresentam em aula);

- realização de espetáculos ligados aos temas estudados na escola.

Percebemos que toda a pedagogia de Lecoq é baseada no estudo da improvisação (jogo) e na análise dos movimentos, dos gestos e ações do corpo. Segundo ele, "o movimento, trazido pelo corpo humano, é nosso guia permanente nessa viagem que vai da vida ao teatro" (LECOQ, 2010, p. 43). Nesse sentido, acreditamos ser importante, para nossa investigação, ressaltar que toda sua metodologia se fundamenta sobre essa viagem pessoal à qual cada aluno-ator é convidado a embarcar e durante a qual cada um desenvolve uma pesquisa particular sobre seu próprio corpo, sua imaginação e suas sensações, que se tornam os guias de suas escolhas artísticas e estéticas. Segundo Lecoq, essas escolhas estão presentes tanto na vida como no teatro.

\begin{abstract}
O objetivo da Escola é a realização de um jovem teatro de criação, que trabalhe linguagens em que a interpretação física do ator esteja presente. $O$ ato de criação é suscitado de modo permanente, sobretudo por meio da improvisação, primeiro ponto de partida para qualquer criação. A Escola visa a um teatro de arte, mas a pedagogia do teatro é mais vasta que o próprio teatro. Na verdade, sempre concebi meu trabalho com um duplo objetivo: de um lado o interesse está no teatro; de outro, na vida. Sempre tentei formar pessoas que ficassem boas nos dois lados. (...) Uma das originalidades da Escola é fornecer uma base, tão ampla e permanente quanto possível, sabendo que, em seguida, cada um fará desses elementos seu próprio caminho. (LECOQ, 2010, p. 44)
\end{abstract}

Sendo assim, após esse breve contexto sobre a pedagogia de Lecoq, percebemos que essa viagem pessoal se relaciona diretamente com os objetivos de nossa pesquisa, que pretende encontrar no corpo, na imaginação e nas sensações de cada intérprete uma fisicalidade singular que sirva como material criativo e poético para o desenvolvimento de uma linguagem cênica.

Em nosso recorte de investigação, estudamos a pedagogia de Lecoq no que se refere à observação das dinâmicas da natureza, especificamente sobre a metodologia das transferências, pois pretendemos encontrar no corpo de 
cada atriz-bailarina possibilidades de criação de uma poética pessoal para além da lógica de interpretação de personagens ou máscaras teatrais. Assim, percebemos que o estudo dos elementos e dinâmicas da natureza nos proporciona o desenvolvimento de habilidades técnico-artísticas fundamentadas no aperfeiçoamento da imaginação para a elaboração de uma fisicalidade baseada na lógica corporal de cada intérprete. Enfatizamos, então, que a nossa práxis sobre a metodologia das transferências e esse processo, bem como suas definições, se encontram expostos a seguir.

\subsection{Estruturando a nossa própria viagem: a metodologia das}

\section{transferências e o estudo das dinâmicas da natureza}

A observação da natureza é um recurso fundamental na pedagogia de Lecoq. Ele acreditava que, ao observar o mundo externo, o aluno poderia reconhecer e identificar através dos movimentos da vida (elementos, cores, animais, entre outros) os próprios movimentos humanos. Assim, em seu trabalho desenvolvido com a denominada máscara neutra, ${ }^{62}$ que faz parte do primeiro ano de sua Escola, encontramos a metodologia das transferências. Nesse processo, os alunos são solicitados a se identificarem com a natureza através da aproximação das dinâmicas presentes nos quatro elementos: água, terra, fogo e ar, com o objetivo de concretizar, por meio de seus gestos e ações corporais, as dinâmicas de cada elemento.

\footnotetext{
O objetivo do ator é expandir o campo de suas referências e sentir todas as nuances que existem de uma matéria à outra e, até mesmo, dentro de uma mesma matéria. O pastoso, o oleoso, o cremoso... possuem dinâmicas diferentes. Desejo que os alunos entrem no gosto pelas coisas, exatamente como um gourmet reconhecer as diferenças sutis entre vários sabores. (LECOQ, 2010, p. 79)
}

Na metodologia das transferências, os alunos são convidados a estudar, além dos elementos da natureza, as dinâmicas das matérias, dos animais e das cores. Por meio da identificação com esses elementos, o aluno se apoia nas

\footnotetext{
62 "A máscara neutra é um objeto particular. É um rosto, dito neutro, em equilíbrio, que propõe a sensação física da calma. Esse objeto colocado no rosto deve servir para que você sinta o estado de neutralidade que precede a ação, um estado de neutralidade que precede a ação, um estado de receptividade ao que nos cerca, sem conflito interior. Trata-se de uma máscara de referência, um máscara de fundo, uma máscara de apoio sobre todas as outras máscaras.". (LECOQ, 2010, p. 69)
} 
dinâmicas da natureza para encontrar possibilidades expressivas de interpretar a própria natureza humana. "A meta é atingir um nível de transposição teatral, fora da interpretação realista" (LECOQ, 2010, p. 79). Lecoq (2010) acredita que o principal resultado do trabalho das transferências são os traçados que se inscrevem no corpo do ator e que encontram forma e expressão nas diferentes dinâmicas corporais experienciadas, que poderão servir como material criativo e artístico para o aluno-ator em suas escolhas e linguagens estéticas.

Além da metodologia das transferências, os elementos e as matérias da natureza são estudados na análise dos movimentos do corpo humano, na qual os alunos investigam tecnicamente os movimentos corporais da natureza: os elementos, as matérias e os animais. Este trabalho acontece paralelamente às identificações com a natureza, após os alunos improvisarem sobre os elementos. Por exemplo, os movimentos realizados na improvisação são retomados para serem estudados tecnicamente. Assim, os alunos experimentam a transposição para o corpo das diferentes dinâmicas que os elementos, as matérias e os animais possuem, como peso, forma, densidade, volume, resistência, e outras, como as fusões, as evaporações e as solidificações. Após este estudo, o aluno vivencia em seu corpo diferentes dinâmicas que são percebidas, conscientizadas e estruturadas segundo os aspectos de ritmo, espaço, forma e peso e que poderão servir como material criativo na elaboração de futuros personagens ou máscaras teatrais.

Ao término dessas experiências, os alunos terão sentindo todas as nuances possíveis entre as matérias e o interior de cada uma delas. (...) As dinâmicas das matérias tornam-se uma linguagem que thes servirá ao longo de seus trabalhos artísticos. (LECOQ, 2010, p. 137)

Esse estudo sobre cada elemento da natureza segundo as suas dinâmicas e os seus aspectos (ritmo, espaço, peso e volume) se relaciona diretamente com os fatores de movimento, que em Laban são utilizados para concretizar em movimentos e gestos o esforço, o impulso interno que antecede cada ação. Já em Lecoq, esses fatores são utilizados para traduzir no corpo do intérprete o interior de cada matéria e de cada elemento da natureza. 
Assim, em nossa investigação desenvolvida no Laboratório de Criação, ${ }^{63}$ utilizamos a metodologia das transferências $(\mathrm{MT})^{64}$ no que se refere à transposição para o corpo de elementos da natureza e à sua análise segundo as suas dinâmicas e seus aspectos de tempo, espaço, peso e volume.

Selecionamos este método da pedagogia de Lecoq com base em nossa experiência e nossos estudos sobre a MT, pois percebemos que, no processo de transposição de elementos (água, ar, fogo, terra), matérias, animais e cores, entre outros, para o corpo do intérprete, somos conduzidos a expandir nossas referências poéticas através do imaginário transposto para o corpo. Essa experiência é percebida e conscientizada através do estudo das dinâmicas de cada elemento e de seus aspectos de tempo, peso, espaço e volume, ampliando assim o vocabulário corporal de cada ator-bailarino que vivencia dinâmicas que fogem à lógica de representação de um personagem e se relacionam com a sensação e a lógica interna de cada elemento e cada matéria experienciada.

Acreditamos que a metodologia das transferências é um recurso muito importante para o desenvolvimento de uma corporeidade permeada pelo imaginário poético do intérprete e que colabora para o desenvolvimento de linguagens cênicas fundamentadas na fisicalidade singular de cada ator-bailarino.

Porém, devido ao nosso tempo de investigação, que compreendeu a duração desta pesquisa de mestrado, não poderíamos estudar todos os elementos e matérias propostas por Lecoq em sua pedagogia. Portanto, selecionamos seis elementos da natureza para serem desenvolvido em nossa práxis no Laboratório de Criação. Optamos pelos seguintes elementos: água, terra, fogo, ar, madeira e metal, pois esses elementos apresentam uma variedade quanto a suas dinâmicas, densidade, volume, forma e estados (líquido, gasoso, sólido). Apesar dos distintos formatos que esses seis elementos possuem na natureza, estabelecemos um quadro com as principais características presentes em cada um deles. Segue abaixo o quadro que elaboramos.

\footnotetext{
63 O Laboratório de Criação é o nome que utilizamos para definir nossa práxis sobre cada uma das metodologias, tanto de Rudolf Von Laban como de Jacques Lecoq, e se encontra detalhadamente explicado no capítulo dois desta dissertação.

${ }^{64}$ Vamos utilizar na escrita deste capítulo a abreviação de MT para nos referirmos à metodologia das transferências, para facilitar o estudo.
} 
Quadro 4 - Seis elementos da metodologia das transferências

\begin{tabular}{|l|l|}
\hline Elementos & Características \\
\hline Água & $\begin{array}{l}\text { Molécula resultante entre a união de hidrogênio e oxigênio, é líquida, } \\
\text { fria e úmida e pode apresentar os estados sólido, gasoso e líquido. }\end{array}$ \\
\hline Terra & $\begin{array}{l}\text { É um sólido da crosta terrestre, é sólida, fria e seca e pode ser mais } \\
\text { densa ou fina, como poeira. }\end{array}$ \\
\hline Ar & $\begin{array}{l}\text { É formado principalmente de oxigênio e nitrogênio, entre outros gases } \\
\text { da atmosfera, é gasoso, quente e úmido. }\end{array}$ \\
\hline Fogo & $\begin{array}{l}\text { É uma entidade gasosa emissora de radiação e energia, decorrente } \\
\text { da combustão, é um plasma, quente e seco. }\end{array}$ \\
\hline Metal & $\begin{array}{l}\text { É um material produzido a partir do tecido formado pelas plantas } \\
\text { lenhosas, com funções de sustentação mecânica, é orgânico, sólido, } \\
\text { de composição complexa. Apresenta grande diversidade de } \\
\text { características mecânicas, de densidade, higroscopia, cor, grão. }\end{array}$ \\
\hline & $\begin{array}{l}\text { É um elemento, substância ou liga caracterizado por sua boa } \\
\text { condutividade elétrica de calor, geralmente apresentando cor prateada } \\
\text { ou amarelada, e elevada dureza. Apresenta maleabilidade, } \\
\text { condutibilidade, elasticidade e brilho. }\end{array}$ \\
\hline
\end{tabular}

\subsection{Laboratório de Criação: nossa viagem pessoal sobre a metodologia das transferências}

Nossa práxis dentro do Laboratório de Criação sobre os seis elementos da metodologia das transferências seguiu a mesma rotina e metodologia estabelecida em nossa investigação sobre os fatores de movimento e ações de Laban, que se encontra exposta detalhadamente no capítulo dois desta dissertação, no tópico 2.3.

A base de nossa práxis seguiu sendo a improvisação segundo Rudolf Von Laban, na qual a improvisação se realiza a partir de uma experiência de movimento através do esquecer e rememorar dos fluxos do corpo. ${ }^{65}$ Porém, no caso de nossa investigação sobre a metodologia das transferências, as nossas improvisações aconteceram dentro dos limites estabelecidos pelas dinâmicas e qualidades presentes em cada elemento e não sobre as atitudes de cada fator

\footnotetext{
65 Para maiores esclarecimentos sobre a noção de improvisação que utilizamos em nossa práxis, sugerimos a leitura do tópico 2.3 , no capítulo dois desta dissertação.
} 
e ação, como em Laban. Sendo assim, nossa investigação sobre a MT de Lecoq aconteceu através das seguintes etapas:

1. Exploração livre dos seis elementos: nesta etapa, o trabalho se realizou através de uma improvisação corporal sobre os seis elementos (água, terra, fogo, ar, metal e madeira), dentro das características determinadas pelas dinâmicas e qualidades de cada elemento estudado. Primeiramente, utilizamos a imagem visual do elemento da natureza como estímulo para a improvisação, a fim de estabelecer uma possível identificação corporal com ele e traduzir suas qualidades em movimentos e gestos.

2. Estruturação de uma sequência de movimentos para cada um dos seis elementos: após a improvisação de cada elemento, selecionamos o material investigado e o estruturamos em uma pequena sequência de movimentos dotada de uma lógica própria e de um percurso espacial com início, meio e fim. Nesse processo de estruturação das sequências, cada elemento era então estudado e conscientizado segundo suas dinâmicas, sua densidade, sua flexibilidade, seu volume, sua cor e seus estados (líquido, gasoso e sólido).

3. Transmissão e aprendizado das sequências de movimentos individuais: após estabelecer a estrutura das sequências de movimento, cada uma das atrizes-bailarinas transmitia e aprendia a sequência da outra.

Durante nosso processo de investigação sobre a metodologia das transferências e seus respectivos elementos, percebemos que a utilização das imagens visuais sobre os elementos foi fundamental para acessarmos as dinâmicas e qualidades de cada elemento através de nossa sensação corporal e de nossa imaginação. Assim, foi através da sensação, aliada à imaginação, que experienciamos em nossos corpos as qualidades e dinâmicas de cada elemento e traduzimos essa experiência, ou, como nos propõe Lecoq, essa viagem pessoal, em movimentos e gestos que se configuram nas sequências individuais sobre cada elemento.

Nossa práxis sobre a metodologia das transferências e os seis elementos investigados resultaram em doze sequências de movimento. Todas elas se encontram fotografadas no DVD em anexo que acompanha esta 
dissertação. Abaixo seguem algumas fotografias das sequências de movimento.

Figura 24 - Atriz-bailarina Sissi Betina Venturin realizando a sequência de movimentos do elemento fogo.

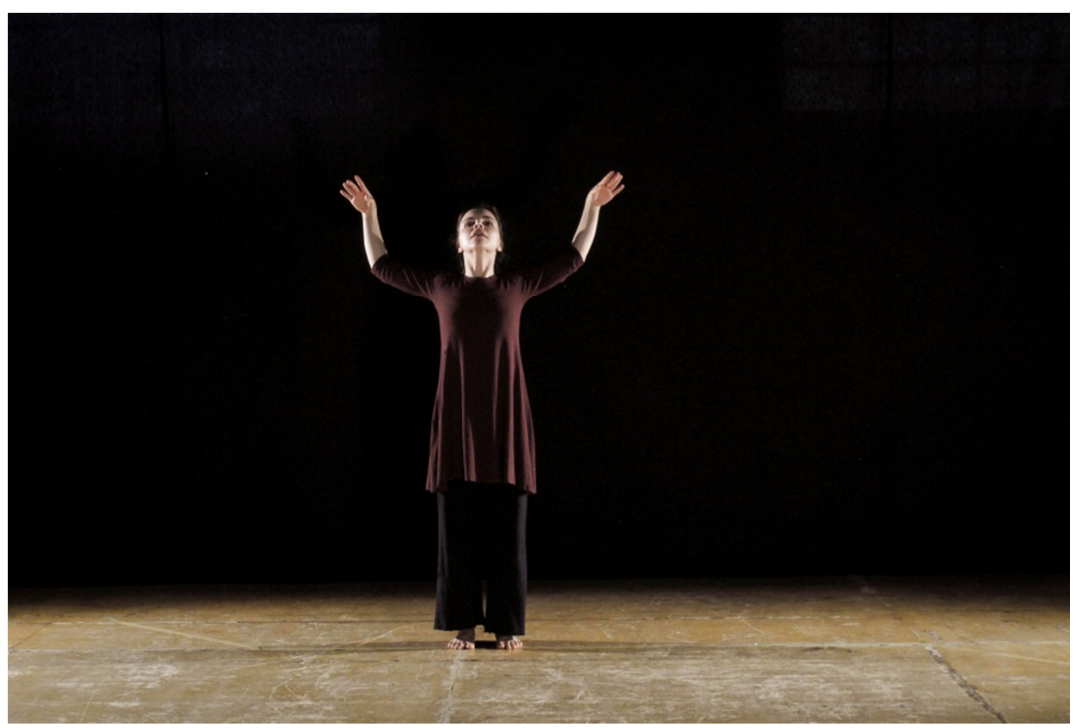

Fonte: Foto Di Pannacci

Figura 25 - Atriz-bailarina Sissi Betina Venturin realizando a sequência de movimentos do elemento água.

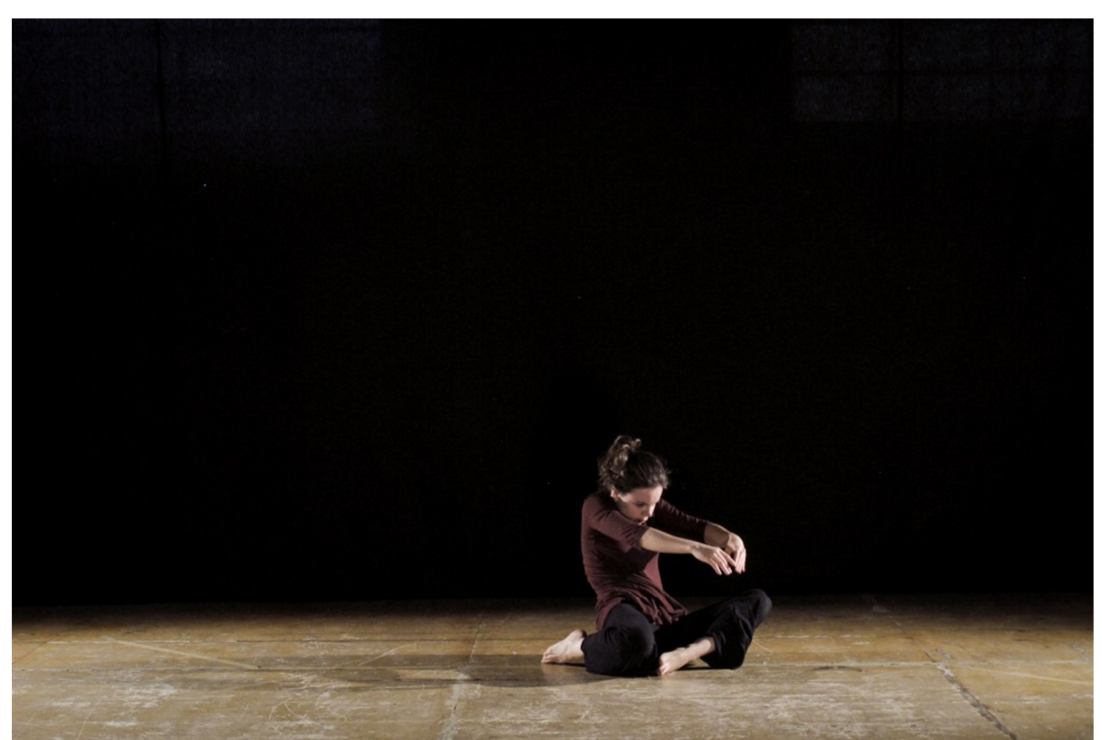

Fonte: Foto Di Pannacci. 
Figura 26 - Atriz-bailarina Kalisy Cabeda realizando a sequência de movimentos do elemento metal.

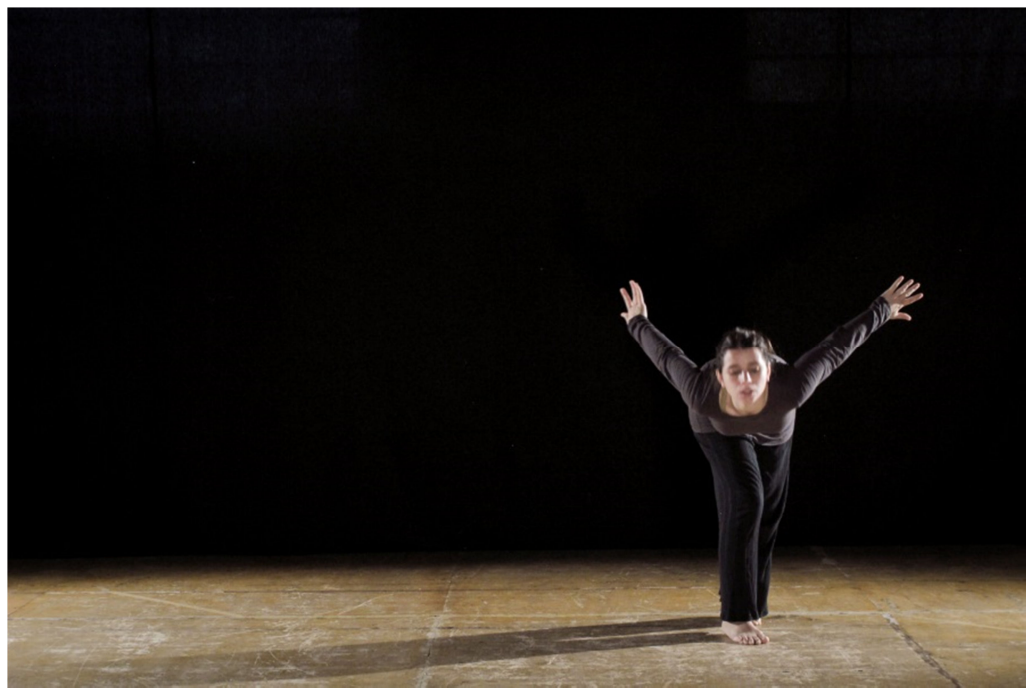

Fonte: Foto Di Pannacci.

Figura 27 - Atriz-bailarina Kalisy Cabeda realizando a sequência de movimentos do elemento Ar.

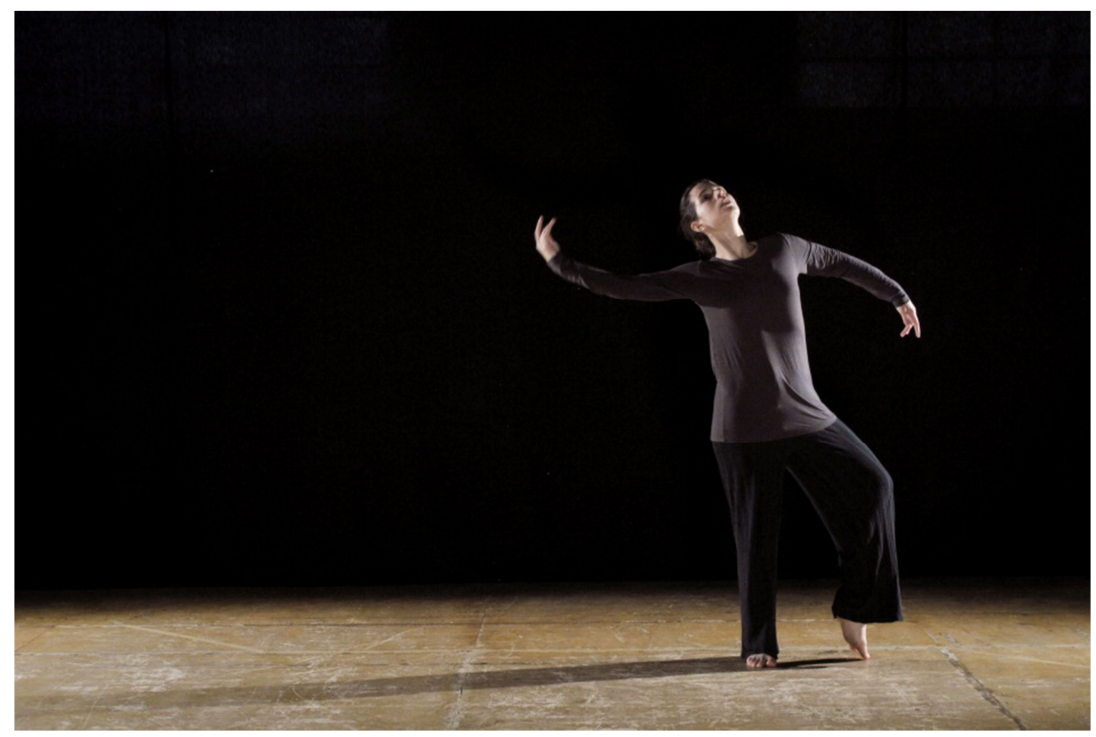

Fonte: Foto Di Pannacci.

\subsection{Laboratório de Criação: percepções sobre a nossa viagem pessoal} dentro da metodologia das transferências

Ao finalizar nossa práxis de investigação sobre a metodologia das transferências de Lecoq, percebemos que, ao longo de nossa viagem pessoal sobre cada elemento, alguns pontos se tornaram relevantes para nosso estudo 
sobre a corpo cênico e a fisicalidade singular presente nos movimentos de cada atriz-bailarina:

- Percebemos que visualizar a imagem de cada elemento da natureza antes de improvisar foi muito importante, pois auxiliou em nosso processo de reconhecer as características, qualidades e dinâmicas de cada elemento. A partir desse reconhecimento, nosso corpo e imaginação puderam acessar a sensação física que cada elemento propunha, permitindo traduzir essa sensação em movimentos, gestos e ações.

- Nossa experiência anterior no Laboratório de Criação sobre o Sistema Laban foi fundamental, pois através do estudo acerca dos fatores de movimento de Laban, peso, espaço, tempo e fluência, nossos corpos já estavam familiarizados com esses fatores, o que colaborou para estruturarmos cada um dos elementos da natureza dentro das dinâmicas de ritmo, espaço, peso, volume e densidade. Dessa forma, percebemos e conscientizamos cada um desses aspectos para assim realizar a transposição das dinâmicas de cada elemento da natureza através da estruturação das sequências de movimentos.

- Durante o processo de estruturação das sequências de movimento de cada elemento da natureza, percebemos que a imaginação colaborou muito para estabelecermos cada sequência dentro de uma lógica própria fundamentada nas sensações físicas que cada elemento despertava em nosso corpo. Através da imaginação, conseguimos memorizar em movimento e gesto as sensações, as dinâmicas e as qualidades de cada elemento.

- Sendo assim, em nossa investigação, a imaginação sobre cada elemento da natureza colaborou para a identificação corporal e, por consequência, para a transposição física e sensorial desses elementos em sequências de movimentos. Nesse processo de perceber o corpo através da imaginação, a transposição dos elementos para o corpo funcionou como um jogo, segundo a definição de Lecoq (2001), ${ }^{66}$ pela qual o jogo é uma forma de elaborar uma improvisação dentro dos aspectos ritmo, peso, forma e espaço. Foi através da improvisação que

\footnotetext{
${ }^{66}$ A definição de jogo que estamos utilizando segundo Lecoq (2001) encontra-se no tópico 3.2 deste capítulo.
} 
combinamos diferentes aspectos de cada elemento, como imagem visual, dinâmica, peso, espaço, volume e densidade, na elaboração das sequências de movimentos. Dialogamos, assim, com a pedagogia de Lecoq, na qual a imaginação e o jogo são fundamentais para a pesquisa pessoal de cada aluno-ator e de suas possibilidades criativas e artísticas na elaboração de uma atuação física. Segundo Sachs (2013):

Pelo mecanismo de associação de imagens, a atenção passa da observação de seu próprio corpo para uma visão mais ampla, do em torno, da dinâmica do movimento, de modo a permitir que as ideias surjam ou ainda, investindo-os com um sentido, numa explícita tentativa de aliar o movimento físico à imaginação (SACHS, 2013, p. 123)

- Na etapa três de nossa metodologia, transmissão e aprendizagem das sequências de movimento, percebemos que cada atriz-bailarina transpõe para seu corpo diferentes aspectos relacionados a cada elemento da natureza, pois cada uma realiza uma síntese de sua própria experiência sobre cada elemento estudado, o que resulta em diferentes sequências de movimentos que têm como matriz o mesmo estímulo criativo (o elemento água, por exemplo). Sendo assim, ao aprender a sequência individual uma da outra, enriquecemos e ampliamos nossas possibilidades corporais, pois exercitamos a habilidade de transpor para nossos movimentos e gestos a lógica corporal criada por outra pessoa e que apresenta características e qualidades singulares.

- Percebemos também que a dinâmica corporal proposta por cada elemento da natureza nos possibilitou experienciar diferentes qualidades físicas, expressivas e cinestésicas em nossos corpos e isso é muito importante enquanto possibilidade criativa e artística. Através dessas diferentes dinâmicas corporais, fomos reconhecendo, percebendo e nos conscientizando das qualidades artísticas e poéticas que estão presentes no corpo de cada intérprete e que fazem parte das matizes individuais de movimento de cada atriz-bailarina.

Para finalizar, gostaríamos de destacar que, no processo de investigação sobre a metodologia das transferências de Lecoq, nossas improvisações foram fundamentadas na imaginação sobre os elementos da natureza e foi a partir dela que traduzimos para o corpo as sensações, as 
dinâmicas e as atmosferas presentes em cada elemento estudado. Ao transpor corporalmente as imagens e sensações que os elementos da natureza suscitaram em cada uma de nós, percebemos que esses elementos e paisagens da natureza que imaginamos faziam parte de nossas referências pessoais. São nossas vivências sobre cada elemento que fazem parte de nossa história pessoal e que, ao improvisarmos sobre cada um deles, essas vivências retornam e são traduzidas em movimento, gesto e sensação.

É como se, através da experiência sobre cada elemento da natureza, pudéssemos imergir em nossas próprias recordações e ativar assim nossas sensações físicas e cinestésicas. É ao investigar cada elemento da natureza que mergulhamos em nosso próprio corpo, imaginação e vivências pessoais, que retornam em forma de gestos e ações no tempo e no espaço. Esse aspecto se relaciona diretamente com o esforço de Laban, pois o esforço que antecede toda a ação nasce da sensação interna do ator-bailarino e se concretiza através dos gestos e movimentos.

Dessa forma, na exploração sobre os elementos da natureza, fomos reconhecendo o interior de cada elemento e adentrando em nossas sensações, nossas próprias lembranças e vivências, que se configuraram como nossa viagem pessoal sobre os elementos, as matérias, a natureza que habita cada um de nós.

Sendo assim, em nossa práxis sobre a improvisação dos elemento da natureza, desenvolvemos nossa imaginação através da experiência do corpo. $\mathrm{Na}$ investigação sobre cada elemento, fomos modificando nossa matéria coporal, pois o corpo também é natureza, é elemento e matéria palpável de modificação. Ao traduzir os elementos em movimentos e gestos, transformamos nosso próprio corpo, que também é matéria, e através dessa experiência física, imaginativa e cinestésica, traduzimos nossas vivências pessoais sobre cada elemento. Desse forma, fomos configurando e reconhecendo nosso material criativo e artístico em um viagem pessoal na qual vamos elaborando nossa própria fisicalidade na construção de uma corporeidade singular de gestos e movimentos que determinarão a poética particular de cada ator-bailarino. 
sua criação pessoal, a sua poética, que também está relacionada ao estilo. (SACHS, 2013, p. 91)

\subsection{Laboratório de Criação, percepções finais: a experiência em Laban e a viagem pessoal em Lecoq}

Ao finalizar nossa práxis sobre a metodologia das transferências, concluímos a investigação em nosso Laboratório de Criação. Deste processo resultaram ao todo quarenta e cinco sequências de movimento, pelas quais experienciamos a eukinética do Sistema de movimento de Laban e a metodologia das transferências de Lecoq. Posteriormente, as sequências de movimento foram utilizadas como material criativo e poético na elaboração do exercício cênico de composição que se constituiu como a última etapa de nossa pesquisa e se encontra detalhadamente exposta no capítulo quatro desta dissertação.

Além das considerações e percepções já mencionadas ao longo de nossa investigação dentro do Laboratório de Criação, gostaríamos de ressaltar alguns pontos que se tornaram fundamentais em nosso processo criativo.

- As sequências de movimentos elaboradas ao longo de nossa pesquisa podem ser percebidas como um material primário e estruturante, que posteriormente serviu como base para a nossa criação artística (o exercício cênico de composição). Esse material bruto que se originou a partir de nossa experiência sobre o Sistema de movimento de Rudolf von Laban e a pedagogia de Jacques Lecoq configurou-se como um mapa corporal pessoal, no qual foi possível perceber e conscientizar certas habilidades técnico-artísticas no corpo cênico de cada atrizbailarina. Através dessas habilidades, reconhecemos nossas "paisagens corporais" que serviram posteriormente como material criativo e poético na elaboração do exercício cênico de composição.

- Contudo, sabemos que esse material originado dentro do Laboratório de Criação sobre cada uma das metodologias estudadas foi fruto de uma investigação pessoal de cada intérprete baseada na experiência e na descoberta de nossas habilidades físicas e expressivas, e muito ainda é preciso estudar, pesquisar e desenvolver no que se refere às nossas 
habilidades e nosso corpo cênico. Porém, percebemos que elaboramos um material interessante, pelo qual nos aproximamos e reconhecemos nosso material criativo pessoal, que faz parte da fisicalidade singular de cada intérprete e serviu como base para a elaboração de uma criação cênica.

Ao praticar os exercícios e as dinâmicas de cada método estudado (Laban, Lecoq), elaboramos estruturas básicas que continham os princípios de cada metodologia. Nesse percurso, descobrimos e lapidamos em nosso corpo certas habilidades artísticas e poéticas que nos conduziram ao reconhecimento de nosso material criativo pessoal, de nossas próprias "paisagens corporais".

Nesse sentido, percebemos que todo nosso percurso de investigação foi muito importante, pois exercitamos em nossos corpos diferentes possibilidades físicas, expressivas, cinestésicas e artísticas. Contudo, destacamos de nossa experiência sobre cada metodologia estudada a utilização de imagens visuais, tanto em Laban como em Lecoq: as imagens da cinesfera, plano da porta, plano da mesa e plano roda (Laban) e os elementos da natureza (Lecoq). Através da imaginação, exercitamos nosso corpo ao acionar estímulos sensíveis que nos permitiram perceber sensações físicas sutis que foram expressas através da fisicalidade singular de cada atriz-bailarina. Assim, percebemos que a imaginação é muito importante no processo criativo, pois ela interfere e amplia os resultados cênicos corporais, tanto em dança como em teatro. Portanto, como o corpo, ela também deve ser exercitada e treinada. Segundo Ariane Mnouchkine, a imaginação, o corpo e os sentidos devem exercitados de forma atlética na formação do ator:

Pedimos aos atores que sejam "visionários", que dêem consistência,
que concretizem poemas, imagens, visões; eles devem levar em
conta o mundo exterior - aquele no qual se passam a peça e o
espetáculo- e de seu mundo interior - o do personagem. É uma tarefa
cansativa, que não deixa intactos nem seu corpo, nem sua alma, uma
tarefa atlética para o corpo, a imaginação e os sentidos.
(MNOUCHKINE, 1982, apud ASLAN, 1985, p. 231)

Ao desenvolvermos o corpo cênico e suas habilidades físicas, sensoriais, expressivas e imagéticas, reconhecemos nosso material criativo e poético, que servirá como base para trabalhos tanto na dança como no teatro.

\footnotetext{
${ }^{67}$ Mnouchkine em declarações no livro de Odete Aslan (1985). Tradução para fins didáticos de Sofia Salvatori.
} 
Este material, através dos gestos, movimentos e ações realizados em cena, transmite nossas percepções e sensações sutis, permeadas também por nossas experiências e vivências pessoais.

Sendo assim, percebemos que a imaginação é um veículo importante para acessarmos nossas percepções sutis, que podem ser concretizadas através da fisicalidade e do corpo cênico de cada intérprete. Em nossa experiência no Laboratório de Criação, tanto em Laban como em Lecoq, mas especialmente na investigação sobre a metodologia das transferências de Lecoq, desenvolvemos e lapidamos nossa imaginação.

O trabalho sobre os elementos da natureza e suas camadas mais sutis despertou a imaginação, a percepção e a consciência para expressarmos nossas sensações pessoais permeadas por nossas próprias impressões do mundo e da natureza. Essas sensações estão impressas em cada intérprete e se revelaram nesse processo de transposição dos elementos da natureza para o corpo, expressando dessa forma a realidade que o indivíduo carrega em si através do que Lecoq chama de poema em movimento: "a verdadeira colocação de um poema em movimento, algo que a tradução por meio de palavras não consegue praticamente jamais alcançar" (LECOQ, 1997, apud SACHS, 2013, p. 40).

Assim, o poema em movimento de Lecoq se relaciona diretamente com os princípios de Laban sobre a improvisação como uma experiência na qual o bailarino é permeado por fluxos de sensações que também carregam as impressões do bailarino sobre o mundo, os objetos, a natureza. Segundo Launay (1999), é através do saber-sentir que o bailarino embarca no fluxo de suas percepções e acessa as sensações sutis da natureza, dos animais:

O saber-sentir repousa sobre um não querer e um não-saber. Ele é
fruto de um trabalho do tempo sobre o sujeito. Seu resultado é
aleatório. Ele se forma através dos movimentos cotidianos (ou não)
de corpos comuns a partir de dados inertes, passados ou presentes.
Ele permitiria perceber as afinidades mal definidas entre o gesto de
trabalho e o movimento dançado, a natureza e as coisas (a potência
do salto do animal, o balançar de uma planta, a formação do cristal, a
energia contida em uma mesa de madeira), para criar seres que
sejam devir-coisas, devir-animais. (LAUNAY, 1999, p. 81)

É através dessa experiência de saber-sentir que Laban convoca o atorbailarino a percorrer seus próprios fluxos de movimento em uma viagem sobre 
o seu interior e suas paisagens corporais em busca do que Launay (1999) denomina de região do silêncio: "A descoberta da "região do silêncio" é propriamente falando, uma viagem interior, já que esse interior se modifica sem parar, em função do exterior" (LAUNAY, 1999, p. 85).

Sendo assim, tanto Laban como Lecoq convidam o ator-bailarino a embarcar na experiência de uma viagem pessoal sobre o interior de suas sensações e paisagens pessoais para encontrar nas percepções sutis de seus fluxos de movimento a corporeidade que Ihe permitirá escrever o poema em movimento em Lecoq e coreografar o poema do esforço em Laban.

Dessa forma, realizamos nossa viagem pessoal e elaboramos um mapa corporal através da investigação sobre o Sistema de movimento de Laban e a pedagogia de Lecoq, mapa este que compreende as quarenta e cinco sequências de movimento e pelo qual seguimos nossa viagem na elaboração de nosso exercício cênico de composição que se encontra exposto no quarto e último capítulo desta dissertação. 


\section{CAPÍTULO 4 - OS TRAJETOS DO PERCURSO CRIATIVO: O SENTIDO SE SENTE COM O CORPO}

Desta maneira rastros irão sendo deixados como que em uma trilha.
Metaforicamente, é como que as pegadas deixadas fossem
identificadas, talvez como vivências, como as histórias pessoais, como
as interações que irão configurar os enquadramentos, os focos e os
prismas através dos quais os seres-humanos aspiram e caminham.
Traços, quiçá que foram acompanhados em outros processos, inspiram
o intérprete-criador a novas trajetórias. (PEREIRA, 2012, p. 4)

Como nos propõe Pereira (2012), os traços e rastros que os processos criativos vão deixando no corpo do ator-bailarino são como pistas que guiam nosso percurso e levam à construção de novas trajetórias. Sendo assim, após realizar o estudo dentro dos Laboratórios de Criação, fomos trilhando nossos passos através dos resultados conquistados nessa caminhada e seguimos para a criação de uma nova trajetória: a elaboração do exercício cênico de composição.

Depois de realizar a pesquisa e a estruturação das quarenta e cinco sequências de movimento a partir de conceitos e práticas encontradas no Sistema Laban e na pedagogia de Lecoq, respectivamente, foi possível reconhecer em nossos corpos certas habilidades técnico-artísticas, como precisão, atenção, intenção, ritmo, condensação e imaginação, que foram desenvolvidas com base no estudo dos quatro fatores de movimentos de Laban e da metodologia das transferências de Lecoq.

Sendo assim, através dessas habilidades, estabelecemos uma consciência sobre nossos corpos, pois, ao trabalharmos imbuídos por nossa percepção, fomos modificando nossa visão e sensação tanto interna como externa do corpo e criando, a partir delas, as sequências de movimentos. Nessa direção, podemos estabelecer nosso percurso até aqui.

Assim, por meio da investigação realizada nos Laboratórios de Criação, desenhamos uma espécie de mapa corporal interno que guiou nossa trajetória criativa na elaboração de nosso exercício cênico. Através da percepção, despertamos a consciência sobre nossas possibilidades corporais e elaboramos/visualizamos/sentimos a geografia interna e externa de nossos corpos por meio da experiência de uma viagem pessoal por nossas "paisagens corporais". 
Como um mapa, que possui suas direções, topografias e paisagens, através da consciência sobre nossos corpos começamos a delimitar nosso próprio mapa perceptivo corporal, que por consequência modificou também nossa sensação física sobre o corpo. Desta forma, após estabelecer esse mapa, foi possível ter uma visão geral de nossos corpos e dos trajetos físicos e expressivos que tínhamos percorrido até aquele momento. Então, passamos a trilhar nossos trajetos com o objetivo de traçar um percurso, um caminho em direção ao processo de criação cênica, utilizando esse mapa que nos guiou na criação de metáforas corporais dentro da construção do exercício cênico. Segundo Ostrower (2013):

\begin{abstract}
Seu caminho cada um terá que descobrir por si. Descobrirá, caminhando. Contudo, jamais seu caminhar será aleatório. Cada um parte de dados reais; apenas, o caminho há de lhe ensinar como os poderá colocar e com eles irá lidar. Caminhado, saberá. Andando, o individuo configura o seu caminhar. Cria formas, dentro de si e em redor de si. E assim como na arte o artista se procura nas formas da imagem, criada, cada individuo se procura nas formas do seu fazer, nas formas do seu viver. Chegará ao seu destino. Encontrando, saberá o que buscou. (OSTROWER, 2013, p. 76)
\end{abstract}

Nesse caminhar que se descobre "caminhando", possuíamos como "dados reais", até então, o nosso mapa corporal correspondente às quarenta e cinco sequências de movimentos, no qual nos baseamos para realizar o exercício cênico. Como Ostrower (2013) nos fala, esse caminho se descobre andando, fazendo e experimentando; foi nesse sentido que seguimos nossa caminhada rumo à criação. Optamos por experimentar as sequências de movimentos combinando-as umas com as outras com o objetivo de construir células coreográficas que pudessem ser posteriormente organizadas em uma composição cênica. O nosso material de base foram as sequências de movimentos construídas ao longo dos Laboratórios de Criação, as quais testamos em diferentes combinações, que deram origem às células coreográficas que se constituíram em nosso exercício cênico de composição, cujo título foi $O$ Sentido se Sente com o Corpo, ${ }^{68}$ nome que surgiu a partir de um dos poemas utilizados em cena, da poeta brasileira Josely Vianna Baptista (1957-), e que será exposto em detalhes no tópico 4.3 deste capítulo. Percebemos que, ao percorrer nosso mapa corporal, chegamos a distintas

\footnotetext{
${ }^{68}$ Frase retirada do poema Zen-Riders, de Josely Vianna Baptista (1992).
} 
paisagens ao longo de nosso processo criativo, o qual pode ser dividido em quatro diferentes trajetos:

1. Combinação das 45 sequências individuais de movimentos em células coreográficas;

2. Organização das células coreográficas em um roteiro cênico;

3. Relação entre as diferentes camadas: o roteiro cênico, a poesia textual, a textura sonora e a iluminação;

4. Apresentação do exercício cênico de composição O Sentido se Sente com o Corpo para o público.

Cada um desses trajetos será exposto a seguir com o intuito de refletir sobre as escolhas artísticas e estéticas que nos conduziram ao longo de nosso percurso criativo, assim relacionando nosso processo com as questões apontadas ao longo dessa dissertação no que diz respeito à criação com base na poética corporal.

Acreditamos ser relevante frisar que as palavras não podem comportar todo o valor da experiência criativa, mas permitem a reflexão sobre algumas escolhas estéticas que permearam o nosso fazer. Através do exercício cênico, fomos conduzidos a fazer/realizar e foi por meio dessa ação que chegamos a novas percepções sobre nossos corpos, o que nos permitiu refletir sobre o corpo cênico e sua habilidade de criar movimentos e gestos repletos de poesia. Segundo Salles (2011), o artista age e é no seu agir que ele concretiza sua operação poética, que é:

Uma atividade ampla que se caracteriza por uma sequência de
gestos, que geram transformações múltiplas na busca pela
formatação da matéria-prima de uma determinada maneira, e com um
determinado significado. Processo que envolve seleções,
apropriações e combinações, gerando transformações e traduções.
Gestos formadores que se revelam, em sua intimidade, como
movimentos transformadores da mais ampla diversidade. (SALLES,
2011 , p. 35)

Através da elaboração de gestos formadores e transformadores, como nos propõe Salles, seguimos nossa jornada em busca de nossa operação poética: a criação cênica baseada em metáforas corporais. A matéria-prima foi o corpo cênico imbuído na práxis vivenciada nos Laboratórios de Criação a partir de conceitos e práticas encontradas no Sistema Laban e na pedagogia de Lecoq. 


\subsection{Primeiro trajeto: combinação das sequências individuais de movimentos em células coreográficas}

Nossos primeiros passos foram em direção à combinação das sequências de movimentos resultantes do estudo realizado nos Laboratórios de Criação. Seguimos nossa rotina de trabalho ${ }^{69}$ com o objetivo de combinar entre si um total de 45 sequências: 15 resultantes das $\mathrm{ABE}^{70} ; 12$ resultantes das $\mathrm{Al}, 6$ resultantes dos IA e 12 resultantes da MT. Todas as sequências desenvolvidas nos Laboratórios de Criação encontram-se em anexo no DVD que acompanha esta dissertação de mestrado. Desta forma, a partir desse material criativo, começamos a trabalhar sobre ele com o intuito de extrair pequenas células coreográficas, com início, meio e fim, que possuíssem uma lógica física e expressiva.

$\mathrm{Na}$ criação das células coreográficas, fomos relacionando as sequências em pares ou trios, que algumas vezes dialogavam por contraste ou semelhança, outras vezes por apresentarem tensões corporais distintas, ou ainda por se enquadrarem no deslocamento pelo espaço, pela diferença ou semelhança de ritmo, ou mesmo por percebermos facilidades ao executar as sequências uma após a outra. Assim, foi possível recortar, colar, desmanchar, dividir e ajustar cada sequência de movimentos de acordo com o que percebemos e intuímos de cada coreografia e isso contribuiu para o processo de criação. Através do material (as sequências de movimentos) conhecido por nossos corpos, foi natural realizar o processo de criação das células coreográficas. Nesse sentido, percebemos a importância de havermos elaborado um material de base prévio: as sequências. Esse aspecto contribuiu muito para todo o processo de criação, pois partimos de algo concreto, ou seja, os movimentos que compunham cada sequência, utilizando o corpo como principal suporte criativo.

\footnotetext{
${ }^{69}$ A nossa rotina de trabalho encontra-se exposta no capítulo dois desta dissertação, no tópico 2.3.

${ }^{70}$ As siglas ABE, AI, IA e MT encontram-se explicadas nos capítulos dois e três desta dissertação, nos tópicos 2.5, 2.5.2, 2.5 .3 e 3.3 e se referem, respectivamente, às ações básicas de esforço, ações incompletas e ímpetos de ação do Sistema de movimento de Rudolf Von Laban e à metodologia das transferências da pedagogia de Jacques Lecoq.
} 
Durante esse processo, algumas sequências foram realizadas na íntegra, outras foram recortadas, excluídas ou incluídas. Na medida em que decidimos por um formato, ou seja, que ordenamos as sequências em células coreográficas, inevitavelmente impedimos que outras composições surgissem, pois ao escolher uma possibilidade, excluímos todas as outras; é nesse movimento de construir que também destruímos. Segundo Ostrower (2013):

Temos de levar em conta que uma realidade configurada exclui outras realidades, pelo menos em tempo e nível idênticos. É nesse sentido, mas só e unicamente nesse, que, no formar, todo construir é um destruir. Tudo que num dado momento se ordena, afasta por aquele momento o resto do acontecer. (OSTROWER, 2013, p. 26)

Sendo assim, ao ordenar as sequências de movimentos em células coreográficas, realizamos escolhas que nos foram possíveis a partir do vocabulário corporal estipulado (45 sequências de movimentos), da consciência, da intuição, da sensibilidade e da percepção, que nos guiaram nesse primeiro trajeto de composição.

Percebemos que a combinação entre as sequências aconteceu de forma precisa e consciente, pois, ao executarmos cada movimento, fomos analisando como relacionar cada parte. A combinação também se deu de forma intuitiva, percebendo os chamados insights de como unir cada movimento através de ideias e gestos que surgiram no momento da criação. Ao combinar as sequências, as ordenamos em células coreográficas que possuíam uma forma e uma lógica própria, tanto quanto à sua execução no espaço quanto à sua sensação corporal.

Nessas ordenações, certos aspectos são intuitivamente incluídos como "relevantes", enquanto outros são excluídos como "irrelevantes". Selecionados pela importância que têm para nós os aspectos são configurados em uma forma. Nela adquirirão um sentido talvez inteiramente novo. (...) Sentimos que a ordenação concreta a que chegamos abrange a razão de ser da situação, abrange toda a sua lógica íntima, o verdadeiro sentido. É o insight, a visão intuitiva. (OSTROWER, 2013, p. 67)

Nesse percurso criativo, algumas dificuldades surgiram, pois até 0 momento havíamos realizado as sequências dentro de um estudo corporal nos Laboratórios de Criação, em que cada sequência de movimentos foi criada com uma qualidade corporal, ou melhor, uma tensão corporal, um ritmo, uma dinâmica espacial própria de cada uma das atrizes-bailarinas. Ao unir as 
sequências, encontramos dificuldades em manter as tensões corporais, que eram bem definidas quando realizadas isoladamente, o tempo de execução e a precisão dos movimentos no espaço. Neste trabalho de relacionar um movimento a outro e ir ordenando em pequenas estruturas coreográficas, algumas tensões corporais não foram executadas e perdemos a precisão em movimentos que antes eram bem delineados (início, meio e fim), pois, na medida em que se uniam a outra sequência, ajustes se faziam necessários.

O ritmo e o tempo foram questões relevantes. Mesmo na criação de pequenas células de movimentos, o ritmo de cada sequência permanecia com o tempo de execução que era realizado quando a sequência era executada isoladamente. Assim, ao unir as sequências, percebemos certa fragmentação na sua execução, bem como certas pausas e quebras que não eram necessárias na coreografia. No trecho abaixo, extraído do diário de campo desta pesquisa, fica exposta esta dificuldade:

\begin{abstract}
Percebemos que ainda estamos fazendo as sequências no tempo em que elas foram criadas, pois mesmo unidas às sequências parecem manter o tempo de execução que tinham isoladamente. É necessário encontrar outras dinâmicas e ritmos, para as ligações ficarem mais fluídas e conectadas umas com a outra. Precisamos encontrar um tempo menos fragmentado, separado, como se a gente esperasse terminar uma coisa para iniciar outra e estabelecer uma dinâmica em que os movimentos fiquem ligados uns com os outros de forma mais natural.

Acreditamos que a trilha sonora será de grande importância para modificar e trazer outras nuances de tempo, como o rápido, o lento e encontrar outros fluxos que a coreografia necessita para além da execução das sequências, um fluxo que encadeie os movimentos. (trecho extraído do diário de campo de Kalisy Cabeda, em 02/07/2013)
\end{abstract}

Sendo assim, para auxiliar nas dificuldades que foram surgindo, realizamos a prática de registrar cada célula coreográfica através da câmera de vídeo. Ao finalizarmos uma criação, filmávamos e depois assistíamos o material que havia sido trabalhado em cada encontro. Esta se mostrou uma prática muito importante e que nos auxiliou na correção de muitos detalhes, como aspectos espaciais e temporais dos movimentos, bem como na precisão das composições coreográficas. Com o auxílio do vídeo foi possível visualizar externamente cada sequência que criamos e ver além da percepção interna de estar executando os movimentos, assim era visível, através do vídeo, o que precisava ser modificado, ajustado e aperfeiçoado. 
O vídeo também foi importante porque, na medida em que fomos visualizando as combinações entre as sequências de movimentos, percebemos certos movimentos que retornavam, como, por exemplo, o gesto de um braço que aparecia da mesma forma em diferentes combinações. Ao percebermos esses gestos que se repetiam, foi-se estabelecendo certa unidade de movimentos, aos poucos construindo um universo comum de linguagem. Percebemos que esses movimentos que retornavam faziam parte de nosso repertório corporal e de nossos padrões de movimento, pois cada pessoa possui uma personalidade e uma individualidade que pode ser visualizada através de seus gestos expressivos.

Segundo a historiadora Annie Suquet (2008), como já mencionamos no capítulo dois desta dissertação, Laban nos traz a noção da assinatura corporal. De acordo com a autora, Laban estabelece uma relação com o peso, a gravidade e a verticalidade que nasce da atitude interior do individuo, e essa atitude interior determina as qualidades que serão expressas no movimento. Podemos relacionar diretamente essa atitude interior com a noção de esforço que fundamenta um dos princípios do Sistema de movimento Laban, esclarecido mais detalhadamente no capítulo dois desta dissertação. Dessa forma, através do esforço, modulamos nossos gestos e nossa expressividade e vamos construindo uma assinatura corporal.

As modulações da transferência de peso definem, então, o ritmo dos movimentos, mas também seu estilo. São elas, enfim, que conferem a cada indivíduo, desde a primeira infância, a sua "assinatura corporal", a configuração cinética de seus gestos. (SUQUET, 2008, p. 528)

Podemos relacionar esse processo com a possibilidade de cada corpo já trazer consigo uma biografia particular escrita através dos movimentos e gestos que realiza. Estes gestos podem ser trabalhados e desenvolvidos como linguagem. Nessa direção, nos aproximamos da noção defendida por Pereira (2011) sobre memórias inscritas nos corpos. Conforme a autora, a partir de definição de Aristóteles sobre memória como fruto da imagem ${ }^{71}$, o corpo do

\footnotetext{
71 "Para Aristóteles, a memória é fruto da imagem. Fruto que, segundo ele, é ampliado pela reflexão e leva aos acontecimentos do passado que poderemos denominar de lembrança, recordação, memória. Sendo assim esta MEMÓRIA auxiliará o homem contemporâneo a reconhecer fatos que aconteceram no passado, recuperando situações pessoais vividas ou históricas que através do imaginário viabilizará uma possível verbalização e até quem sabe uma representação cênica". (PEREIRA, 2006, p. 1)
} 
intérprete seria permeado por memórias que podem ser imaginadas, verbalizadas ou levadas à cena por meio de gestos. Cada corpo cênico contém em si um somatório de experiências pessoais e poéticas que fazem parte das vivências particulares de cada pessoa e que podem se refletir em cena, por exemplo, através de estruturações coreográficas:

Na composição da cena é comum percebemos memórias inscritas
nos corpos que são de autoria do ator-autor, mas poderiam ser
também de autoria de vários outros narradores, fazendo com que a
partitura que chega na cena refinada, possa refletir um somatório de
experiências pessoais, vivências, diferentes técnicas e linguagens de
movimento; e estas experiências poderão sempre vir a ser
revigoradas por novas possibilidades poéticas. (PEREIRA, 2011, p. 6)

Baseados nessa noção de Pereira (2011) sobre memórias inscritas nos corpos, podemos relacionar esta com a assinatura corporal de Laban, pois, assim como em Laban (1978), para a autora essas memórias advêm de impulsos internos, de um esforço, um desejo individual, e chegam à cena através dos movimentos e gestos corporais. As memórias são acessadas por impulsos internos que geram ações e se concretizam no tempo/espaço da cena. É no corpo do intérprete que esse processo acontece.

As memórias que acompanham as ações que percebemos na cena, realizadas pelos atores sociais, são acessadas normalmente, através de impulsos interiores, associados a uma vontade de realização de um determinado procedimento que se concretiza no tempo presente, e que será acessado e consumido a cada nova realização seja um exercício, ensaio, ou alguma performance. O corpo é o espaço da memória do intérprete, lugar onde os sentidos se fundem perante o público e onde as ações compõem sua linguagem histórica e ideológica. (PEREIRA, 2011, p. 4-5).

No caso de nosso processo, os gestos e movimentos que retornavam podem ser vistos como memórias inscritas em nossos corpos que continham, no esforço, nos impulsos internos gerados por cada sequência coreográfica, parte das experiências e biografias particulares de cada uma das atrizesbailarinas. Através desses gestos que retornavam à cena como nosso somatório de vivências pessoais e poéticas é que nos foi possível conferir certa unidade às composições das células coreográficas que estávamos criando, construindo uma harmonia nas composições e na linguagem cênica proposta. Ao final deste trabalho, obtivemos um total de doze células coreográficas, que foram utilizadas na criação de nosso roteiro cênico. 
As impressões deste primeiro trajeto de nosso percurso criativo, se fizeram presentes na medida em que fomos realizando, durante a criação das células coreográficas, operações sensíveis e intuitivas que nos guiaram nesse primeiro momento e que continuaram a nos guiar ao longo de todo nosso percurso. Tivemos como objetivo configurar a nossa matéria-prima, o corpo, na elaboração de uma linguagem poética fundamentada em nossas experiências particulares e em nossa própria assinatura corporal.

(...) o ato criador como um contínuo processo de formalizar a matériaprima, com um determinado significado e de uma determinada maneira, no âmbito de um projeto estético e ético. Uma ação sensível e intelectual. Um processo que tende para a concretização desse grande projeto do artista e cujo produto é permanentemente experienciado e avaliado pelo artista e, um dia, por outros receptores. (SALLES, 2011, p. 91)

\subsection{Segundo trajeto: organização das células coreográficas para um roteiro cênico}

Seguindo nossa jornada na busca pela criação poética a partir de nossa matéria-prima (o corpo), partimos para nosso segundo trajeto: a organização das células coreográficas em um roteiro cênico que pudesse ser apresentado para o público. Deste modo, prosseguimos com nossa rotina de trabalho, na qual ensaiávamos e depois filmávamos, tendo acesso ao material que era produzido em cada encontro.

Nesse processo, o foco do trabalho foi a criação do roteiro cênico e esse processo exigiu criatividade, sensibilidade e intuição para que as possibilidades poéticas surgissem e fossem acessadas e processadas por nós, assim como os insights mencionados no tópico 4.1 desta dissertação. Neste percurso, seguimos o trabalho através das combinações entre as doze células coreográficas, que foram sendo ordenadas de forma consciente e precisa e, também, intuitiva, ou seja, ao combinar cada célula, fomos seguindo ideias sobre o espaço, o tempo e o peso, mas também nossa intuição, que muitas vezes nos guiou na elaboração das ideias e dos insghts, bem como na concepção do roteiro.

Assim, novamente se fizeram necessários certos recortes no material que possuíamos, como cortes ou modificações nas células coreográficas originais, para que pudessem ser relacionadas umas com as outras na 
elaboração do roteiro cênico. Nesse processo, foi inevitável adaptar as células na hora da criação, modificando pequenos movimentos e criando outros que serviram como ligação entre uma coreografia e outra.

Percebemos que o nosso material, as células coreográficas, ainda possuía muitas das características presentes nas sequências individuais, como a fragmentação dos movimentos, ritmo constante entre um movimento e outro (no sentido de terminar um para começar o outro), e certa fluência que destoava entre uma e outra célula. Para a criação do roteiro, foi essencial modificar esses aspectos, deixando que a forma dos movimentos fosse mais fluida, sem delimitar tão claramente quando uma célula começava e outra terminava, com o intuito de realizar cada movimento com precisão (início, meio e fim), mas sem ser fragmentado e dividido. Para este trabalho, foi necessário encontrar um fluxo de movimento em comum entre cada célula coreográfica que preenchesse todos os movimentos, de forma a ligar as células umas às outras no mesmo roteiro cênico, um fluxo que apresentasse as qualidades físicas experienciadas nos Laboratórios de Criação sobre o Sistema Laban e a pedagogia de Lecoq, bem como nuances de tempo, peso e espaço, de modo que os movimentos realizassem desenhos no espaço com distintos tempos e ritmos, mas que apresentassem coerência no resultado final, no roteiro como um todo.

Nesse aspecto, realizamos uma constatação relevante no que se refere à execução dos movimentos como material de estudo (Laboratórios de Criação) e como roteiro cênico que faz parte de uma criação com objetivo artístico e poético. $\mathrm{Na}$ execução das 45 sequências de movimentos, realizamos a movimentação com o objetivo de estudar cada fator, espaço, peso, tempo e fluxo, então os movimentos eram realizados de forma mais dividida e fragmentada para que compreendêssemos cada elemento estudado. Já na elaboração criativa do roteiro, a intenção foi realizar ligações poéticas, o que exigiu, além da precisão (espaço e tempo), a criação de um fluxo em que cada movimento fosse parte de uma composição harmônica, na qual as imagens e as sensações corporais pudessem ser percebidas e transmitidas. Desta forma, na composição do roteiro, as células 
coreográficas adquiriram outras dinâmicas corporais e imagens poéticas ${ }^{72}$ que tinham origem na sensação corporal das sequências, mas se modificaram na medida em que se relacionaram com o roteiro como um todo.

Essas diferenças sutis foram constatadas a partir de nossa percepção interna durante a execução dos movimentos como coreografia, pois percebemos que as sequências individuais foram um estudo de movimento que se transformou ao longo das composições. Logo, para a criação do roteiro, as sequências se modificaram no que se refere à sua plasticidade corporal (espaço e tempo) e quanto à nossa intenção e sensação durante a realização de cada movimento. Desse modo, ao modificar a nossa intenção durante a execução dos movimentos, que em nosso caso passou de um estudo para uma composição do roteiro coreográfico, influenciamos e transformamos as qualidades físicas e expressivas dos movimentos. Segundo Ostrower (2013), é a intenção, relacionada à nossa imaginação e ao nosso agir físico, que são indispensáveis para o ato criador.

O ato criador não nos parece existir antes ou fora do ato intencional, nem haveria condições, fora da intencionalidade, de se avaliar situações novas ou buscar novas coerências. Em toda a criação humana, no entanto, revelam-se certos critérios que foram elaborados pelo individuo através de escolhas e de alternativas. (OSTROWER, 2013, p. 11)

Através de nossa sensibilidade e intenção, realizamos nossas escolhas estéticas e poéticas na elaboração do roteiro. Porém, este processo se mostrou um trabalho árduo que não se encerrou com a finalização do roteiro cênico, o qual tinha um prazo determinado em virtude de fazer parte de uma pesquisa de mestrado. Logo, percebemos que a intenção é um aspecto que pode ser continuamente exercitado e trabalhado, pois cada movimento é composto por qualidades que podem variar de acordo com as dinâmicas, as tensões e os ritmos que imprimimos neles. Assim, ao alterar nossa intenção na execução dos movimentos, modificamos os seus fluxos e suas possibilidades espaciais, temporais e sensoriais, que podem ser transformadas e lapidadas em contínuo

\footnotetext{
${ }^{72}$ Este termo, imagens poéticas, se refere aos capítulos dois e três desta dissertação e se relaciona com imagens que utilizamos em nosso procedimento de trabalho, tanto no processo de improvisação corporal dentro do Sistema Laban como na pedagogia de Lecoq. Durante a improvisação, nos referimos a imagens poéticas, imaginárias e sensoriais como a cinesfera e o plano da porta, da roda e da mesa, em Laban. E as imagens sobre os elementos da natureza em Lecoq, como água, terra, fogo, chuva, vento, folhas, mar, entre outras que auxiliaram e estimularam o processo de criação corporal.
} 
processo de criação. Como nos fala Salles (2011), em permanente inacabamento.

O combate do artista com a matéria-prima nessa perseguição que escapa à expressão é uma procura pela exatidão e precisão em um processo de contínuo crescimento. $O$ artista lida com sua obra em estado de permanente inacabamento. (...) $\mathrm{O}$ artista dedica-se à construção de um objeto que, para ser entregue ao público, precisa ter feições que lhe agradem, mas que se revela sempre incompleto. O objeto "acabado" pertence, portanto, a um processo inacabado. (SALLES 2011, p. 84)

Contudo, nesse processo em contínuo inacabamento, fomos percorrendo certos trajetos que se tornaram fundamentais e aos quais podemos retornar quando necessário. Em nosso caso, retomamos o trabalho das imagens poéticas realizado durante a criação das sequências de movimento nos Laboratórios de Criação (imagens como a cinesfera em Laban e os elementos da natureza em Lecoq $^{73}$ ), pois estes foram recursos que auxiliaram tanto na criação das células coreográficas como na elaboração do roteiro.

Por exemplo, o uso da imagem da cinesfera influenciou na criação das células coreográficas, pois acessamos essa imagem com o objetivo de imaginar uma grande circunferência ao redor do corpo. Essa visualização colaborou para que nossos movimentos ficassem mais precisos no espaço, pois facilitou o acesso à conscientização física/espacial durante o deslocamento do corpo dentro das células coreográficas.

Além da cinesfera, outras imagens (planos da mesa, porta e roda ${ }^{74}$ ) nos auxiliaram no aperfeiçoamento de nossos movimentos no que se refere aos fatores espaço, tempo e peso e também a aspectos sensíveis e poéticos, como as imagens dos elementos da natureza água, terra, ar e fogo. No caso das imagens da natureza, sua presença foi tão forte que optamos por concretizar esses elementos em cena utilizando objetos como galhos secos, água, machado e cinzas, ${ }^{75}$ que se relacionaram com a nossa movimentação e colaboraram para a criação das atmosferas das cenas.

\footnotetext{
${ }^{73}$ Esse processo encontra-se expostos nos capítulos dois e três desta dissertação.

${ }^{74}$ A definição tanto de cinesfera quanto dos planos mesa, roda e porta, presentes no Sistema de Rudolf Von Laban, encontra-se descrita no capítulo dois desta dissertação.

${ }^{75} \mathrm{O}$ processo sobre a utilização de objetos cênicos está exposto no tópico 4.3 deste capítulo.
} 
Aqui, novamente percebemos nas noções de Pereira (2011) sobre memórias inscritas nos corpos uma relação direta com a criação do roteiro, pois foi através da sua elaboração que resgatamos as imagens advindas de nossas sensações e percepções corporais, que foram as imagens poéticas utilizadas na configuração das sequências de movimento. Ao acessar essas imagens fruto de nossas memórias corporais, foi possível gerar uma harmonia na composição do roteiro, pois através delas encontramos no fluxo dos gestos e das ações uma memória palpável que tornou possível a elaboração de um roteiro cênico fundado na poesia dos gestos de cada atriz-bailarina:

É no "palco" da memória que acontecerá a intersecção das ideias, dos sentimentos, das subjetividades investigadas, espaço de inesperadas revelações. Composta por diferentes emoções, de diferentes períodos, perpassando por toda essência do intérprete, a memória das ações chegará até a "superfície" da carne, parecendo uma matéria palpável, possibilitando uma quase reinvenção das próprias recordações. (PEREIRA, 2011, p. 5).

Sendo assim, percebemos que as imagens poéticas funcionaram como guias que nos conduziram e concentraram na hora da execução cênica. Elas auxiliaram tanto no desenho e plasticidade corporal quanto na sensação do movimento. Ao recorrer a elas no momento da criação, nos sentimos mais seguras para elaborar o roteiro, pois a partir das imagens poéticas o roteiro seguiu uma lógica própria baseada na fisicalidade singular de cada uma das intérpretes. É possível relacionar esse aspecto com a ideia de Ostrower (2013) sobre imagens referenciais, imagens elaboradas a partir de nossa percepção e intuição e que se tornam referências em nossos processos criativos.

As imagens referenciais não são herdadas. Não são estereótipos de
percepção, não são conceitos. Formam-se, basicamente, de modo
intuitivo. Configurando-se em cada pessoa a partir de sua própria
experiência e como "disposição característica" dos fenômenos, isto é,
como imagem qualificada pela cultura, sua visão é ao mesmo tempo
pessoal e cultural. (...) As imagens referenciais são, portanto,
ordenações internalizadas. (OSTROWER, 2013, p. 60)

A partir de nossa experiência e nossas imagens referenciais, construímos nossas ordenações internas (Ostrower, 2013) através da ligação entre as células coreográficas, tanto nos aspetos plásticos e cinéticos do movimento (espaço, peso e tempo) quanto imaginários e intuitivos (a utilização das imagens poéticas), e fomos ordenando esse material em um roteiro cênico. 
Durante o processo de elaboração do roteiro, experimentamos diferentes combinações coreográficas e testamos objetos cênicos, músicas com sons de natureza, bem como figurinos. Nesse percurso, algumas escolhas foram feitas e dificuldades foram encontradas e apontadas em muitos momentos de orientação com a Profa. Dra. Sayonara Pereira ${ }^{76}$, que nos mostrou, entre outros aspectos relevantes, nossa dificuldade em relação à precisão da utilização dos fatores tempo e fluência na execução dos movimentos e a possibilidade de sinalizar certas sensações corporais através das palavras, do emprego de poemas nas cenas. Além disso, Pereira sugeriu que fosse desenvolvida uma trilha sonora para ser executada e realizada de acordo com as nossas composições coreográficas, pois as músicas de $C D$ que testamos não se encaixavam nas movimentações criadas, que apresentavam um ritmo próprio, uma música particular que deveria ser respeitada. Como nos propõe Pereira (2011), uma musicalidade singular que pode ser utilizada como ligação entre os movimentos no roteiro como um todo:

Alguns diretores acreditam que a partitura de movimento cênico está correta, na sua essência, quando mesmo, sem uma música externa específica, esta partitura já possui sua própria musicalidade. $O$ fator tempo pode ser ainda considerado um agente que realiza a "costura" individual de cada ação, dentro das partituras de movimentos, e que serão ligadas a um todo. (PEREIRA, 2011, p. 5).

Desse modo, após as orientações de Pereira, realizamos uma pesquisa com o propósito de encontrar sons, músicas e poemas que pudessem dialogar com o nosso trabalho corporal e com os elementos da natureza. Esse processo encontra-se exposto no próximo tópico deste capítulo, 4.3.

Então, ao longo desse segundo trajeto, elaboramos o roteiro cênico, que se configurou, posteriormente, em nosso exercício cênico de composição. O roteiro foi construído a partir das doze células coreográficas, das imagens poéticas, das modulações entre aspectos plásticos do movimento, como espaço, tempo, peso e fluência, da utilização de objetos relacionados a elementos da natureza e da nossa intenção e intuição.

\footnotetext{
${ }^{76}$ Sayonara Pereira, orientadora desta pesquisa de mestrado, é professora efetiva, e pesquisadora da Escola de Comunicações e Artes da Universidade de São Paulo e diretora do LAPETT (Laboratório de Pesquisa e Estudos em Tanz Theatralidades) (CAC/ECA/ USP).
} 
Nesse processo foi essencial encontrar a precisão (início, meio e fim) dos movimentos, suas diferentes tensões e densidades, que precisaram ser delimitados quanto a suas qualidades e dinâmicas. Ensaiamos o roteiro muitas vezes até que os movimentos estivessem em nossos corpos e as imagens que criamos pudessem transparecer e se fazer presentes. Assim, ao ensaiar o roteiro coreográfico, foi necessário exercitar a presença das imagens poéticas através de nossa movimentação corporal, como se o corpo fosse um "espelho" no qual as imagens são refletidas na forma externa de nossa movimentação e de nossos gestos. Porém, este trabalho sobre as imagens poéticas se tornou um aspecto complexo e se mostrou como um processo inacabado, o qual teremos que seguir pesquisando e aperfeiçoando para além da investigação que se encerra nesta pesquisa de mestrado.

Assim, o nosso roteiro se configurou em treze cenas que foram dividas em dois momentos. Segue uma versão do roteiro contendo o número e o título de cada cena:

$1^{\circ}$ Momento: cenas um até sete.

Legenda: Nesse roteiro, a letra K significa Kalisy e a letra S significa Sissi.

1. Prólogo do oito: deslocamento em desenho de oito no chão.

2. Sequência dos galhos: caminhada em postura de quatro apoios com galhos nas costas, ao final posiciona os galhos na diagonal do palco.

3. Célula de movimento da mão como flor acima da cabeça: finalizar com ninar com a mão e com uma poesia.

4. Mãos dadas como babuskas: termina com S. rodando pelo espaço.

5. Movimentação do vento: até o encontro no centro do palco onde forma-se a imagem de "Shiva".

6. "Costura" entre cenas o poema e o jarro de água: S. se desloca para o fundo e fala um poema, e K. entra carregando um jarro com água, que posiciona no fundo do palco.

7. Sequência da água: termina com o gesto de flor na mão.

Transição para segundo momento: K. pega o jarro de água vai até $S$., fala um poema e derrama a água em S. Finaliza soprando o jarro de água vazio. $\mathrm{S}$. levanta e torce o vestido molhado, vai até a parede e puxa um fio de nylon preso ao teto, que contém uma garrafa de água que permanece pingando sobre o local onde $\mathrm{S}$. foi molhada e ela posiciona um tronco de árvore no lugar dos galhos. K. arruma os galhos em forma de asas de anjo no fundo do palco e se posiciona 
para começar o segundo momento do roteiro. S. sopra um punhado de cinzas sobre $\mathrm{K}$.

$2^{\circ}$ Momento: cenas oito até oito até treze

8. Sequência do fogo: finaliza indo para o fundo com movimentos de cavar a terra.

9. "Costura" entre as cenas o machado: no final do fogo entra S. com um machado e dá uma machadada no tronco de árvore e deixa o machado cravado no tronco.

10. Sequência da terra: Finaliza com S. no chão e K. se desloca para os galhos no fundo do palco, formando uma imagem como asas de anjo.

11. Célula coreográfica do carregamento através do cabelo: termina com sequência dos passarinhos esfregando as mãos. K. vai até os galhos e pega uma carta e leva até o tronco onde está o machado.

12. Sequências saltos nas laterais: deslocamento na diagonal, até que S. e K. fazem uma longa pausa na diagonal.

13. Sequência da carta e do tronco: $\mathrm{S}$. vai até o tronco, abre a carta, lê um poema e sai andando em quatro apoios carregando a carta nas costas. K. vai até o tronco de árvore, pega o machado, dá sete machadadas no tronco e, na sétima, todas as luzes se apagam. Fim.

Esta foi uma das versões do roteiro, que posteriormente sofreu pequenas modificações em virtude do acréscimo de alguns sons e algumas interferências sonoras durante a execução da trilha, explicadas no próximo tópico deste capítulo. Este pretende ser um roteiro guia de nosso exercício cênico. As cenas aparecem aqui pelo título que receberam e na ordem em que foram executadas. Utilizamos títulos que facilitassem o nosso acesso às imagens que cada cena propunha, enfatizando o enfoque do trabalho sobre as imagens poéticas como guias na elaboração do roteiro. Em anexo a esta dissertação encontra-se o DVD, no qual está registrada a apresentação do exercício cênico de composição, que contém o roteiro na íntegra. É possível, também, acessar um pequeno vídeo com alguns trechos da apresentação do exercício cênico através do seguinte link na internet: https://vimeo.com/79368998.

Ao finalizar a criação do roteiro, realizamos algumas considerações relevantes sobre o nosso trajeto investigativo/criativo através da elaboração do roteiro, que teve por objetivo realizar uma comunicação por meio da linguagem corporal poética. Foi possível constatar que o trabalho de criação assumiu uma 
forma estética e específica quando as células coreográficas foram estruturadas em nosso roteiro cênico, gerando assim as cenas que possuíam uma ordenação e uma lógica próprias. Segundo Ostrower (2013), é por meio da ordenação que conseguimos encontrar nossa expressão; através da forma ordenamos nossa expressão subjetiva de maneira objetiva. Essas formas, segundo ela, são formas simbólicas:

\begin{abstract}
Formas simbólicas são configurações de uma matéria física ou psíquica em que se encontram articulados aspectos espaciais e temporais. As figuras de espaço/tempo são percebidas como um DESENVOLVIMENTO FORMAL que contém sequências rítmicas, proporções, distanciamentos, aproximações, indicações direcionais, tensões, velocidades, intervalos, pausas. É em termos espaciais e temporais, ou seja, em termos de um movimento interior, que avaliamos a percepção de nós mesmos e nossa experiência do viver - não há outro modo de configurá-las em nós e trazê-las ao nosso consciente. Por isto, as categorias de espaço e tempo são indispensáveis para a simbolização. (OSTROWER, 2013, p. 25, grifos da autora)
\end{abstract}

Podemos dizer que o roteiro cênico que desenvolvemos para $O$ Sentido Se Sente com o Corpo se configurou como uma forma simbólica, pois ordenamos as células coreográficas que criamos segundo os aspectos espaciais e temporais e no que se refere às nossas sensações (imagens poéticas). Logo, foi a partir de nossa percepção interna que elaboramos 0 roteiro como uma ordenação lógica baseada em nossas movimentações e sensações corporais.

Nesse momento, se faz relevante retomarmos a noção de fisicalidade, como trazida pelo crítico português António Pinto Ribeiro (1994) no capítulo um desta dissertação. Como nos diz Ribeiro (1994), no teatro do $\operatorname{corpo}^{77}$ é a fisicalidade que substitui a narrativa: "A fisicalidade como fenômeno, ora alternativo ora convivente com a narratividade, impôs-se sobre as fronteiras dos gêneros" (RIBEIRO, 1994, p. 13). Segundo o crítico, é na fisicalidade presente tanto em encenações de dança como em um teatro do corpo, que predomina a elaboração de uma narrativa fundamentada nos movimentos e gestos dos atoresbailarinos, uma narrativa que se desenvolve através e por entre os gestos e a fisicalidade singular de cada intérprete.

\footnotetext{
${ }^{77}$ Essas noções estão expostas e esclarecidas no capítulo um desta dissertação.
} 
Sendo assim, relacionamos o processo de criação do nosso roteiro cênico com a noção de fisicalidade de Ribeiro (1994), pois elaboramos o roteiro e fomos nos apropriando dele através de nossas composições coreográficas, que estavam fundamentadas nos gestos e movimentos particulares que cada atriz-bailarina vinha desenvolvendo e criando. Através desta fisicalidade nos foi possível desenvolver o roteiro cênico e elaborar uma linguagem artística fundamentada no corpo cênico de cada intérprete e nas escolhas estéticas e poéticas que realizamos ao longo deste trajeto. Aqui também se faz relevante trazer a noção de Pereira (2011) sobre memórias inscritas no corpo, já que foi por meio de nossas memórias, presentes nas imagens poéticas de nossos gestos e composições coreográficas, que organizamos o roteiro cênico de acordo com nossas necessidades e escolhas artísticas e estéticas.

As memórias trazidas à cena não são apenas de autoria do coreógrafo da peça, mas também de autoria dos vários narradores, que são os intérpretes-bailarinos que trazem para o texto coreográfico um somatório de experiências pessoais (...) (PEREIRA, 2006, p. 1).

Através desse somatório de experiências pessoais, o intérprete vai imprimindo sua personalidade nas composições das cenas e no texto coreográfico que vai se constituindo como narrativa a partir da fisicalidade singular presente nos gestos e movimentos de cada ator-bailarino em cena.

Essa personalidade, essa fisicalidade singular, nasce da percepção sutil de nossos corpos e, por consequência, dos impulsos internos que geram os gestos e movimentos de cada intérprete em cena. Esse movimento interior vem ao encontro do que já nos foi dito por Laban sobre seu esforço. ${ }^{78}$ Segundo ele, todo movimento nasce de um esforço interior. Como refletimos no primeiro tópico deste capítulo, é ao nos conscientizarmos de nosso esforço, nossa atitude interior, que configuramos o que Laban denomina como assinatura corporal.

Nossa pesquisa vem ao encontro dessas noções, pois pretende, através do discurso corporal estabelecido (roteiro cênico), desenvolver uma linguagem poética fundada na assinatura corporal de cada atriz-bailarina. Ao nos referirmos ao termo assinatura corporal, podemos falar, como nos diz Pereira

\footnotetext{
${ }^{78}$ Esta noção sobre esforço encontra-se no capítulo dois desta dissertação.
} 
(2013), em uma caligrafia pessoal ${ }^{79}$ que é escrita através dos gestos e movimentos de cada ator-bailarino. Ao longo de nosso percurso criativo, buscamos desenvolver nossas caligrafias pessoais e realizamos um passo nessa direção com a elaboração da investigação desenvolvida nesta dissertação de mestrado. Pretendemos, assim, dar continuidade a esse processo, pois este é um trabalho em permanente desenvolvimento na vida do artista do corpo.

Desta forma, os termos assinatura corporal e caligrafia pessoal, que nascem da nossa conscientização e percepção sobre nosso movimento interno (esforço) e brotam como fluxos de gestos cênicos espaciais e temporais, nos remetem à noção de gramática semântica proposta por Gil (2004):

\begin{abstract}
Assim, e num sentido muito diferente do da linguagem falada, deve conceder-se ao movimento dançado o poder de combinar unidades variáveis (nem fixas, nem discretas) em sequências dotadas de sentido, seja qual for a modalidade de sentido considerada. (...) Empreguemos, ainda que provisoriamente, a expressão de "gramática semântica" para caracterizar a lógica própria que rege o movimento dançado (e toda a coreografia). Gramática paradoxal: nem os signos nem as regras são dados de antemão, porque só o movimento constrói (exceto danças muito codificadas). As sequências dançadas não se organizam segundo regras de disposição dos signos, mas segundo circuitos de energia que regulam a formação do sentido. (GIL, 2004, p. 82)
\end{abstract}

Sendo assim, a partir de nossa conscientização sobre o fluxo de energia que rege nosso movimento interno, nossa atitude interior, podemos construir e ordenar formas simbólicas (em nosso caso, o roteiro cênico) dotadas de sentido. Salientamos que esta é uma operação complexa e que exige um trabalho árduo de práxis, concentração e conscientização, contudo acreditamos ter esboçado algo nessa direção ao ordenar os fluxos de movimento em células coreográficas que deram origem a nosso roteiro cênico fundamentado na fisicalidade singular de cada atriz-bailarina. Seguindo em nosso processo, fomos intensificando esse roteiro corpóreo a partir de outras camadas de organização de sentido, que foram a poesia textual, a textura sonora e a iluminação, tópicos que são explicados a seguir.

\footnotetext{
${ }^{79}$ Pereira, em encontro de orientação, setembro de 2013.
} 


\subsection{Terceiro trajeto: relação entre as diferentes camadas: o roteiro cênico, a poesia textual, a textura sonora e a iluminação}

Ao finalizarmos a criação do roteiro cênico, foi possível visualizar o caminho que havíamos percorrido até então: criação das sequências individuais de movimentos (45 sequências), estruturação de células coreográficas resultantes da combinação entre as sequências individuais (12 células) e elaboração do roteiro cênico a partir das células coreográficas (13 cenas).

Assim, seguimos nosso percurso investigativo na criação do exercício cênico e realizamos um trabalho de composição sobre os elementos cênicos que contribuíram muito para a concretização de nosso exercício O Sentido se Sente com o Corpo. Foram eles: textos poéticos, textura sonora, figurino, objetos e iluminação.

No que se refere aos figurinos, já havíamos realizado alguns testes durante a elaboração do roteiro cênico e optamos por utilizar vestidos soltos no corpo e de tecido leve, que colaboraram para a execução dos movimentos e enfatizaram a presença das figuras femininas, as atrizes-bailarinas ${ }^{80}$ em cena e sua relação com os elementos da natureza. Os vestidos que escolhemos foram o modelo de alça no ombro com caimento até perto do tornozelo e na cor bege, como pode ser observado nas fotografias de cena a seguir.

Figura 28 - Atrizes-bailarinas: Sissi Betina Venturin e Kalisy Cabeda.

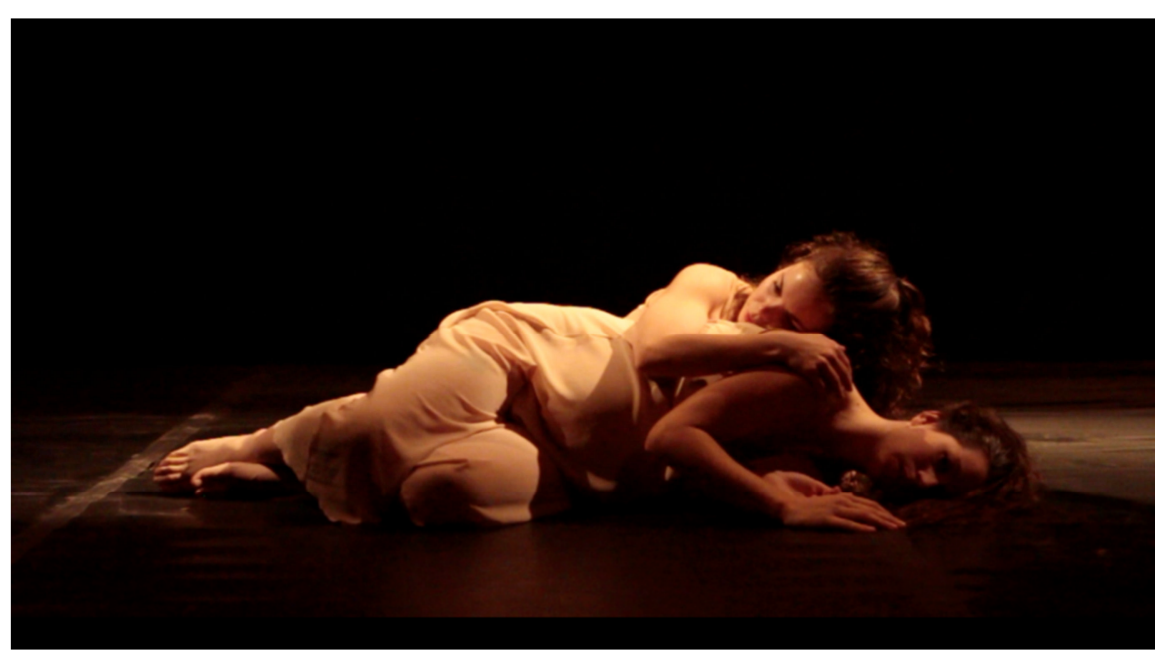

Foto: Rafael Avancini

\footnotetext{
${ }^{80}$ Desde início de nossa pesquisa, contamos com a presença da pesquisadora desta dissertação e uma pesquisadora voluntária, Sissi Betina Venturin, como já exposto no capítulo dois desta dissertação.
} 
Figura 29 - Atrizes-bailarinas: Sissi Betina Venturin e Kalisy Cabeda.



Foto: Rafael Avancini.

Quanto aos objetos cênicos, também realizamos testes durante a criação do roteiro e optamos por objetos que fossem ligados aos elementos da natureza, como o fogo, a água e a madeira. Assim, em algumas "costuras" entre uma e outra célula coreográfica, utilizamos elementos que se relacionaram com a nossa movimentação e colaboraram para a criação das atmosferas das cenas. Nesse percurso, agregamos alguns objetos que fizeram parte de nosso exercício cênico. Foram eles: galhos secos, pedaço de tronco de árvore, papel, jarro com água, cinzas, vela, machado e concha do mar. Esses objetos cênicos foram importantes em algumas transições de cena, já que possuíam uma forma e materialidade precisas às quais colaboraram para tornar presentes as sensações internas (imagens poéticas) que guiaram nossas coreografias em alguns momentos. Esses objetos fizeram parte do exercício cênico também como objeto/cenário, pois estavam presentes desde início das cenas e acabaram se tornando nosso cenário, já que complementavam nosso palco (caixa preta italiana), que continha nossos corpos em movimento, o músico-sonoplasta e os objetos. Seguem fotografias de alguns objetos utilizados em cena. 
Figura 30 - Galhos utilizados em cena pelas atrizes-bailarinas: Sissi Betina Venturin e Kalisy Cabeda.

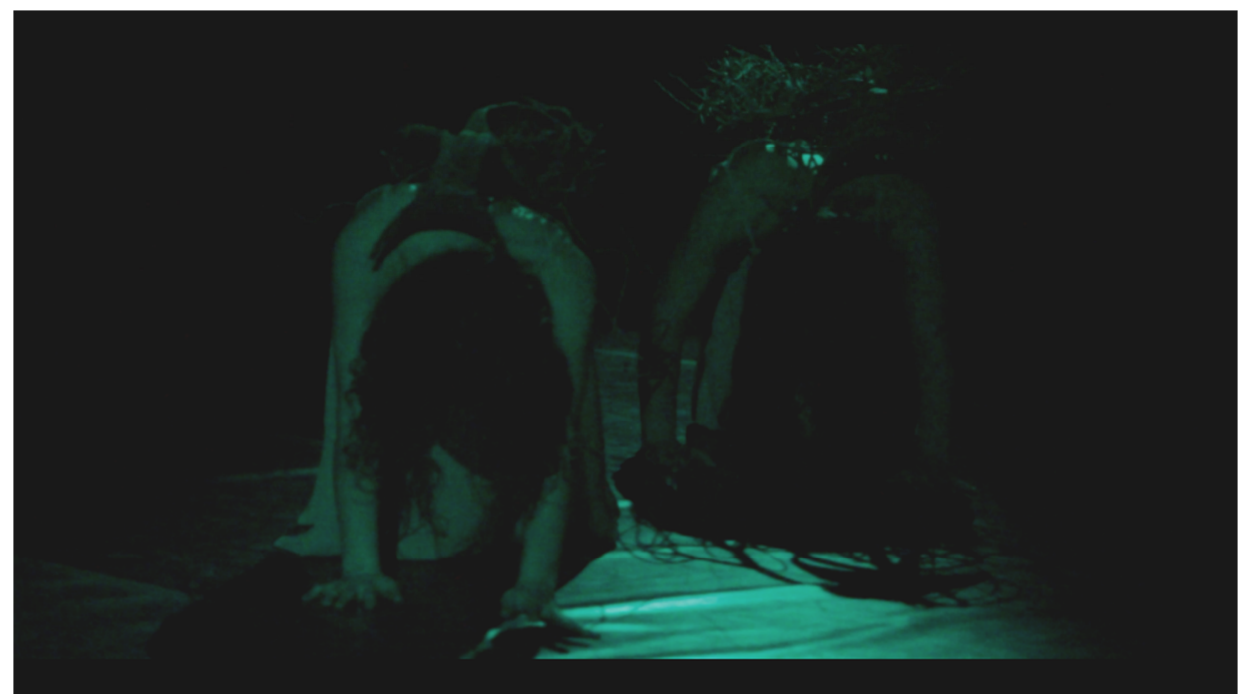

Foto: Rafael Avancini.

Figura 31 - Objetos utilizados em cena: machado e tronco.

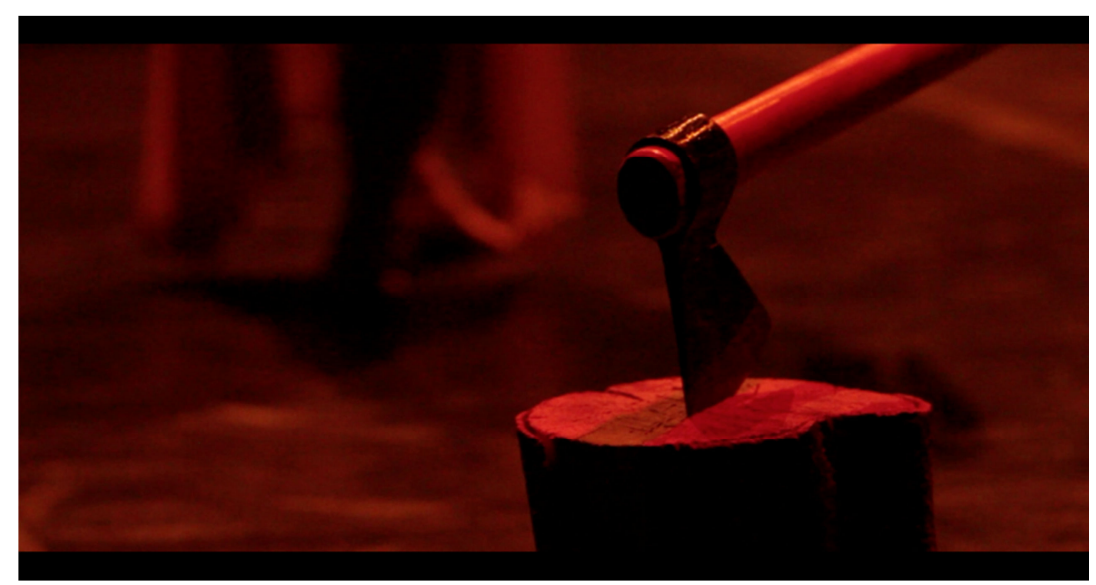

Foto: Rafael Avancini.

Com o intuito de sinalizar alguns momentos do roteiro, com textos que pudessem dialogar com o material que vínhamos trabalhando, ou seja, o corpo cênico como linguagem poética da cena e imagens dos elementos da natureza, realizamos uma breve pesquisa e encontramos nos livros de Josely Vianna Baptista, ${ }^{81}$ uma poesia que se relacionava diretamente com nossa investigação cênica.

81 Josely Vianna Baptista (1957) é uma poetisa, tradutora e escritora brasileira. Entre seus livros, estão: $\operatorname{Ar}$ (1991), Corpografia (1992), este em colaboração com o artista plástico Francisco Faria, $A$ concha das mil coisas maravilhosas do velho caramujo (2001), que, no ano seguinte, recebeu o VI Prémio Internacional Del Libro Ilustrado Infantil y Juvenil del Gobierno Del México. Em 1996, criou a 
Baptista é uma poetisa que aborda o corpo e a natureza de forma singular, interligando o corpo às imagens e sensações da natureza e trazendo a noção do "corpo como lugar de contemplação de paisagem" (BAPTISTA, 1992), na qual o corpo pode ser um espaço contemplativo tanto internamente (nossa própria percepção) como externamente (o olhar e a percepção do observador sobre o corpo). Todas essas características, presentes em obras como Corpografias (1992), Ar (1991) e Roça Barroca (2011), fizeram muito sentido para nosso processo de criação, que esteve fundamentado na configuração de uma linguagem baseada no potencial poético do corpo e nos elementos da natureza.

Assim, ao lermos suas poesias, nos identificamos em muitos aspetos e nos sentimos contempladas com suas palavras líricas sobre o corpo, o ser e a natureza, sendo que selecionamos alguns poemas com os quais nos identificamos quanto às imagens e metáforas poéticas que continham. Utilizamos três poemas que fizeram parte de nosso roteiro cênico nos momentos de "costuras" entre cenas e de um deles retiramos o nome de nosso exercício cênico, O Sentido se Sente com o Corpo, tamanha foi nossa afinidade com a essência de sua obra. Além dos poemas de Baptista, usamos também um provérbio de autoria de Buda Gautama. ${ }^{82}$ Seguem os poemas e o provérbio na íntegra.

\author{
Zen-Riders \\ O sentido se sente com o corpo, \\ como olho se molha quando chora. \\ O sentido é quente com o corpo, \\ como olho que brilha quando gosta. \\ O sentido se pensa com o corpo, que pressente \\ esse sentir que não mente. \\ O silêncio vai-se lendo em silêncio, \\ quando quase do avesso me convenço vai-se lendo. \\ Sentido no silêncio vai-se vendo, \\ do avesso me convenço. \\ O silêncio vai dizendo ao silêncio. (BAPTISTA, 1992, p. 34)
}

coleção Cadernos da Ameríndia, dedicada a temas do repertório cultural e textual de etnias indígenas sulamericanas.

82 Sidarta Gautama, popularmente conhecido como Buda, foi um príncipe da região do atual Nepal. A época de seu nascimento e de sua morte são incertos, acredita-se ser por volta de 563 a.C. a 483 a.C. Buda é a figura-chave do budismo: os budistas creem que os acontecimentos de sua vida, bem como seus discursos e aconselhamentos monásticos, foram preservados depois de sua morte e repassados para outros povos pelos seus seguidores. 
Que pulse, repulse sóis, tufos, violetas sob um céu pedrento de chuva ou de vento e traduza os fólios da imagem da pele em nuvem lazúli, bulbo de veludo e pulse, repulse sóis, tufos, lilases ao ler os infólios da imagem da pele em palimpsesto: um abrir-se à brasa quando a alma nua se veste de ares e o sol calcina em salamandras rubras a gala sem flor de uma orquídea rara. (BAPTISTA, 1992, p. 23)

Ñamandu, nosso primeiro, verdadeiro Pai,

Antes de ir desdobrando seu futuro céu,

Antes de ir desdobrando a primeira terra,

Já existia entre o sombrio vento sul

Esse vento primeiro em que Nosso Pai viveu

Sempre vem outra vez

No fim do inverno,

Antes que o inverno reviva seus renovos.

O inverno fenece,

O ipê floresce

Os ventos migram para o tempo novo

E vêm os ventos novos, a primavera,

A rediviva primavera. ${ }^{83}$ (BAPTISTA, 2011, p. 43)

Esta existencia es tan transitoria

Como las nubes del otoño

Mirar el nascimento y muerte de los seres

Es como mirar los movimentos de una dança

Una vida es un clarón y un

Relámpago en el cielo;

Corre como un torrento

De agua d'baja la montaña. ${ }^{84}$ (BUDA, Gaudama)

Durante o processo de relacionar os poemas com o nosso roteiro cênico, foi necessário perceber os momentos em que o texto poderia ser dito com a finalidade de colaborar com as imagens poéticas que os nossos corpos estavam propondo, bem como ampliar a percepção de nossos gestos e dos elementos visuais utilizados em cena. No momento de falar o poema em cena, o trabalho realizado com o músico-sonoplasta foi muito importante, pois ele contribuiu para nosso aperfeiçoamento textual na medida em que foi despertando nossa percepção e, por consequência, nossa voz, para a compreensão do texto como música, o texto como parte do nosso corpo e da nossa sonoridade.

Seguindo neste aspecto sobre música e som, nosso objetivo foi elaborar uma trilha sonora que pudesse contemplar a musicalidade presente em nossas

\footnotetext{
83 Trecho retirado da tradução para o português do mito cosmogônico da tribo indígena Mbyá-Guarani, realizada por Josely Vianna Baptista em edição bilíngue (guarani-português), em 2011.

84 Provérbio de Buda Gautama. "Esta existência é transitória, como as nuvens de outono. Ver o nascimento e morte dos seres. É como ver os movimentos de uma dança. Uma vida é um clarão um relâmpago no céu. Corre como uma torrente de água de baixo da montanha." (tradução nossa).
} 
criações coreográficas e que remetesse a sons da natureza, como água, vento, galhos e sons de percussão. Uma música que acompanhasse nossos movimentos, com o intuito de complementar e colaborar para mudanças de ritmos e pausa, bem como no estabelecimento das atmosferas através dos elementos da natureza. Sendo assim, após alguns testes com músicas gravadas e das orientações de Pereira, decidimos encontrar um instrumentista que executasse a trilha ao vivo. Com grande alegria, conseguimos a parceria do músico e sonoplasta Jorge Peña, ${ }^{85}$ que criou e executou a textura sonora de nosso exercício cênico.

No caso da criação da trilha sonora, ou melhor, da textura sonora, como ele mesmo denominou, Penã foi muito sensível e presente. Observando nossos movimentos corporais e nossa relação com os elementos da natureza, ele foi colaborando com instrumentos que remetiam ora à atmosfera da cena e elementos da natureza, ora aos nossos movimentos corporais. Realizou uma escuta muito sincera conosco e amplificou as sensações físicas e imagéticas através de instrumentos com sons relacionados à natureza, como sansula, gongo, tambor, apitos e chocalhos, entre outros. Alguns desses instrumentos podem ser observados na fotografia a seguir.

\footnotetext{
85 Jorge Peña nasceu no Uruguai, é fotógrafo, músico, percussionista e sonoplasta. Iniciou sua carreira em 1977 em Montevideo, quando apresentou "Entre Pitos y Flautas", de Ricardo Fontana, e coreografias de Adriana Lagomarsino. Participou de uma turnê com Mercedes Sosa pelo Brasil em 1987. No teatro, integrou o Grupo Ornitorrinco e, até hoje, faz parte da Companhia de Teatro Pessoal do Faroeste, do diretor Paulo Faria.
} 
Figura 32 - Instrumentos de percussão e sopro utilizados em cena, da direita para a esquerda: harmônico, chocalho de palha, apitos de madeira, conduíte de metal, baquetas, tornozeleiras-chocalho de sementes, maracás e baquetas de zithar.

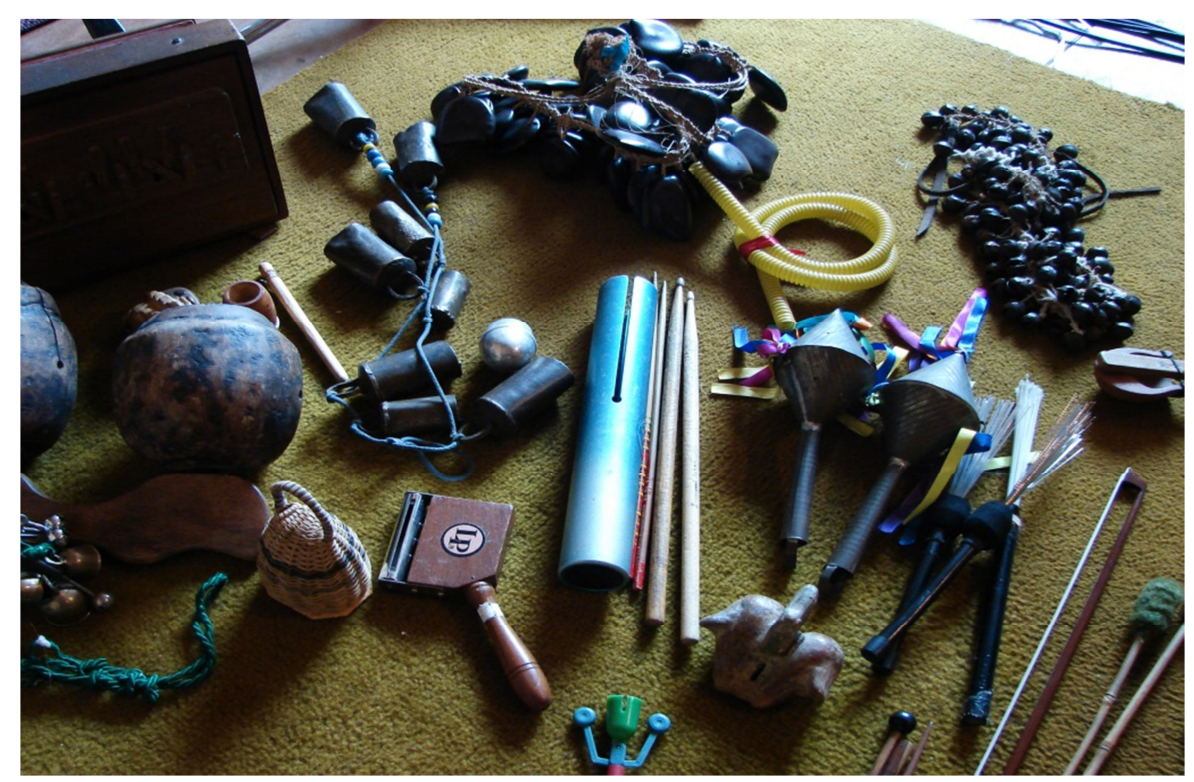

Foto: Jorge Peña.

A textura sonora foi criada em um diálogo sensível com nossos movimentos e sons, em harmonia com os corpos em cena e com os elementos fogo, ar, terra e água. Através de uma conversa entre corpo e som, fomos desvendo alguns mecanismos que nos permitiram compreender que o som também era movimento, assim poderíamos nos relacionar através de nossos movimentos corporais com os movimentos sonoros de Penã. Nesse percurso, fomos construindo a camada sonora do exercício cênico, que amplificou e intensificou nossas coreografias bem como nossa percepção sobre o fator tempo no exercício cênico como um todo. O som se tornou mais uma camada de composição de nosso trabalho, dialogando com os movimentos e criando também novas camadas de sentido para os corpos e as atmosferas das cenas. Segue um trecho da entrevista com Peña sobre nosso processo de trabalho:

Há muitos anos venho desenvolvendo meu trabalho com foco na natureza, elementos, dia, noite, ventos, silêncios. Tem muitos momentos que estes elementos estão bem definidos, mas também para meu trabalho das paisagens sonoras não deixo isto sempre claro, óbvio, misturo os momentos e coloco ventos juntos ao som do oceano ou um pássaro junto ao vento. Vou costurando com os elementos, mas não reforçando, não fazendo o óbvio e sim deixando aberta a imaginação do público para também complementar o espetáculo. (PEÑA, em entrevista sobre o processo de criação em fevereiro de 2014). ${ }^{86}$

\footnotetext{
${ }^{86}$ As entrevistas realizadas com a equipe de criação que participou do exercício cênico encontram-se no item Anexos desta dissertação.
} 
O trabalho realizado com os sons e criações musicais propostas pelo músico-sonoplasta trouxeram uma importante percepção de tempo e ritmo para toda a nossa movimentação corporal, influenciando o nosso tempo de execução a partir de um elemento externo ao corpo, o estímulo sonoro. Foi muito rica a experiência de criar junto com Peña, pois ele foi dialogando em cada parte, percebendo o que era apropriado e estabelecendo uma conexão direta entre movimento e som.

Último elemento cênico trabalhado, a iluminação foi criada e executada por um grande amigo e parceiro, o diretor de fotografia Di Pannacci. ${ }^{87}$ Ele esteve conosco na fase final do processo e realizou a criação e operação da luz nos dias de apresentação. Este elemento colaborou para o estabelecimento das atmosferas de cada cena, bem como para o detalhamento sobre a movimentação corporal no espaço. Além do diálogo entre a luz e os fluxos de movimentação, o iluminador baseou-se nos elementos da natureza para escolher as cores que fizeram parte de cada momento do exercício cênico. Assim como nosso roteiro, que foi dividido em dois momentos, ele dividiu as cores em duas paletas que foram do violeta ao verde e do amarelo ao vermelho. Nos momentos que os movimentos eram mais leves e se relacionavam com elementos como ar e água, ele usou as cores violeta, azul e verde. Já nos movimentos mais fortes e que se relacionavam com elementos como terra e fogo, ele usou as cores amarelo, laranja e vermelho. Segue o mapa de luz elaborado por Di Pannacci.

\footnotetext{
${ }^{87}$ Diretor de Fotografia Pós-Graduado na Escuela de Cine y Televisión de Madrid. Fotografou diversos curtametragens, entre eles, "En Mi Burbuja", filmado em $16 \mathrm{~mm}$, ganhador do prêmio de melhor fotografia no concurso "Kodak Film School Competition", na Espanha, no ano de 2011. Também fotografou o longametragem "Paisagens do conhecimento", exibido no Canal Brasil. Trabalhou como iluminador com o grupo de teatro Andaime em Piracicaba. Realiza trabalhos Audiovisuais com o "Coletivo Âmago".
} 
Figura 33 - Mapa de Luz do exercício cênico: O Sentido se Sente com o Corpo.

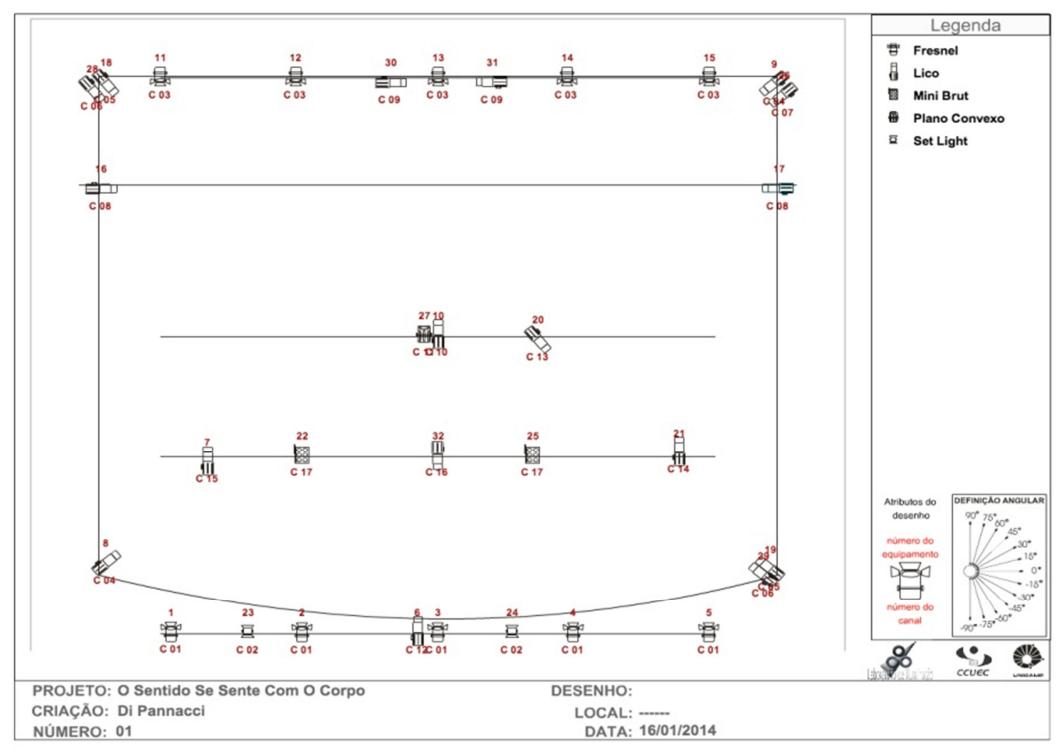

Fonte: elaborado por Di Pannacci.

Este foi um elemento cênico que tivemos pouco tempo para desenvolver, mas que foi essencial na criação das atmosferas das cenas e complementou o diálogo sensorial e estético estabelecido com a textura sonora.

\begin{abstract}
As texturas sonoras criadas pelo músico Jorge Peña colaboram maravilhosamente para a composição cênica. Assim como as forças das diferentes qualidades de movimento e formas da natureza que inspiraram as coreografias, o som é uma interferência direta e sensível, que influencia cada gesto, desde a emoção até o corpo. A iluminação foi um momento especial de criação conjunta, adentrando as camadas sutis das intenções das cenas e sua correspondência com as atmosferas geradas pelas cores e intensidades da luz. Estes ambientes sensoriais de som e luz permeiam o movimento e adicionam sentido às composições cênicas, atualizando os gestos e detalhes através do diálogo e sensação que geram. (VENTURIN, em entrevista sobre o processo de criação em fevereiro de 2014). ${ }^{88}$
\end{abstract}

Após o término do trabalho de criação, percebemos que as camadas entre corpo cênico, poesia, som e luz começavam a dialogar e se afinar, cada uma contribuindo para amplificar e intensificar as sensações e imagens poéticas das cenas. Porém, percebemos que ainda era preciso mais tempo de maturação para que o exercício cênico atingisse maior qualidade e sintonia entre os elementos, tempo do qual não dispúnhamos em virtude do prazo para

\footnotetext{
${ }^{88}$ Idem referência 23.
} 
a realização desta pesquisa de mestrado. Contudo, percebemos também que possuíamos um material cênico interessante e palpável, criado e elaborado com base na fisicalidade poética de cada atriz-bailarina e nas experiências sensoriais e intuitivas despertadas pela música, pela poesia textual e pela iluminação.

É relevante destacar que, apesar das fragilidades presentes no trabalho, todo o processo de criação do exercício cênico foi muito rico e intenso, pois todos os envolvidos estiverem muito presentes nessa experiência testando, colaborando e dialogando com criatividade, sinceridade e atenção uns com os outros em um exercício colaborativo de contínua troca de sensibilidades.

(...) os processos coletivos, como nos casos do cinema, do teatro, da dança e da música. São manifestações artísticas que envolvem um grupo de artistas e técnicos, que desempenham papéis de uma grande diversidade. Como consequência, mostram uma rede criadora bastante densa. Tudo que está sendo descrito e comentado ganha a complexidade da interação (nunca fácil, de uma maneira geral) entre indivíduos em contínua troca de sensibilidades. (SALLES, 2011, p. 56)

\subsection{Quarto trajeto: apresentação do exercício cênico de composição $O$ Sentido de Sente com o Corpo para o público}

A apresentação de nosso exercício cênico intitulado O Sentido se Sente com o Corpo aconteceu em um das salas do Departamento de Artes Cênicas da Escola de Comunicação e Artes da Universidade de São Paulo. O exercício foi aberto ao público nos dias 28 e 29 de setembro de 2013 e contou com a seguinte equipe:

Criação, pesquisa e execução: Kalisy Cabeda e Sissi Betina Venturin; orientação: Sayonara Pereira; textura sonora: Jorge Peña; iluminação: Di Pannacci. Poemas: Josely Vianna Baptista. Fotografia e Filmagem: Di Pannacci, Rafael Avancini e Carolina Rocha. Arte gráfica: Gabriel Bitar. 
Figura 34 - Cartaz de divulgação do exercício cênico: O Sentido se Sente com o Corpo.

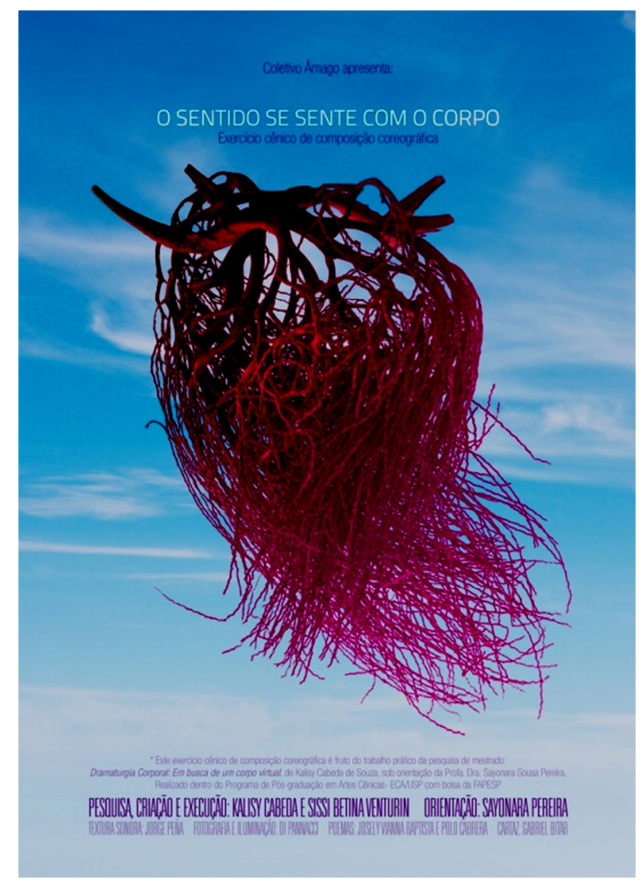

Fonte: Cartaz de divulgação de Gabriel Bitar.

O momento da apresentação foi muito especial, pois se concretizou como final da jornada de experiência e práxis corporal desta pesquisa, sendo muito importante para nós, que tivemos a oportunidade de trocar com outras pessoas o material que vínhamos investigando e onde tínhamos chegado até o momento. Apesar das fragilidades e da ansiedade, conseguimos mostrar para o público o nosso material de forma poética, sensível e sincera. A apresentação do exercício cênico foi registrada através de filmagem e encontra-se na íntegra no DVD em anexo que acompanha esta dissertação de mestrado, ou através do endereço na internet https://vimeo.com/79368998, no qual há um pequeno vídeo editado com trechos da apresentação.

Durante o processo de investigação e criação, nosso objetivo foi elaborar uma linguagem artística fundamentada na fisicalidade poética e singular de cada atriz-bailarina, com a qual foi possível estabelecer uma comunicação através do corpo em um contínuo diálogo cinético/cinestésico. ${ }^{89}$

\footnotetext{
${ }^{89}$ Optamos por utilizar as duas palavras: cinético, no que se refere aos gestos e desenhos corporais e à cinética e dinâmica do movimento da cena, e cinestésico no que se refere às sensações, percepções e camadas de sentidos do corpo, pois, segundo o pesquisador e professor francês Hubert Godard (2002), em seu texto intitulado Gesto e percepção, a experiência visual do espectador provoca no próprio corpo
} 
Até a finalização do exercício, o havíamos apresentado para poucas pessoas (orientadora, músico-sonoplasta, iluminador). Nossa expectativa era grande em saber como outras pessoas receberiam nosso material e também como seria nossa sensação ao apresentar o que vínhamos investigando.

Percebemos que os movimentos corporais adquiriram mais intensidade e potência na presença de espectadores, pois nosso estado físico e emocional se alterou como um todo e influenciou na execução do exercício cênico. Além dessa percepção, foi fundamental para nosso processo escutar alguns comentários do público e suas impressões ao final da apresentação. Assim, constatamos que algumas imagens poéticas e sensações propostas no exercício foram percebidas por eles e outras foram criadas e sentidas a partir de sua própria experiência ao assistir o trabalho:

Acredito que o significado do exercício é justamente a ligação com o intuitivo, com nossa percepção não racional. Lembro-me das pessoas ao final da apresentação dizer que sentiam algo que não era possível explicar. Acho que é mais ou menos isso. (PANNACCl, em entrevista sobre o processo de criação em fevereiro de 2014).

O processo criativo se mostrou como uma seleção e recorte do material utilizado (o corpo cênico de cada atriz-bailarina), que foi lapidado por meio de nossas práxis, percepções e intuições durante a elaboração do trabalho até adquirir uma forma organizada (o exercício cênico). Esta forma organizada desencadeou novas relações e impressões a partir da percepção do espectador sobre o material cênico criado. Nessa direção, acreditamos que o exercício alcançou o resultado almejado, na medida em que foi elaborado através de construções corporais baseadas nas sensações e percepções de cada intérprete e que nossa experiência cinética/cinestésica encontrou reverberação no corpo e na percepção do espectador. Segundo o pesquisador e professor francês Hubert Godard (2002), em seu texto intitulado Gesto e percepção, a experiência visual do espectador é também uma experiência cinestésica que age de forma imediata sobre o corpo e a percepção do observador:

O movimento do outro coloca em jogo a experiência de movimento própria ao observador: a informação visual provoca no espectador uma experiência cinestésica (sensações internas dos movimentos de 
seu próprio corpo) imediata. As modificações e as intensidades do espaço corporal do dançarino vão encontrar ressonância no corpo do espectador. O visível e o cinestésico, absolutamente indissociáveis, farão com que a produção de sentido no momento de um acontecimento visual não deixe intacto o estado do corpo do observador (...). É, então, impossível falar da dança ou do movimento do outro sem lembrar que falamos de uma percepção particular, e que a significação do movimento ocorre tanto no corpo do dançarino, como no corpo do espectador. (GODARD, 2002, p. 24-25)

Assim, Godard (2002) nos traz uma reflexão relevante da percepção do espectador sobre a obra cênica, porém nossos estudos não abarcaram esse tema e nem poderíamos nos debruçar sobre esse tópico no final de nossa jornada de pesquisa, tanto pelo tempo quanto pela complexidade que essa questão envolve. Porém, a noção de percepção particular de Godard (2002) pode sim se relacionar com a nossa experiência investigativa/criativa, pois fundamentamos nossa práxis na percepção particular de cada intérprete sobre sua própria experiência cinética/cinestésica corporal e, por consequência, na fisicalidade singular presente nos gestos e movimentos de cada atriz-bailarina.

Desse modo, em nosso trajeto até a configuração do exercício cênico $O$ Sentido se Sente com o Corpo, percebemos que nosso corpo já possuía em si o potencial poético para ser um ressonador de imagens e metáforas, que nasceram de nossa sensação interna (de nossa atitude interior, segundo Laban) e adquiriram forma e visualidade através de nossa movimentação corporal, de nossos gestos e ações, que já carregavam em si as nossas memórias inscritas no corpo (PEREIRA, 2011). Essas memórias podem ser revisitadas e atualizadas pelos gestos que brotam de nossa percepção particular e se amplificam na percepção e no corpo do espectador que observa visualmente a cena.

Assim, podemos estabelecer uma relação direta com o que nos fala Langer (1980) no primeiro capítulo desta dissertação sobre as forças virtuais, ${ }^{90}$ forças que se atualizam por meio dos gestos dançados e sobre o olhar do espectador, pois ambos (ator-bailarino e espectador) criam um campo de sentido através de seus corpos e de suas percepções. Como nosso próprio título propõe, O Sentido se Sente com o Corpo.

\footnotetext{
${ }^{90}$ As noções sobre forças virtuais encontram-se no primeiro capítulo desta dissertação.
} 
Acredito que o corpo cria sentido através dele mesmo. Este exercício provou que o corpo tem memória e uma linguagem própria, muitas vezes desvinculada de uma consciência mental direta. O trabalho de desenvolvimento das composições de movimento nos trazia imagens e dramaturgias por si só, que com o tempo podiam ser lidas e compreendidas por nós. Era como se o corpo fosse um indivíduo com um histórico particular que se apresentava através do movimento e da relação aos estímulos, falando ao seu interlocutor - ele mesmo e nós, que podíamos nos escutar e reconhecer. (VENTURIN em entrevista sobre o processo de criação em fevereiro de 2014)

E como podemos estabelecer esse sentido que nasce do movimento? Acreditamos que é através da percepção sobre nosso próprio corpo, nossas sensações e nosso movimento interior, ou, como nos propõe Laban (1975), nosso esforço, nossa atitude interior que ganha forma através de nosso corpo e nossos gestos na elaboração de nossa própria assinatura corporal. Esta assinatura que surge de nossa atitude interior e gera as ações e os gestos no espaço/tempo da cena se constitui como nossa fisicalidade singular, nosso texto corpóreo que está fundamentado na caligrafia pessoal e nos permite a elaboração de nossas poesias cênicas.

(...) o intérprete tem capacidade de fazer reviver no seu corpo movimentações, e signos, provenientes das historias que já foram vividas por ele, por seus ancestrais e que de alguma maneira ficaram gravadas no corpo. É possível que ocorra uma espécie de depoimento corpóreo-pessoal onde um transito criativo, intenso e, por vezes até veloz, entre os conhecimentos apreendidos, e em apreensão, combinar-se-ão de tal forma um ao outro que teremos dificuldades de ordenar as experiências armazenadas separadamente. Mesmo assim acreditamos que o intérprete, após alcançar o objetivo, ou seja, o aprendizado do movimento, da ação, ele sonha ainda com a transcendência. (PEREIRA, 2011, p. 10)

Nessa direção, é interessante observar o caminho que realizamos até chegarmos à concretização do exercício cênico. Primeiramente, despertamos o corpo para nossa percepção sutil através de uma consciência corporal desenvolvida dentro da práxis sobre o Sistema Laban e a pedagogia Lecoq nos Laboratórios de Criação. Ao finalizar esse primeiro percurso, podemos fazer uma analogia como se tivéssemos construído um mapa interno de nossos próprios corpos, o que foi possível por meio da conscientização sobre os fatores de movimento (espaço, tempo, peso e fluência em Laban) e dos aspectos sensoriais e imaginários (elementos da natureza em Lecoq). Após realizarmos essa viagem pessoal sobre nossas experiências cinéticas/cinestésicas dentro de cada metodologia estudada, visualizamos esse 
mapa corporal e traçamos os trajetos que nos levaram às escolhas poéticas na elaboração do exercício cênico de composição.

Neste sentido, ao despertar nossa percepção, acessamos nosso mapa corporal, no qual traçamos nossos percursos tendo como guia nossas sequências de movimento (elaboradas nos Laboratórios de Criação), nossas imagens poéticas, nossa sensibilidade e intuição, que, como bússolas, nos orientaram em nossas direções estéticas até a criação do Sentido se Sente com o Corpo. Ao estabelecer esse mapa, conscientizamos nossos movimentos internos (esforço), que adquiriram forma no espaço/tempo da cena através de nossos corpos e gestos visíveis, gestos que concretizaram em coreografia nossas sensações e imagens poéticas.

As imagens poéticas, que se tornaram nossas imagens referenciais, existem em nosso interior como potência, são imagens virtuais que se atualizaram segundo nossos percursos físicos cinéticos/cinestésicos presentes em cada célula coreográfica. Essa atualização se torna possível quando nossa percepção sobre o corpo ou nossa consciência do corpo se torna corpo de consciência, como nos diz Gil, quando o pensamento e sensação (movimento interior) se tornam corpo de pensamento (gestos cênicos), assim o próprio movimento dá sentido ao movimento:

\footnotetext{
O pensamento já não se descreve como pensamento do corpo, mas como corpo de pensamento, quer dizer, tendo a mesma plasticidade, fluência e consistência que os movimentos corporais. Assim, doravante, é o movimento que desencadeia o movimento; é o movimento que orienta o movimento; é o movimento que dá sentido ao movimento. (GIL, 2004, p. 44)
}

Sabemos que essa é uma operação um tanto complexa e que exige um tempo e uma dedicação de trabalho que vão muito além de uma pesquisa de mestrado, mas na qual acreditamos ter avançado um pouco através da elaboração desse exercício cênico de composição e à qual pretendemos dar continuidade enquanto artistas do corpo cênico.

Seguem algumas fotografias da apresentação do exercício cênico $O$ Sentido se Sente com o Corpo. 
Figura 35 - Atrizes-bailarinas: Kalisy Cabeda e Sissi Betina Venturin.



Foto: Rafael Avancini.

Figura 36 - Atrizes-bailarinas: Kalisy Cabeda e Sissi Betina Venturin.

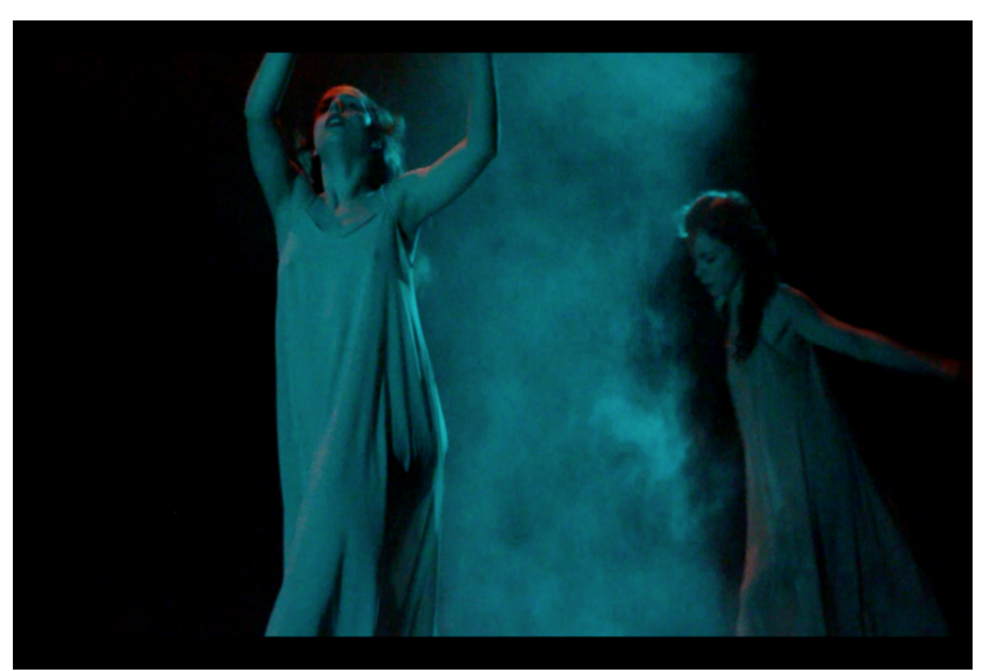

Foto: Rafael Avancini. 
Figura 37 - Atriz-bailarina: Sissi Betina Venturin e o Músico e sonoplasta: Jorge Peña.

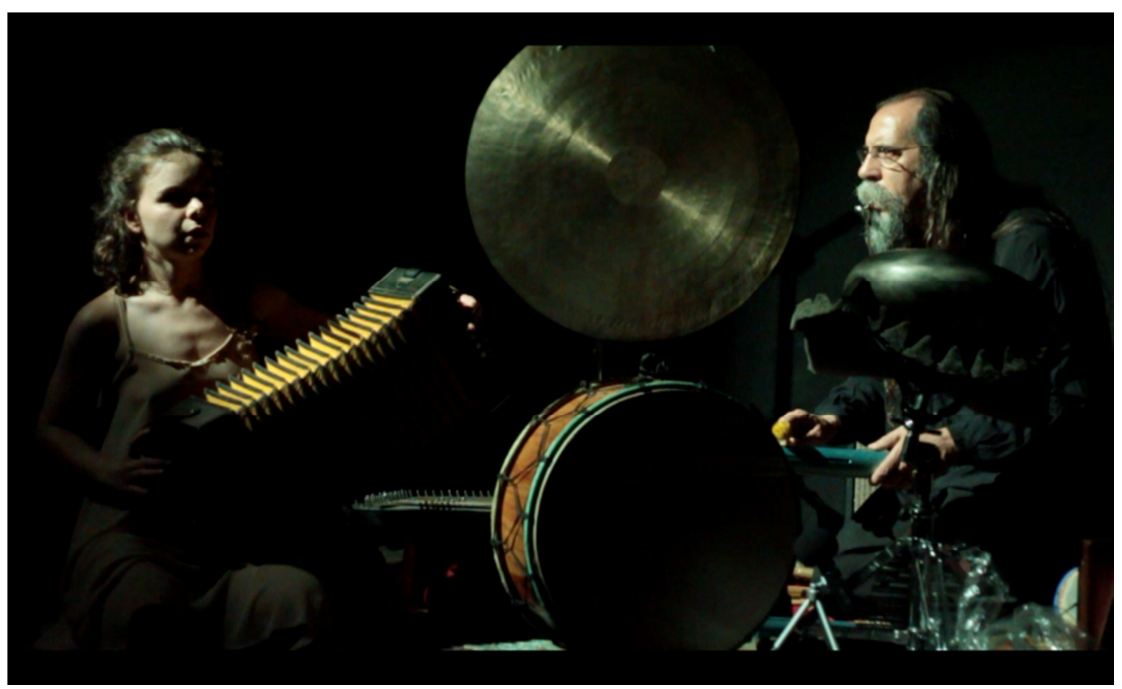

Foto: Rafael Avancini.

Figura 38 - Atrizes-bailarinas: Kalisy Cabeda e Sissi Betina Venturin.

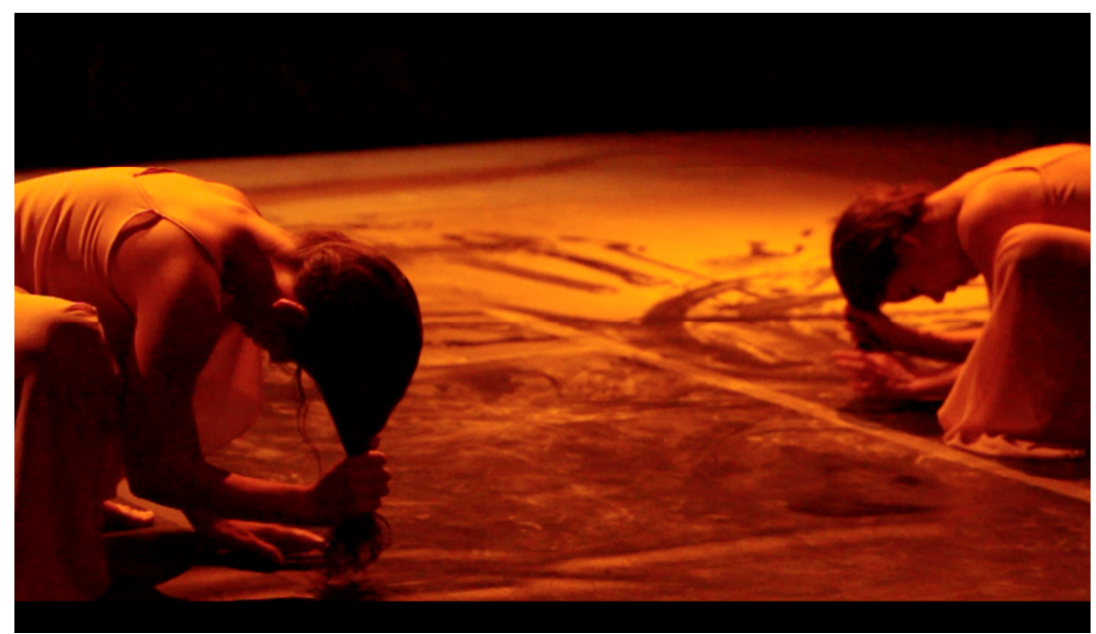

Foto: Rafael Avancini. 


\section{CONSIDERAÇÕES FINAIS}

Nesse extenso percurso descrito ao longo dessa dissertação, muitos aspectos foram contemplados em nossa reflexão e muitos outros não puderam entrar aqui como texto ou em palavra, mas ficaram marcados na experiência de nosso percurso investigativo/criativo/sensorial. Esta experiência foi guiada pela nossa prática de criação, na qual nossa sensibilidade foi transformada ao longo do trajeto feito até aqui. Assim, percebemos que nessa experiência sobre o corpo cênico como operador de linguagem poética, adentramos em uma investigação sobre nossos próprios corpos, nossas próprias percepções, nossas próprias intuições. Dessa forma, esta pesquisa nos possibilitou ampliar o conhecimento sobre nós mesmos e sobre o mundo que conhecemos, pois o que é o nosso corpo se não a ou uma chave para conhecer a nós mesmos e aos outros? Ao conhecermos um pouco mais sobre nós, foi possível elaborarmos certo conhecimento que se concretizou através da práxis, de nosso fazer criativo, um pensamento e reflexão elaborados a partir da experiência do/no corpo (COSTAS, 2010, p. 35), ou, como nos diz Salles (2011), "o conhecimento foi obtido por meio da ação".

\footnotetext{
O percurso criativo pode ser observado sob a perspectiva da construção de conhecimento. A ação do artista leva à aquisição de uma grande diversidade de informações e à organização desses dados apreendidos. Está sendo, assim, estabelecido o elo entre pensamento e fazer: a reflexão está contida na práxis artística (Evandro Carlos Jardim, 1993). O percurso criador deixa transparecer o conhecimento guiando o fazer, ações impregnadas de reflexões e de intenções de significado. A construção de significado envolve referência a uma tendência. A criação é, sob esse ponto de vista, conhecimento obtido pela ação. (SALLES, 2011, p. 127)
}

Desse modo, nosso conhecimento foi produzido a partir de nossa práxis, que teve como objetivo experienciar alguns mecanismos na elaboração de uma linguagem artística fundamentada no corpo cênico e na sua fisicalidade poética. Dentro desse grande objetivo, acreditamos que, chegando ao final, mesmo que provisório, de nossas reflexões, restringimos nossas percepções finais acerca de um aspecto que permeia todo o nosso percurso até aqui: o despertar sobre a consciência do corpo cênico do ator-bailarino através da sua percepção e 
sensação corporal, o que lhe permite acessar inúmeras relações intuitivas e subjetivas que poderão guiá-lo em torno de sua própria expressão e criatividade.

Nessa direção, percebemos que através do desenvolvimento de uma prática de trabalho aprofundada e especializada, como fizemos nesses dois anos de pesquisa, é possível despertar nossa consciência sobre o corpo e acessar nossa percepção sutil na realização de escolhas estéticas. No caso de nossa investigação, foi fundamental empregar uma metodologia que desenvolvesse aspectos técnico-artísticos relativos ao corpo cênico (espaço, peso, tempo e fluência, exercitados no Laboratório de Criação sobre o Sistema Laban), bem como sobre aspectos sensoriais e imaginários (elementos da natureza, exercitados no Laboratório de Criação sobre a pedagogia de Lecoq). Sendo assim, através do desenvolvimento de nossa práxis de pesquisa, aprimoramos a consciência sobre nosso próprio corpo, ampliamos a nossa sensibilidade e acessamos algumas percepções e sensações sutis que são fruto de nossos movimentos internos, de nossa atitude interior.

Assim, através da experiência cinética/cinestésica, adentramos em nossas percepções sutis e abrimos espaço para escutar os movimentos e sensações que pulsam dentro de nós. É como se nosso corpo adquirisse espaços porosos entre o seu interior e o seu exterior, como se nosso corpo fosse tomado pela consciência e percepção e se tornasse um "corpo poroso", abrindo espaço para o diálogo entre seus movimentos internos e seus movimentos externos.

A partir dessa porosidade, abrimos nosso corpo cênico para um sentir cinético/cinestésico, no qual nossa atitude interior (esforço) pode ser traduzida através de nossa corporeidade particular e nossos gestos. Em nosso caso, estamos nos referindo a gestos cênicos que brotam como potência em nosso interior e adquirem forma através de uma fisicalidade poética. Podemos, assim, nos referir a estes como gestos virtuais, que, segundo Langer (1980), se atualizam por meio da gestualidade física singular presente no corpo cênico de cada ator-bailarino. Esse processo de atualização acontece no corpo pelo intermédio de forças físicas, mas também subjetivas, já que a ação e o gesto nascem da vontade interior do intérprete. 
Dessa forma, com base na apropriação da consciência sobre o corpo, o ator-bailarino aprimora sua percepção cinética/cinestésica, acessando sua vontade, sua atitude interior (esforço), que adquire forma na ordenação espacial/temporal de seus gestos cênicos e de sua fisicalidade particular. É através desses gestos singulares que ele vai desenvolver uma narrativa cênica fundamenta em seu próprio discurso corporal.

Ao elaborar uma narrativa cênica baseada em seu próprio texto corpóreo-autoral, o ator-bailarino desenvolve a percepção particular sobre sua vontade e seus impulsos internos (esforço), que brotam em forma de sensações físicas no corpo e geram gestos, ações e composições coreográficas. Nesse sentido, o intérprete vai elaborando sua caligrafia pessoal, que o permitirá escrever com e no seu próprio corpo diferentes poesias cênicas que o levarão ao encontro, como nos diz Laban (1975), de sua assinatura corporal.

$\mathrm{Na}$ experiência de nosso percurso criativo/investigativo, efetuamos um passo adiante na busca por nossa própria assinatura corporal através da elaboração do exercício cênico O Sentido se Sente com o Corpo. Porém, sabemos que ainda há muitos caminhos a percorrer nessa busca e muitos trajetos a serem trilhados enquanto artistas que têm no corpo cênico seu material de criação.

Para finalizar, acreditamos que através de uma apropriação sobre a percepção particular corporal podemos aprimorar a consciência sobre nosso corpo e acessar nossas sensações e movimentos internos, que adquirem forma por meio de nossos gestos cênicos, gestos com qualidades poéticas singulares que são escritos a partir de nossa caligrafia pessoal, caligrafia esta que é elaborada/desenhada a partir de um corpo cênico que apreende diferentes linguagens artísticas e que também é marcado por uma biografia particular permeada de memórias inscritas no corpo, memórias que contêm diferentes experiências, linguagens estéticas, histórias, marcas sociais e culturais que acompanham os gestos e a fisicalidade singular de cada intérprete, que através de suas composições corporais permitem inscrever e reinscrever inúmeros poemas cênicos. 
Deste modo estamos interessados em dialogar com o corpo do intérprete, que é igualmente um corpo poético e social, que suporta signos, os quais trazem marcas das sociedades, e das culturas das quais estes signos se originam; intui gestos, expressões, linguagens corporais, e traduz diferentes visões do mundo. É ainda este mesmo corpo que se deixará inscrever, e se reinscrever inúmeras vezes ao longo de sua história individual se enriquecendo através de diferentes registros e códigos corpóreos. (PEREIRA, 2011, p. 3)

Ao permitir se inscrever e reinscrever em cena inúmeras vezes, o atorbailarino desenvolve e aprimora a escrita de sua própria caligrafia pessoal e, por meio desta, pode elaborar sua assinatura corporal, que lhe permitirá escrever e reescrever o que Laban (1975) denomina como poema do esforço, e Lecoq (1997) como poema em movimento. Assim, criando seus próprios poemas cênicos, o ator-bailarino vai escrevendo e tecendo com o seu corpo um palimpsesto ${ }^{91}$ de poesias.

Que pulse, repulse sóis, tufos, violetas sob um céu pedrento de chuva ou de vento e traduza os fólios da imagem da pele em nuvem lazúli, bulbo de veludo e pulse, repulse sóis, tufos, lilases ao ler os infólios da imagem da pele em palimpsesto: um abrir-se à brasa quando a alma nua se veste de ares e o sol calcina em salamandras rubras a gala sem flor de uma orquídea rara". (BAPTISTA, 1992, p. 23)

\footnotetext{
${ }^{91}$ Palimpsesto era um manuscrito em pergaminho muito utilizado na Idade Média e que após ser raspado e polido, era novamente aproveitado para a escrita de outros textos. Segundo Suquet $(2008$, p. 525) "Laban aborda a corporeidade do homem moderno como um palimpsesto".
} 


\section{BIBLIOGRAFIA}

ANDERSON, Jack. Dança. Lisboa: Editorial Verbo: 1978.

ARTAUD, Antonin. O teatro e seu duplo. 2. ed. São Paulo: Martins Fontes, 1999.

ASLAN, Odette. Le masque: du Rite au Théâtre, études de Odete Aslan, Denis Babet, et all. Paris: Ed. CNRS, 1985. Tradução para fins didáticos de Sofia Salvatori.

. O ator no século XX. São Paulo: Perspectiva, 2003.

BALAKIAN, Anna. Simbolismo. São Paulo: Perspectiva 1985.

BAPTISTA Josely Vianna. Ar. São Paulo: lluminuras, Fundação Cultural/Curitiba (PR), 1991.

Roça Barroca. Tradução (guarani-português) do mito cosmogônico da tribo indígena Mbyá-Guarani. Cosac Naify. São Paulo: SP, 2011.

Corpografia: autópsia poética das passagens. Josely Vianna Baptista, Francisco Faria. São Paulo: Iluminuras, 1992.

BERTHOLD, Margot. História mundial do teatro. 4. ed. São Paulo: Perspectiva, 2008.

BOGÊA, Inês. 0 Mundo em Movimento. Disponível em: http://www.inesbogea.com.br/biografia MariaDuschenes.pdf Acesso em 25 de maio de 2014.

BONDÍA, Jorge Larrosa. Notas sobre a experiência e o saber de Experiência. Universidade de Barcelona, Espanha. 2002

BONFITTO, Matteo. A cinética do Invisível. In: Revista Sala Preta. ECA-USP, 2002.

O ator-compositor. São Paulo: Perspectiva, 2002.

BOURCIER, Paul. História da Dança no Ocidente. São Paulo: Martins Fontes, 2001.

BURNIER, Luís Otávio. A arte de ator: da técnica à representação. Campinas. SP: Ed. Unicamp, 2001.

CARLSON, Marvin. Teorias do teatro. Estudo histórico-crítico dos gregos à atualidade. Tradução de Gilson César Cardoso de Souza. São Paulo: Unesp, 1997. 
COHEN, Renato. Work in Progress na Cena Contemporânea - Criação, Encenação e Recepção. Coleção Estudos. São Paulo: Perspectiva, 1998.

COPEAU, Jacques. <Hay que rehacerlo todo> Escritos sobre el teatro. España: Publicaciones de la Asociación de Directores de Escena de España, 2002.

COSTAS, Ana Maria Rodriguez. As contribuições das abordagens somáticas na construção de saberes sensíveis da dança: um estudo do projeto "Por que Lygia Clark?". 2010. 248 p. Tese (Doutorado em Educação) - Faculdade de Educação da Universidade Estadual de Campinas, Campinas, 2010.

. Corpo veste cor: um processo de criação coreográfica. Dissertação (Mestrado). Universidade Estadual de Campinas, Instituto de Artes. 1997.

CRAIG, Edward Gordon. Da arte do teatro. Lisboa: Arcádia, 1963.

DELEUZE, Gilles; PARNET, Claire. Dialogues. Paris: Flammarion 1996.

DELEUZE, Gilles. Diferença e repetição. 2.ed. rev. atual. Rio de Janeiro: Graal, 2006.

DESLAURIERS, Jean-Pierre. Recherche qualitative. Guide pratique. Montreal: McGraw-Hill, 1991, 142 p.

DUBRAY. Dossiê: Dança e Dramaturgia. Bruxelles: Contredanse, 1997.

FERNANDES, Ciane. O corpo em movimento: o sistema Laban/Bartenieff na formação e pesquisa em artes cênicas. 2. ed. São Paulo: Annablume, 2002.

FLICK, Uwe. (Org.). Qualidade na pesquisa qualitativa. Artmed Editora S.A. (Tradução); Porto Alegre: Artmed Editora S.A. 2009.

FORTIN, Sylvie. Arte e ciência: abismo de rosas: o processo formativo como construção de novos procedimentos criativos. In $6^{\circ}$ Congresso ABRACE. 2010.

FRAGA, Eudinyr. O simbolismo no teatro brasileiro. São Paulo: SP Art \& Tec Editora, 1992.

GERHARDT E. Tatiana; SILVEIRA T. Denise. (Orgs.). Métodos de pesquisa. Coordenado pela Universidade Aberta do Brasil - UAB/UFRGS e pelo Curso de Graduação Tecnológica - Planejamento e Gestão para o Desenvolvimento Rural da SEAD/UFRGS. - Porto Alegre: Editora da UFRGS, 2009.

GIL, José. Metamorfoses do corpo. 2.ed. Lisboa : Relógio D'Água, 1997. 
Movimento total: o corpo e a dança. São Paulo: Iluminuras, 2004.

. O Corpo do Bailarino. Conferência apresentada na Universidade de Columbia, Nova Iorque, em seminário sobre Gilles Deleuze e Felix Guattari, em abril de 1999.

GODARD, Hubert. Gesto e percepção. Tradução de Silvia Soter. In: PEREIRA, Roberto; SOTER, Silvia. (Org.). Lições de Dança 3. Rio de Janeiro: UniverCidade Editora, 2002. p.11-35.

. La dance au XXème siècle. / Marcelle Michel e Isabelle Ginot. Paris: Bordas, 1995.

GREINER, Christiene. O corpo: Pistas para estudos indisciplinares. São Paulo: Annablume, 2005.

GROTOWSKI, Jerzy. Em busca de um teatro pobre. 3.ed. Rio de Janeiro : Civilização Brasileira, 1987.

Tu Eres Hijo de Alguien. Revista Máscara-Escenologia, n 11-12. Ciudad del México: jan.1993.

HOLANDA, Aurélio Buarque. Mini Dicionário Aurélio da Língua Portuguesa. Curitiba: Editora Positivo, 2011.

JOUSSE, Marcel. A Antropologia do Gesto. Paris: Resna, 1969.

KANTOR, Tadeuz. O Teatro da Morte. São Paulo: Editora Perspectiva, 2011. 1988. Scuola Elementare Del Teatro - Lezioni Milanesi. Milano: Ubulibre,

KERKHOVE, Marianne Van. Dossiê Dança e Dramaturgia. Tradução de Cássia Navas. Bruxelas: Contredanse, 1997.

LABAN, Rudolf von. Choreotics. London: MacDonald/Evans, 1976.

. Dança Educativa Moderna. São Paulo: Ícone, 1990.

. Domínio do movimento. 3. ed. São Paulo: Summus, 1978.

LANGER, Susanne Katherina Knauth. Sentimento e forma: uma teoria da arte desenvolvida a partir da Filosofia em nova chave. São Paulo: Editora Perspectiva, 1980.

LAUNAY, Isabelle. Laban ou a experiência da dança. In: PEREIRA, Roberto; SOTER, Silvia. (Org.). Lições de dança 1. Rio de Janeiro: UniverCidade Editora, 1999. p. 73-90. 
LECOQ, Jacques. Del mimetismo a la imitación. Máscara, ano 3, n. 13-14, México, 1993.

. Le corps poétique. Un enseigment de la créacion théâtrale. Paris: Actes Sud-Papiers/ANRT, 1997.

. Le théatre du geste. Paris: Bordas, 1987.

O Corpo poético: uma pedagogia da criação teatral. Com a colaboração de Jean-Gabriel Carasso e de Jean Calude Lallias; tradução de Marcelo Gomes. São Paulo: Editora Senac. Edições SESC SP, 2010.

Rôle du masque dans la formation de l'acteur.In: Le masque du rite au théâtre. Paris: CNRS, 1985, p. 265-268.

LEHMANN, Hans-Thies. Teatro pós-dramático. São Paulo: Cosac Naify, 2007.

LOPES, E. P. A máscara e a formação do ator. Tese (Doutorado em Artes). Universidade Estadual de Campinas, Instituto de Artes, 1991.

LOUPPE, Laurence. Lygia Clark não pára de atravessar nossos corpos. In: ROLNIK, S. (Org.). Lygia Clark, da obra ao acontecimento. Somos o molde. A você cabe o sopro. São Paulo: Pinacoteca do Estado, 2006. p. 33-39.

MEIRHOLD, V. O Teatro de Feira, in Na cena do Dr. Dapertutto: poética e pedagogia em V.E.Meierhold: 1911 a 1916. São Paulo: Perspectiva: FAPESP, 2009.

MURRAY Simon. Jacques Lecoq. London: Routledge, 2003.

NAVAS, Cássia e LOBO, Lenora. Teatro do movimento, um método para o intérprete - criador. Brasília: LGE, 2003

NAVAS, Cássia. Dança: Escritura, Análise e Dramaturgia. São Paulo: ECAUSP/2001- Memória.

OIDA, Yoshi. O Ator Invisível. São Paulo: Beca, 2001.

OSTROWER, Fayga. Criatividade e Processos de Criação. 29.ed. Petrópolis: Vozes, 2013.

PAVIS, Patrice. Dicionário de teatro. São Paulo: Perspectiva, 1999.

PEREIRA, Sayonara. Corpos que esboçam memórias. ANDA - anais do $2^{\circ}$ Encontro Nacional de pesquisadores em dança. Dança: contrações epistêmicas- Porto Alegre- 2011. 
2010)

2006

Memória e Identidade. Encontro Arte Educacão -Montenegro-RS -

Pulsações e Ações da Memória Materializados em Cena. 2012.

Disponível em: http://lapettcia.files.wordpress.com/2013/02/sayonara-pereirapulsac3a7c3b5es-e-ac3a7c3b5es-da-memc3b3ria-materializados-em-cena2012.pdf Acesso em 23 de maio de 2014.

Rastros do Tanztheater no processo criativo de ES-BOÇO: espetáculo cênico com os alunos do Instituto de Artes da UNICAMP, São Paulo. Ed. Annablume . 2010.

Rastros do Tanztheater no processo criativo de ES-BOÇO: espetáculo cênico com os alunos do Instituto de Artes da UNICAMP. Tese (Doutorado). Universidade Estadual de Campinas, 2007.

Tanztheatralidade: história-características ferramentas empregadas. Cadernos de Pós-Graduação da UNICAMP, v. 8, p. 75-80, 2006.

PICON-VALLIN. B. A arte do Teatro: entre a tradição e vanguarda. Rio de Janeiro: Folhetim, 2006.

PORTINARI, Maribel. História da dança. Rio de Janeiro: Nova Fronteira, 1989.

PRONSATO, Laura. Composição Coreográfica: uma intersecção dos estudos de Rudolf Laban e da improvisação. Dissertação (Mestrado). Universidade Estadual de Campinas, Instituto de Artes. 2003.

RENGEL, Lenira. Dicionário Laban. São Paulo: Ed. Annablume, 2003.

RIBEIRO, Antônio Pinto. Dança temporariamente contemporânea. Lisboa: Passagens, 1994.

ROUBINE, Jean-Jacques. A arte do ator. Rio de Janeiro: Ed. Jorge Zahar, 1995.

SACHS, Cláudia Muller. A imaginação é um músculo: a contribuição de Lecoq para o trabalho do ator. Tese (Doutorado). Universidade do Estado de Santa Catarina, Programa de Pós-Graduação em Teatro, Florianópolis, 2013.

Metodologia de Jacques Lecoq: estudo conceitual. Dissertação (Mestrado). Universidade do Estado de Santa Catariana, Mestrado em Teatro 2004.

SALLES, Cecília Alemida. Gesto Inacabado processo de criação de criação artística. $5^{\circ}$ edição. São Paulo: Intermeios, 2011. 
SARRAZAC, Jean-Pierre (org). Léxico do drama moderno e contemporâneo. São Paulo: Cosac \& Naify 2012.

STANISLAVSKI, Constantin. El trabajo del actor sobre si mismo en el proceso creador de la encarnación. Buenos Aires: Editorial Quetzal, 1997.

SUQUET, Annie. Cenas. O corpo dançante: um laboratório da percepção. In: COURTINE, Jean-Jacques (Dir.). História do Corpo vol. 3: As mutações do olhar. O século XX. Petrópolis: Vozes, 2008. p. 509-539.

SZONDI, Peter. Teoria do drama moderno 1880-1950. São Paulo Cosac \& Naify, 2001.

TARTUCE, T. J. A. Métodos de pesquisa. Fortaleza: UNICE - Ensino Superior, 2006. Apostila.

THAIS, Maria. Na cena do Dr. Dapertutto: poética e pedagogia em V.E. Meierhold: 1911 a 1916. São Paulo: Perspectiva: FAPESP, 2009.

WEISZFLOG, Walter (Editor). Michaelis: moderno dicionário da língua portuguesa. São Paulo: Melhoramentos, 1998.

ZAMBONI, Sílvio. A pesquisa em Arte. Campinas: Autores Associados, 1998. 


\section{ANEXO - ENTREVISTAS}

Entrevistas realizadas com a atriz-bailarina Sissi Betina Venturin ${ }^{92}$, com o músico e sonoplasta Jorge Penã ${ }^{93}$ e com o iluminador Di Pannacci ${ }^{94}$.

Questionário sobre o Laboratório de Criação - segundo semestre de 2012, Respondido por Sissi Betina Venturin em dezembro de 2012.

\section{Quais são as mudanças técnicas que observou no seu corpo a partir do trabalho prático sobre os exercícios de Laban?}

O trabalho com os exercícios de Laban foram muito importantes para o aprimoramento e expansão do meu repertório corporal e qualidade de movimento. Com este estudo prático percebi que conheci novos pontos de impulso no corpo, como vetores, para a dança. A cada ensaio sentia que a variedade de movimento e a fluidez de composições improvisadas melhoravam devido às novas compreensões praticadas. Meu corpo está se tornando mais presente e criativo, a dinâmica de Laban experimentada liberta a criatividade da dança através das ferramentas sensíveis que desenvolve no bailarino.

\section{A noção de corpo, espaço e tempo modificou alguma coisa para a sua percepção corporal? Aponte algum exemplo.}

Sim, sinto que ainda estão reverberando estas novas compreensões. A noção de corpo se ampliou muito, todo o trabalho que é feito com o corpo físico

\footnotetext{
92 Sissi Betina Venturin é atriz formada em Licenciatura em Teatro pela Universidade Estadual do Rio Grande do Sul (UERGS). Atualmente vive em São Paulo e é integrante do Coletivo Âmago, que pesquisa a dança, o teatro e o cinema em relação com espaços públicos. Participou da criação do exercício cênico de composição O Sentido se Sente com o Corpo, que fez parte do processo prático dessa pesquisa de mestrado.

93 Jorge Peña nasceu no Uruguai, é fotógrafo, músico, percussionista e sonoplasta. Iniciou sua carreira em 1977 em Montevideo, quando apresentou "Entre Pitos y Flautas", de Ricardo Fontana, e coreografias de Adriana Lagomarsino. Participou de uma turnê com Mercedes Sosa pelo Brasil em 1987. No teatro, integrou o Grupo Ornitorrinco e, até hoje, faz parte da Companhia de Teatro Pessoal do Faroeste, do diretor Paulo Faria. Participou da criação do exercício cênico de composição O Sentido se Sente com o Corpo, que fez parte do processo prático dessa pesquisa de mestrado.

94 Diretor de Fotografia pós-graduado na Escuela de Cine y Televisión de Madrid. Fotografou diversos curtametragens, entre eles, "En Mi Burbuja", filmado em $16 \mathrm{~mm}$, ganhador do prêmio de melhor fotografia no concurso "Kodak Film School Competition" na Espanha no ano de 2011. Também fotografou o longametragem "Paisagens do conhecimento", exibido no Canal Brasil. Trabalhou como iluminador com o grupo de teatro andaime em Piracicaba. Realiza trabalhos audiovisuais com o "Coletivo Âmago". Participou da criação do exercício cênico de composição O Sentido se Sente com o Corpo, que fez parte do processo prático dessa pesquisa de mestrado.
} 
expande-se para um entendimento do corpo coletivo, social, astral também. Composto de matéria e sensação, informações e atitude, o corpo tem muitas formas, são múltiplos corpos em comunicação em todo o espaço. Em relação ao meu corpo humano individual, percebo que com este trabalho ele cresceu em energia, que seu movimento atinge ao infinito. Sinto que o espaço é tocado pelo corpo e até movido por ele, o espaço se transforma com o movimento. $O$ tempo em relação a tudo, a cada passo, é agora uma potência variante, como se fosse uma massa moldável, acelerável, pausível. Este estudo engrandece o valor de cada forma que colabora para a dança, que é a vida em sua vitalidade.

3. Realizar as ações de esforço (pontuar, deslizar, chicotear, socar, espanar, torcer, flutuar, pressionar) foi importante para o seu desempenho corporal? Acha que fechar uma sequência para cada ação auxilia na aprendizagem dessas ações?

Acho que são justamente estas variações de possibilidades de movimento, com esta pesquisa prática, que expandem a qualidade da dança e possibilitam, de uma forma bem objetiva, o desenvolvimento da inteligência corporal. O bailarino compreende os diferentes estados corporais e pode transitar entre eles em sua improvisação de movimento. A tarefa de criar uma sequência ao final do ensaio é interessante para o exercício coreográfico, bem como de assimilar as novas informações coletando material para uma composição. Esta prática reforça o que foi aprendido, afirmando o compromisso de observar-se enquanto atuante.

4. Ao trabalhar de forma a unir as duas ou mais ações de esforço, como por exemplo: torcer e chicotear, o que você observou? Acha importante unir as ações, ou acha mais interessante trabalhar elas separadamente ou acha que os dois são importantes?

Acho que os dois são importantes. Este trabalho fala justamente das diferentes formas de movimento e que elas estão participantes em nossa vida, em relação. Compor a dança levando em consideração os diferentes ritmos e suas variantes dá cor e dinâmica ao exercício, estimula a transformação dos estados físicos e o jogo entre eles. 


\section{Como é para você aprender a sequência de ação que o outro criou, acha importante? $\mathrm{O}$ que seu corpo aprende?}

Cada corpo tem sua história, sua personalidade. O movimento que ele cria diz respeito às suas experiências de vida, é um texto que vem desta alma particular falado na sua língua própria. Experimentar a sequência de ação do outro é como estar nele e sentir o que ele quer dizer. Este ato é político, nos coloca em relação mais que de diálogo, de compreensão do ser. Esta experiência liberta e ensina, aprendemos com o outro, sentindo no corpo movimentos que não teríamos criado sozinhos, como se aprendêssemos a ser novo.

\section{Comentário final sobre o semestre de trabalho apontando suas críticas e sugestões para 0 ano que vem. Lembre que é muito importante perceber e indicar as suas percepções corporais sobre o trabalho.}

Ao mesmo tempo que a técnica do trabalho é objetiva e clara, é também poética, de compreensões maiores e metafóricas. Através do corpo nos comunicamos com o mundo e a matéria, seus movimentos imitam as formas exteriores, os ritmos, aprendendo com elas. Laban coloca em ações bem definidas muitas possibilidades de compor e dançar, que são flexíveis para serem desenvolvidas em diferentes estilos de dança, personalidades, temas. Estou muito feliz com este trabalho, espero que no ano que vem ele siga sendo tão rico e sensível. Sinto meu corpo mais livre, mais belo em si, em descobrirse nesta investigação. Percebo que conheço mais possibilidades de movimento e isto enriquece minha maneira de dançar e ser, também de observar a vida e a arte em todo o movimento da natureza. 
Questionário sobre o Laboratório de Criação - primeiro semestre de 2013. Respondido por Sissi Betina Venturin Garcia em maio de 2013.

1. Neste primeiro semestre retomamos 0 trabalho realizado no ano passado, que foram as oito ações básicas de esforço do Laban (socar, pontuar, chicotear, espanar, flutuar, deslizar, torcer, pressionar). Como foi para você retomar essas sequências, o que percebeu em seu corpo? Quais foram as mudanças, diferenças, facilidades e percepções?

Retomar as sequências foi muito importante. Depois do tempo de pausa entre os semestres, rever o trabalho produzido anteriormente foi como um reconhecimento de si na dança, visualizando o percurso evolutivo que estamos caminhando neste processo. Muito interessante foi retomar ambas as sequências de cada ação, as de minha autoria e as da Kalisy, pois assim experimentamos no corpo a escrita coreográfica uma da outra, o que nos ensinou sobre a diferença de nossas dinâmicas, natureza e especificidades de movimento. Retomar a pesquisa a partir desta troca se tornou muito mais rico, pois inevitavelmente nos transformamos enquanto coreógrafas, reconhecendo nossas personalidades em dança. No decorrer dos encontros em abril e maio é evidente a expansão de vocabulário que cada uma de nós está vivendo, a complexidade das novas criações está cada dia mais interessante.

Impactante também foi como nossos corpos estavam desestabilizados logo no inicio dos encontros. Depois da pausa no verão, voltar a dançar retomando as sequências que havíamos criado durante os intensos meses de trabalho no ano anterior nos causava tontura e enjoo, nossos corpos estavam desacostumados, cansavam e se sentiam sobrecarregados. O que nos confirma que a prática continuada dos exercícios fortalece o corpo, tonifica o ser em seu vigor de ação e ritmo. Por termos parado durante as férias, estávamos desacostumadas com tal atividade física, com movimentos que nós mesmas havíamos criado. Com a pratica continuada, nos adaptamos à dinâmica e retomamos o lugar de força e agilidade de antes, agora ainda mais expandido! 
2. Como foi realizar o trabalho das seis ações incompletas e dos três ímpetos de ação do Laban, no quesito corpo? Quais foram as diferenças na hora da criação nestas sequências para as primeiras ações do Laban?

Como coloquei anteriormente, começar o estudos das ações incompletas e ímpetos de ação do Laban se tornou muito mais rico depois de termos retomado as coreografias das oito ações de esforço criadas por nós duas. As ações incompletas, por abordarem apenas dois aspectos das qualidades de movimento, trazem mais variação de dinâmica numa mesma prática, uma liberdade um pouco maior, o que as torna mais fluidas e particularmente interessantes. Um ponto que, em minha opinião, colaborou bastante e delicadamente para nossas novas criações coreográficas, foi termos praticado no pátio da USP, na grama, no sol, com pássaros e flores em relação conosco na paisagem. O espaço expandido e rico da natureza estimulou nosso corpo e sentimento na dança, abrindo nossas ações para o espaço mais amplo e interferências de formas, cores, sons, etc.

Esta riqueza de vocabulário e paisagem, agregada à maleabilidade de atitude estimulada pelo espaço externo do pátio e pelas lacunas presentes na prática das ações incompletas, nos convidou a experimentar nosso ser criativo mais detalhado e cheio de nuances. Da mesma maneira com os ímpetos de ação. As sequências criadas neste novo momento estão mais diversificadas dentro de cada uma, percorrem trajetórias mais dinâmicas e até mais longas. Nossos corpos e mentes estão acostumando a ver-se durante a improvisação e registrar o que lhes interessa para em seguida dedicarem-se a compilar os movimentos mais interessantes. Esta prática continuada nos traz uma visão muito presente sobre nossos corpos dançando, abre o olhar por todas as partes como atentos olhos sensores internos e externos, visualizando os percursos de ação e intenção e marcando sua história desde o rascunho.

A grande diferença entre os dois momentos, na minha opinião, é que nas ações de esforço temos um território delimitado de atividade, com suas três qualidades determinadas que permitem uma imensa possibilidade de ação, mas que se mantém mais fechado por elas. É muito rico, pois há infinitas formas de agir neste contexto, mas é como se a ação fosse sempre assinada pela mesma personalidade. Agora, nas ações incompletas e ímpetos de Laban, há um território elástico com portas e janelas abertas para paisagens que vão se transformando a 
todo momento. Dentro de uma mesma ação, há diferentes seres e estares, personalidades, estilos, unidos por uma fluidez de transformação.

\section{Como foi realizar o trabalho das transferências das matérias do Lecoq? Como foi que o seu corpo respondeu ao estímulo da imaginação e do jogo que está presente no processo de criação do trabalho?}

Lindo este trabalho de Lecoq! A qualidade de movimento que ele gera é diferente do trabalho de Laban. Comentamos em um dos ensaios que estávamos nos movendo como dança Butoh, criando coreografias com princípios de movimento mais internalizados, de imagem, detalhes e dinâmicas mais sutis. A questão da imaginação, bem presente neste trabalho, nos trouxe um entendimento sobre o que é o ser no ambiente e a relação entre eles. Durante o exercício de imaginação, criamos paisagens "ao nosso redor", de olhos fechados. Mas estas paisagens estão na verdade dentro de nós, nós somos elas. Projetamos uma montanha no horizonte, uma fogueira, mas montanhas e fogueira somos nós. O corpo corresponde a este estado de paisagem, a este sentir-se tão imenso e material, também abstrato e substancial na qualidade da atmosfera que estas imagens geram na musculatura e no ser como um todo. Me lembro que depois de um ensaio saímos da sala um instante e senti que a paisagem do pátio também era eu, do mesmo modo como com a imaginação. Através do olhar eu percebia a paisagem e podia senti-la dentro de mim, eu era ela, ela era eu, nos penetrávamos.

4. Quais as diferenças que você percebeu entre o trabalho corporal de Laban e Lecoq, quais foram os pontos em comum e quais foram as diferenças?

O trabalho de Lecoq, assim como das ações de esforço de Laban, cria universos particulares de vivência. Cada ação de esforço, assim como cada elemento da natureza, são temas delimitados e imensos de exploração imagética e sensorial, extremamente específicos em suas qualidades. As coreografias criadas nestes trabalhos são células de ações bem diferentes umas das outras, cada uma pertence a uma força e energia. Esta semelhança é justamente o que as torna tão diferentes. Por serem intensas e profundas em suas especificidades e abordarem temas distintos, as ações de Laban e Lecoq geram materiais coreográficos muito variáveis. Os estímulos de Lecoq, que são 
as formas da natureza, geram vivências coreográficas particulares, pois o entendimento e sentimento de cada manifestação é pessoal e traz à tona no corpo dinâmicas energéticas únicas. Há dentro de cada manifestação da natureza uma imensa gama de possibilidades de formas e também uma fluidez entre tais possibilidades, que tornam sua dança mais parecida à da prática das ações incompletas ou ímpetos de Laban, no sentido de possuírem mais nuances e particularidades emocionais. Ou seja, ambas as práticas tocam questões semelhantes, que é o debruçar-se sobre um lugar único e um estado específico do ser, encontrando toda a ambiguidade e possibilidade de sê-lo.

A pesquisa de Lecoq, por abordar os elementos da natureza em toda sua complexidade e liberdade, gera um estado de dança muito misterioso e delicado, onde trazemos o olhar para pequenas danças, sutis comportamentos e também enormes movimentos, mas que não são coreografados por desenhos do corpo no espaço e sim por energia motivadora. Fica uma sensação de que as coreografias de Lecoq são feitas de paisagem, de cor, textura e memória. Temos a imagem do músculo sendo metal, do corpo sendo água, do ventre sendo fogo, do pescoço crescendo como um galho de árvore, de uma gota formando-se no quadril, da ponta do dedo endurecendo como pedra, ou de um rabisco no espaço de faíscas que não têm forma e sim energia motivadora que vibra um "S" no ar. Ao assistir uma coreografia desta pesquisa, pode-se ver a alma de quem dança em algum lugar tão profundo/distante e tão interno/presente do ser, a sua energia vertendo do corpo em presença dedicando-se a ser o todo e transformar-se em detalhes. Mais do que forma, o corpo dança energia, personalidade. É um trabalho muito lindo e sensível, infinito.

5. Você percebe que em Laban o trabalho parece mais técnico e lógico, enquanto em Lecoq o trabalho parece ser mais imaginativo e intuitivo? Ou para você esta diferença não foi perceptível ou relevante?

Sim, completamente! Como coloquei no parágrafo anterior, o trabalho de Lecoq aborda universos específicos, mas imensamente variantes, considerando as subjetividades de cada pessoa e a força da natureza neste dialogo. É muito libertador e delicado, pois une as forças humanas e dos elementos, agrega o ser inteiro. O trabalho de Laban também se debruça sobre 
universos específicos e gera percepções filosóficas sobre as dinâmicas das relações, mas toca questões mais objetivas e práticas do comportamento.

6. Você se identifica mais com um dos processos, Laban e Lecoq, que o outro? Por quais motivos, pela afinidade, pelo desafio?

Eu estou gostando muito de trabalhar os dois. Acho que eles se somam e ampliam um ao outro. Gosto particularmente de trabalhar as forças da natureza, por isso mesmo foi tão interessante desenvolver parte da pesquisa de Laban na rua, no pátio, por trazer mais qualidade do dialogo do corpo com o espaço e agregar estas inspirações. Acredito que cada passo do trabalho foi mais intenso devido à prática que o antecedeu, ou seja, não teríamos chegado a tal qualidade de movimento na pesquisa de Lecoq se antes não tivéssemos passado pelas ações de Laban.

7. Quais são as percepções que você tem do seu corpo após esse trabalho de instrumentalização do corpo, dentro dos fatores de movimento do Laban e das transferências das matérias do Lecoq? Quais são as mudanças, você acha que esse trabalho influencia em seu corpo em outros lugares e momentos da sua vida para além do local de ensaio?

Sinto que tenho dançado mais a vida. Antes deste trabalho eu tinha a ideia limitante de que para ser bailarino era preciso ter muita técnica e prática em algum estilo. Depois deste trabalho a dança se tornou uma força que, acredito, precisa ser vivida por todos. A dança é uma escrita particular de cada corpo, contém infinitas possibilidades de ser, cheia de sutilezas e magnificência. Ela se tornou, para mim, totalmente mais possível. E com esta ideia, muitas outras decisões se tornam mais possíveis. Acredito que isto se deve a este trabalho ter me aproximado de mim mesma objetiva e subjetivamente, pois ele propõe um reconhecimento do ser em si, em seu corpo e ações, mas também um enorme horizonte de possibilidades e diálogos, uma prática permanente de escuta e transformação.

Tenho me sentido mais sensível para as coreografias do cotidiano, das paisagens, das pessoas, relações. Meu corpo se vê mais integrado aos ambientes e a si mesmo, posso recordar momentos através de meus atos corporais, compreendo minhas intenções e respostas pela forma como meu corpo age nas circunstâncias. Maravilhosa sensação de querer dançar em qualquer lugar, de querer deitar no chão, ter todo o espaço como companheiro e quebrar suas institucionalizações. A dança está muito diversificada, pode ser sutil mínimo 
dialogo entre mãos ou palavras e também saltos pelas avenidas. O corpo está mais atento, cheio de olhos e bocas e ouvidos. Esta liberdade interior de dialogar consigo mesmo e compreender as diferenças gera confiança, pois há entrega e dedicação em dar e receber, de si e do todo.

\section{Comentário final sobre o processo de trabalho apontando suas críticas e sugestões. Lembre que é muito importante perceber e indicar as suas percepções corporais sobre o trabalho.}

Ambos os artistas que estamos pesquisando, Laban e Lecoq, têm pesquisas de uma vida, que não poderão ser abordadas em toda sua complexidade no período que estamos dedicando a elas. Sinto que deveríamos ter mais tempo para experimentar cada uma das ações para realmente compreender com todos os corpos (físico, emocional, psicológico etc.) o que cada uma significa. Esta é uma percepção que não serve só para este caso, mas também para a maior parte das ações e relações da sociedade atual. 0 espaço de dois anos de mestrado se torna, portanto, quase simbólico de um rascunho do que deve ser o início de uma caminhada muito mais profunda em pesquisa. O que nos traz uma sensação reconfortante e inteligente quando percebemos que, assim como cada ação delimitada de Laban e Lecoq abre um universo gigante de especificidades, cada indivíduo em sua pesquisa deve mergulhar fundo para encontrar seu universo particular e imenso de personalidade e arte. Mas estamos vivendo uma geração que tem acesso a tudo e o capitalismo nos coloca num lugar de valorização mais quantitativa que qualitativa, pois os valores materiais se sobressaem.

Este trabalho delicado, portanto, chama atenção para a escuta e o respeito das diferenças e encontra nelas sua força. Através dele compreendo melhor que sou um ser particular e que não posso e não preciso querer ser o outro ou tudo, mas o todo em minha particularidade única refletido. Que quanto mais profundo eu for numa direção, mais caminhos se abrem dentro deste campo. E, então, posso olhar o outro com admiração e reconhecê-lo com respeito, não invadi-lo e querer sê-lo ou delimitá-lo por consumismo e ambição! Mas sim dialogar com ele, desfrutar da sua paisagem onde penetro e que me penetra e já somos juntos, relaxar, confiar e dançar com ele! 
Questões sobre o exercício cênico: O Sentido se Sente com o Corpo

Respondido por Sissi Betina Venturin Garcia em fevereiro de 2014

1. Ao longo do processo de pesquisa corporal, realizamos um processo desde Laban e Lecoq até o exercício cênico $O$ Sentido se Sente com o Corpo. Para você, quais são as diferenças entre executar as sequências de movimento criadas para cada artista estudado e executar o exercício cênico? Como, em seu processo de pesquisa, essas sequências se tornaram parte de uma criação artística? Como isso se deu para você, de que forma isso aconteceu em seu corpo?

O exercício cênico demandou um novo olhar sobre as sequências. $O$ processo de revisitar cada sequência para compor com elas frases maiores e um espetáculo foi muito rico, pois pudemos encontrar diferentes nuances nos movimentos, percebê-los melhor estruturalmente, lidar com as sequências como partes de um quebra-cabeça, que podiam ir e vir em relação umas às outras, gerando diversos "textos". Encontrar as oposições e semelhanças de movimento e atitude das sequências foi muito interessante no processo de relacioná-las para compor o grande movimento ao qual elas pertenceriam. Recapitular a inspiração que gerou a criação das sequências foi importante estudo, que nos mostrou como o corpo pode se imbuir de várias dinâmicas durante os movimentos, oscilando e acrescentando densidades.

2. Quais são as diferenças e semelhanças corporais que você percebe nos aspectos peso, fluxo, tempo e espaço, na criação e execução do exercício cênico em comparação com a criação das sequências individuais?

Durante o exercício cênico fica claro que estes aspectos podem ser transformados. Eles foram o mote de criação para as sequências, mas depois que o desenho do movimento existe ele pode assumir diferentes dinâmicas e inclusive transforma-se com relação aos aspectos tempo, fluxo, espaço etc. $\mathrm{Na}$ nossa criação cênica, buscamos lembrar ao corpo as forças que inspiraram os movimentos, tornando as dinâmicas muito vívidas e aprendendo que elas podem variar muitíssimo em atitude, gerando uma riqueza de detalhes, tanto para quem dança, quanto para quem assiste. 
3. Ao passar pelo processo de pesquisa, você percebeu modificações em seu corpo, tanto em níveis físicos, como expressivos. Como isso aconteceu? Como você percebeu que a pesquisa corporal sobre Laban e Lecoq inspirou essas modificações e transformações?

Completamente transformada a relação física e criativa do corpo, do corpo com meus pensamentos, do corpo com o espaço, com minha intenção, criação, com a presença! Este trabalho sensibilizou o corpo e desenvolveu uma tal inteligência própria que ele descobriu-se. Sinto que eu aprendi mais sobre mim através de meu corpo. Somos um mesmo ser (eu e meu corpo), mas o exercício tornou-o mais liberto, surpreendendo-me inclusive com as respostas geradas. Como se ele - o corpo - fosse independente e inteligente, retribuindo a intenção do exercício e gerando uma interação infinita de evolução.

4. Em sua opinião como o trabalho prático de pesquisa realizado com Laban e Lecoq, colaborou para a criação do exercício cênico? Este processo foi fundamental?

Foi fundamental, com certeza! O trabalho prático com as metodologias de movimento dos dois artistas foi a ferramenta que aprimorou o vocabulário dos corpos e que gerou as células coreográficas primeiras, cujas potências dinâmicas reverberaram em tudo.

5. No trabalho corporal desenvolvido, tanto em Laban quanto em Lecoq, utilizamos imagens internas que nos auxiliaram na criação das sequências de movimento (a cinesfera, o plano da porta e da mesa, a água, o fogo, entre outros). Como você percebe que essas imagens, que vêm de nossa imaginação, colaboram para a criação corporal? Elas estão presentes quando você executa o exercício cênico, você as imagina quando dança?

As imagens colaboram muitíssimo para a alteração dos estados corporais e qualidade dos movimentos. No exercício cênico elas retornam como possibilidade de continuação ou transformação: podemos seguir utilizando nas sequências as imagens que as estimularam, ou transformá-las. Esta relação é muito libertária, pois o desenho do movimento obtém infinitas possibilidades. No caso de mantermos a imagem de inspiração primeira, é interessante, pois a força do movimento se reafirma, o corpo integra-se numa relação afetiva de memória, reencontrando o tônus e a dinâmica da criação. 
6. Durante o processo de pesquisa com a metodologia do Lecoq, você se utilizou das imagens internas (água, terra, fogo, ar, madeira, metal). Como elas influenciaram na execução das sequências de movimento individuais e na criação do exercício cênico? Como você relaciona esses elementos da natureza com a criação artística?

O trabalho com os elementos da natureza me trouxe um reconhecimento destas forças. É um trabalho muito sensível que encontra no corpo e no agir novas dimensões, debruçado sobre a natureza, suas formas e movimentos para aprender com ela, para exaltá-la e reconhecer sua existência integrada em nós. As variações de dinâmicas na natureza são muitas e vêm nos ensinar imensamente, pela grandeza de possiblidades de movimento e intensão.

7. Como você percebe que os elementos, som e luz influenciaram ou modificaram o trabalho, como esses elementos colaboraram?

As texturas sonoras criadas pelo músico Jorge Peña colaboram maravilhosamente para a composição cênica. Assim como as forças das diferentes qualidades de movimento e forma da natureza que inspiraram as coreografias, o som é uma interferência direta e sensível, que influencia cada gesto, desde a emoção até o corpo. A iluminação foi um momento especial de criação conjunta, adentrando as camadas sutis das intenções das cenas e sua correspondência com as atmosferas geradas pelas cores e intensidades da luz. Estes ambientes sensoriais de som e luz permeiam o movimento e adicionam sentido às composições cênicas, atualizando os gestos e detalhes através do diálogo e sensação que geram.

8. Na sua percepção o corpo pode criar sentido a partir dele mesmo? Você acredita que nesse exercício, o corpo revela o sentido e abre caminho para uma percepção mais sensorial?

Sim! Acredito que o corpo cria sentido através dele mesmo. Este exercício provou que o corpo tem memória e uma linguagem própria, muitas vezes desvinculada de uma consciência mental direta. $O$ trabalho de desenvolvimento das composições de movimento nos trazia imagens e dramaturgias por si só, que com o tempo podiam ser lidas e compreendidas por nós. Era como se o corpo fosse um indivíduo com um histórico particular que se apresentava através do movimento e da relação aos estímulos, falando ao seu interlocutor - ele mesmo e nós, que podíamos nos escutar e reconhecer. 


\section{Para você, o que significa o Sentido se Sente com o Corpo?}

O corpo é um campo imenso de consciência e memória. Ele está em relação a todo o universo de uma forma mais completa do que nossa mente pode compreender. O corpo sente tudo, está em conexão com o todo, é capaz das respostas mais espontâneas e instintivas, conjugando o aprendizado formal à evolução animal da espécie. O corpo é cheio de sensação e recordação, e é através destas vivencias que podemos conhecer a emoção, que por sua vez gera aprendizado.

10. Você teria críticas, percepções ou sugestões?

Por enquanto não.

\section{Muito obrigada!!}

Eu que agradeço! 
Questões sobre o exercício cênico: O Sentido se Sente com o Corpo

Respondido por Jorge Peña em fevereiro de 2014.

1. Como foi para você o processo de criação do exercício cênico 0 Sentido se Sente com o Corpo? Quais foram as facilidades e dificuldades?

O processo foi para mim muito inspirador, muitos momentos de silêncios e sempre com muito foco no corpo, na dança, no movimento, na luz, em momento algum encontrei dificuldades mais sim lugar para as novas experiências, novos desafios.

Algo muito inspirador para minha arte das texturas sonoras.

2. Você percebe esse processo como colaborativo, no qual toda a equipe trabalha de forma conjunta? Por quê?

Sim, sempre colaborativo, aberto, deixando sempre momento de pura criação e improvisação.

Luz, som, movimento, criando juntos algo sempre presente.

Por quê? Porque desta forma o trabalho sempre fica mais rico e atualizado, fluido, mágico.

3. Como você percebe o trabalho corporal realizado? Como isso influenciou em seu processo de criação, no caso da textura sonora?

Um trabalho criado com muito foco e com muita dedicação.

A partir do momento no qual os silêncios e a respiração são respeitados como algo fundamental, as texturas sonoras sempre vêm para complementar, para somar, algo muito fluido.

4. Você percebe a influência dos elementos da natureza (fogo, ar, água, terra, madeira e metal) no exercício cênico? Em quais momentos para você isso fica mais claro?

Estes elementos foram os que realmente indicaram o caminho para o som chegar e somar, se envolver, se plasmar junto com a dança e a luz.

Há muitos anos venho desenvolvendo meu trabalho com foco na natureza, elementos, dia, noite, ventos, silêncios. 
Tem muitos momentos que estes elementos estão bem definidos, mas também para meu trabalho das paisagens sonoras não deixo isto sempre claro, óbvio, misturo os momentos e coloco ventos juntos ao som do oceano ou um pássaro junto ao vento, vou costurando com os elementos, mas não reforçando, não fazendo o óbvio e sim deixando aberta a imaginação do público para também complementar o espetáculo.

5. Na criação das texturas sonoras, quais os instrumentos utilizados? Eles se relacionam com os elementos da natureza?

Sim, se relacionam sempre, mas sem reforçar o obvio, deixando o silêncio e a respiração fazer algo como deixar ressoar o movimento sempre conjuntamente com a luz.

Os instrumentos foram vários, mas alguns com uma presença bem maior como os sons de ventos, mar, gongos, pássaros, palmas, voz etc.

6. Como você percebe que os elementos, som e luz, influenciaram ou modificaram o trabalho, como esses elementos colaboraram?

Eles foram introduzidos para valorizar, para dar brilho nos momentos que a dança pedia para que isto acontecesse, reforçar os momentos para ter dialogo com a luz e a dança.

7. O objetivo inicial deste trabalho foi realizar uma criação artística a partir do corpo em cena, do que o corpo poderia gerar de sentido a partir dele mesmo. Você acha que nesse exercício cênico esse objetivo foi alcançado? Como você percebe este aspecto?

Sim, totalmente, os comentários do público não deixam dúvidas de que realmente se alcançou este objetivo.

Para mim, funciona da seguinte maneira, se meu trabalho é inspirador, é porque eu estou sendo inspirado também neste momento. A dança, a luz e o corpo foram muito inspiradores para minha arte poder alcançar momentos de total sutileza e magia.

8. Você percebe, nesse exercício cênico, que o sentido se sente com o corpo? Para você o que significa o Sentido se Sente com o Corpo?

Bom, a gente trabalha muito com o foco nos elementos da natureza e isto é suficiente para trazer todos os sentidos para o trabalho. 
Sentir, respirar, andar, sutilezas, rastros, agora, arte.

\section{Você teria críticas, percepções ou sugestões?}

Somente tenho que agradecer o convite, gracias, gracias, muita luz e vida longa para este trabalho tão lindo e tão focalizado com a proposta do Sentido se Sente com o Corpo.

Muito obrigado! 
Questões sobre o exercício cênico: O Sentido se Sente com o Corpo

Respondido por Rodrigo (Di) Pannacci em fevereiro de 2014.

1. Como foi para você o processo de criação do exercício cênico 0 Sentido se Sente com o Corpo? Quais foram as facilidades e dificuldades?

Acredito que o que facilitou o processo de criação foi $\circ$ fato dos participantes já se conhecerem e possuírem uma sintonia artística. Acompanhei alguns ensaios das intérpretes Kalisy e Sissi, também filmei e fotografei os movimentos que elas criaram. Tudo isso me influenciou na criação da luz. As dificuldades que senti foram o pouco tempo que tivemos para afinar e ensaiar com a luz. Isso gerou uma certa tensão, por estrearmos sem um ensaio em tempo real da apresentação. Mas no final deu tudo certo.

2. Você percebe esse processo como colaborativo, no qual toda a equipe trabalha de forma conjunta? Por quê?

Sim, o processo foi extremamente orgânico, foi impressionante como as partes foram se encaixando e culminaram neste trabalho final. Todos trabalhamos juntos e todos tinham espaço para criar.

3. Como você percebe o trabalho corporal realizado? Como isso influenciou em seu processo de criação, no caso da luz?

O trabalho corporal era extremamente sensitivo, nos levando a conectar a sensibilidade interna, e assim seguir o fluxo dos movimentos com a luz.

4. Você percebe a influência dos elementos da natureza (fogo, ar, água, terra, madeira e metal), no exercício cênico? Em quais momentos, para você, isso fica mais claro?

Em todos os momentos isso fica evidente, a questão dos elementos foi a minha maior influência na criação. Com movimentos mais leves, as intérpretes evocavam os elementos mais sutis, como o ar e a água, levando-me a utilizar cores com frequências mais elevadas como o violeta, o azul e o verde. E nos elementos mais brutos, utilizava frequências mais baixas como o amarelo, laranja e vermelho. 
5. Na criação da luz quais as cores utilizadas? Elas se relacionam com os elementos da natureza?

Sim, se relacionavam quase que diretamente. Percebi que, no geral, o exercício caminhava de sutil para mais denso. Então comecei com o violeta, depois azul, verde, amarelo e por fim o vermelho.

6. Como você percebe que os elementos, som e luz influenciaram ou modificaram o trabalho, como esses elementos colaboraram?

Acredito que o som e a luz não modificaram o trabalho, eles apenas ampliaram a percepção do que já estava ali nos movimentos corporais.

7. O objetivo inicial deste trabalho foi realizar uma criação artística a partir do corpo em cena, do que o corpo poderia gerar de sentido a partir dele mesmo. Você acha que nesse exercício cênico esse objetivo foi alcançado? Como você percebe este aspecto?

Na minha percepção, sim, era bem claro para mim o que os corpos diziam. Não era nada racional, tudo ficava no universo dos sentidos, um universo mais intuitivo, feminino.

8. Você percebe, nesse exercício cênico, que o sentido se sente com 0 corpo? Para você o que significa o Sentido se Sente com o Corpo?

Acho que a melhor maneira de se explicar isso é de uma maneira não verbal. Mas como isto não é possível aqui, tentarei de alguma forma explicar o que sinto. Acredito que o significado do exercício é justamente a ligação com o intuitivo, com nossa percepção não racional. Lembro-me das pessoas ao final da apresentação dizer que sentiam algo que não era possível explicar. Acho que é mais ou menos isso.

\section{Você teria críticas, percepções ou sugestões?}

Para mim, tudo fluiu da melhor maneira possível, apenas gostaria dar continuidade a este lindo e sensível projeto.

\section{Muito obrigada!}

